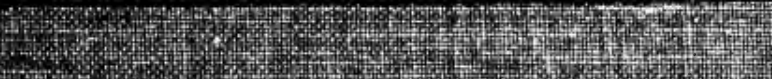

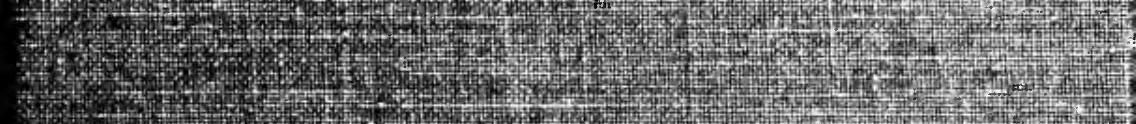

(25. 2.

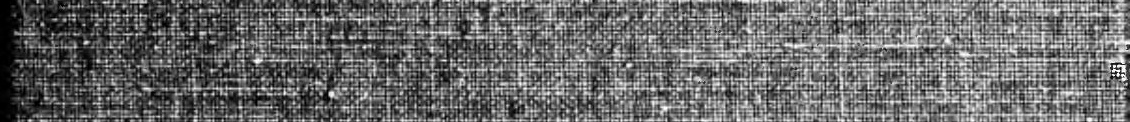

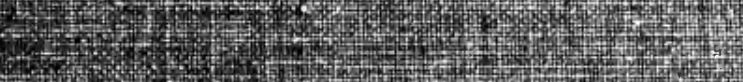
(1) (2)

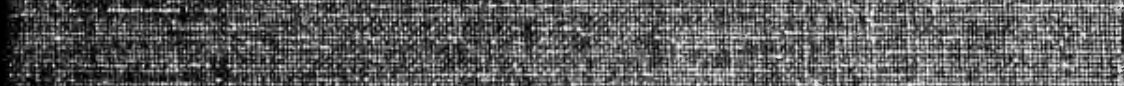

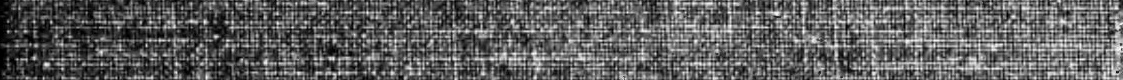
D.

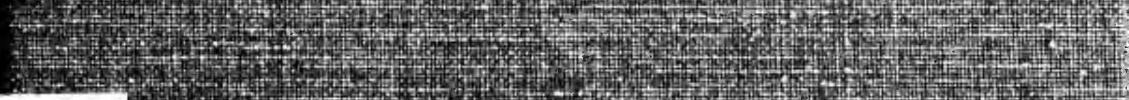
rnia al (1) (1) T. L

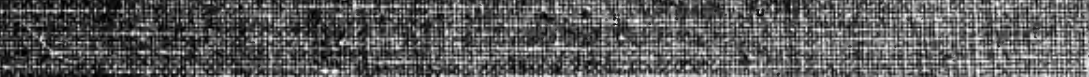

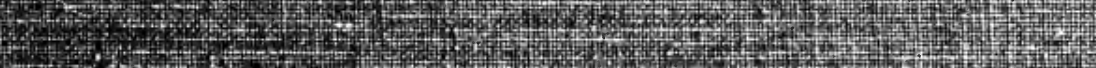

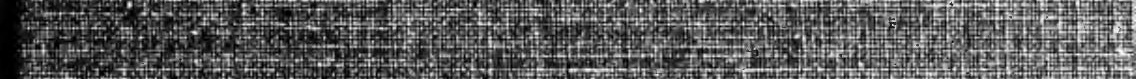

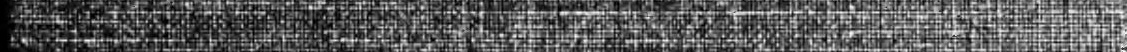
10.0.

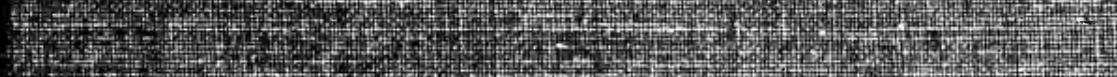

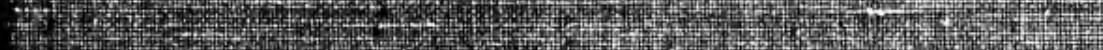
Y 




\section{THE ADOLESCENT GIRL}





\section{T H E \\ Adolescent Girl}

A STUDY FROM THE PSYCHOANALYTIC VIEWPOINT

$\mathrm{BY}$

\section{PHYLLIS BLANCHARD, Ph.D.}

$\triangle$ OTHOB OF "PGYCBOANALTTIC BTUDY OB $\triangle$ COUBTE COMTE"

WITH A PREFACE BY

Dr. G. STANIEY HALL

NEW YORK

MOFFAT, YARD AND COMPANY

1920

$971 \mathrm{~m}$ 
Copyrgite, 1929,

$15 \mathrm{r}$

M(OFAT, Y YGU ANT CONPANY

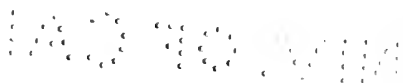

$\because \because \because \because \because \vdots \vdots \cdots$

$\sin \theta$ 


\section{FRHACE}

Dr. Blanchard, the author of this book, was able under unusually favorable conditions to utilize some of the fundamental concepts of psychoanalysis in solving her own adolescent problems, and has since read widely in this field and had interesting and profitable experiences in helping other young women through the perturbations of post-pubertal years. During tho period of my association with her, for the last three years, she has been no less but probably more interested in the philosophical implications of the work inaugurated by the Freudian school, and has been much impressed by Adler and still more by the contributions of Jung. Her life, too, has brought her into more or lesi contact with many young women, some of whom have been and all of whom she believes conld be much helped in the development of sound views of life by wise and careful use of the new sources of light upon the unconscious factors in 
the soul in its last psychical stage of development.

To my own mind the psyche of the budding girl has seemed about the very most unknown of all the great domains of psychology. We do know something, which many years ago I tried to summarize, about this crisis in a boy's life, but the corresponding changes in the soul of the young woman are far more hidden not only to herself but to others. Culture history studies of hysterical phenomena in the wide sense of Pierre Janet have shown the important rôle that these unbalanced souls have played in history from the days of the pythoness at Delphi and the sibyls down to the Fox sisters, who gave the chief momentum to spiritism in this country, and the Creery girls, whose performances were the chief theme of investigation in the early years of the English Psychic Research Society. Many men of eminence have been led far astray from the path of scientific sobriety by adolescent girls, while the "Backfisch" or "tendron" seems to represent perhaps the most generalized type of the human psyche in the world.

The time has now come in the feminist move- 
ment when women should frankly recognize the sex differences in body and mind which they have hitherto so strangely persisted in ignoring. Women are more conservative in body and mind, somewhat more generalized, nearer the race, understand other women better than men understand other men, mature earlier, are more intuitive, etc. They differ widely, too, in their crimes, in their liabilities to disease, their school interests, their outlook upon society and the world. Indeed during the feminist movement of the last generation it almost seems as if the normal influence of woman as such upon the course of events and the lives of men had, to say the least, not increased.

I should like especially to commend this study to the careful attention of all women interested in the true status of their sex in the world. It is probably far harder for women to achieve true self-knowledge than for man to do so. She is more prone either to over- or underestimate herself or to take flight from reality and to misconceive what she really wants. It is because a true knowledge of 
woman, as of man, must begin if it does not end in the study of the teens, when nature is trying to add a new and higher story to our being, that I am glad of an opportmity to very heartily commend this book to the attention of all who at this crisis in her history, when woman has so suddenly attained so much, are now asking what is the next step.

G. Stanley Hall.

Clark University,

January 1, 1920. 


\section{FOREWORD}

The changes in social customs and institution: which have come about as a result of the upheaval created by the World War have brought to woman new duties and grave responsibilities It is for the wise and efficient carrying out of these that the adolescent girl must prepare herself, for no sudden inspiration can be trusted to guide her when they fall to her lot; she must have a firm, sure knowledge of herself and of her place within the cosmic order if she is to use aright the power which is being placed in her hands. With the entrance of woman into worlit politics, a new psychic force becomes active within the life of the group, an emotional and idealistic energy which has vast potentialities for the future of the race. In order to make this dynamic force a potent factor in the creation of a better society, it must be guided and controlled by a clear intelligence and an accurate knowledge of all that it can mean for ix 
human weal or woe. It is to provide the adolescent girl with definite information concerning her own nature and the powers that are latent within it, and to point the way to a proper utilization of her energies, that this book has heen written. It is given to her in the hope that it may offer certain suggestions which will enable her to analyze and understand her own individual personality, so that she may be better able to find her own unique place in the world, and to make her own peculiar contribution to the larger life of the group of which she is a member.

It is fitting that I should at this point express my gratitude to the many friends who have helped me in the preparation of this manuscript through their sympathetic interest and hearty coöperation in the gathering of original material. Especially do I wish to acknowledge my indebtedness to Dr. George E. Partridge for his keen criticisms and helpful suggestions; to Mrs. Iva L. Peters, Ph.D., for the use of data collected in the course of her intimate association with adolescent girls; to those girls, my friends and others whom I have never seen, who have 
unsparingly lain bare their inner lives in order that other girls might be helped to attain a more complete understanding of their feelings and impulses; and, most of all, to Pres. G. Stanley Hall of Clark University, without whose unerring insight and patient encouragement this book would never have been written.

\section{Phyllis Blanchard.}

Clark University, Worcester, Mass.

January 1, 1920. 



\section{CONTENTS}

CHAPTER

PAGE

Preface by G. Stanley Hall . . . . . V

AUTHOR's FOREWORD . . . . . . . . ix

I. The Broader VIEW . . . . . . 13

Conception of woman as a mysterious being; Iuefinition of adolescence; Philosophical background of the genetic viewpoint:-Fichte's universal will, Schelling's evolutionary interpretation, Schopenhauer's will to live. Von Hartmann's uncemscious, Bergson's élan vital, Freud's theory of the libido, Trotter's view of repression, Adlerian will to poucer, genetic viewpoint of Jung, Macder's statement of the significance of the unconscious in human life; Application of this philosophical and psychological principle to the adolescent girl.

II. The Sexual and Maternal Instincts OF THE Adolescent Girl . . . . .

Physiological background: Giggling as a method of attracting the attention of the opposite sex; Adolescent love of dress; Reveries concerning death; Suicide of adolescent girls; Inve fetishes; Love for older persons; Female periodicity of the sexual impulse; Individual differences in croticism; Dream-life of adolescent girls:-Symbolis dreams, sexual dreants; The masochistic tendency; Selfanalyses of some adolescent girls:--Sexual life, day-dreans, etc.; Tendency of sexual tension to pass over into other forms of emotion; Indications of the miternal instinct.

III. Tine Adolescent Conflict . . . .

Origin of individualistic impulses: Will to power; Factors which reinforce will to power in adolescent girls; Hlustrative cases; Freudian interpretation of the conflict; Cases which illustrate the conflict between the will to power and the racial impulses; Feminism and the masculine protest; The real adolescent contlict. 
Man more sexual than other animals; Religious and social repressive factors; Vicarious efferent outlets for sex tension; Scott on sublimation; Don Marquis' poem; Significance of sublimation for adolescence; Pedagogical apolications; The rôle of sublimation in the solution of the adolescent conflict.

\section{Pathological Manifestations of Libido in Adolescent Girls}

Hysteria-Freudian statement; Healey on delinquency of hysterical girls; Mediumship in adolescent girls; G. Stanley Hall's study of a budding medium; Dissociated personality; Pathological lying; Religious forms of hysteria; Hauptmann's Hannele and St. Theresa; Jung's theory of Dementia Præcox; Case study of D. P. by Dr. Lucile Dooley; Borderline cases; Therapeutic measures.

\section{The Adolescent Girl and Love . .}

Love the center of girlish reveries; Scientific studies of love:-Composite sentiment, mere sexual passion outgrowth of the sense of touch; Finck's conception of romantic love; Views of Carpenter and Mantegazza; Inadequacy of these scientific formulæ; Philosophical theories of love:-Empedocles, Judah Leo, Plato, Schopenhauer; View of Renooz; Metabolic basis of sex attraction; Weiniger's male and female plasm; Blair Bell's sex complex; Pearson's statjstical studies; Psychomalytic view of compensation through love; New ideal of love and the adolescent girl.

\section{The Adolescent Girl and Her Future}

Varied rôle of woman during the war; Effect of the war on sex relationships:- Raping of conquered women; War brides, illegitimacy; Attitude of the American girl to the soldier; Results of the lowering of sexual morality on society and on the young girl; Effect of war on the political status of woman; Position of woman in the social scheme:-Schoonmaker's conception, Kidd's vision of woman as the embodiment of love, Madeline Doty's summary of what she has done; Responsilility which rests on the adolescent girl; New feminine art and literature needad; 'The religious belief for the adolescent girl:Nicolai's interpretation of Christianity as a cosmic humanism. 


\section{THE \\ ADOLESCENT GIRL}

\section{CHAPTER I}

\section{THE BROADER VIEW}

Conception of woman as a mysterious being; Definition of adolescence; Philosophical background of the genetic viewpoint:-Fichte's universal will, Schelling's evolutionary interpretation, Schopenhauer's will-to-live, Von Hartmann's unconscious, Bergson's élan vital, Frend's theory of the libido, Trotter's view of repression, Adlerian will to power, genetic viewpoint of Jung, Maeder's statement of the significance of the unconscious in human life; Application of this psychological and philosophical prineiple to the adolescent girl.

Through long ages of painfully slow progress, man has solved, one by one, the secrets of the universe, and has turned this knowledge, gained with infinite labor, to his own advantage, reshaping his natural environment to suit his needs. Yet for all his diligence, there have 
been a few riddles to whicb he conld not find the answer, but which have so piqued his curiosity that they have been the center of his speculations ever since there came a lessening in the struggle for existence which permitted him to wo his energies in abstract thought. One of the most tantalizing problems is woman, because she has remained a baffling mystery, as is shown by the folklore and literature of every people at every level of culture, in spite of her intimate relationship to man and the commonplaceness of her existence. In the attempt man has made to fathom her soul, she has been deified or endowed with demonic powers as the case may be.

Not until the present century, when the steady hand of science has brushed away the clinging veils of superstition, has there been any attempt at approach from a rationalistic viewpoint, and even now we are hampered by the weight of old traditions so that our findings have been more or less colored by ancient attitudes and old habits of thought. Yet slonly and surely, the sum total of our knowledge is increasing, so that to-day we can at least de- 
scribe the psychic processes of the feminine mind with some degree of accuracy, and advance more or less pertinent theories to explain its reactions.

At no time of her life is the soul of woman more complex than during the period of her adolescence, when she is swayed hither and thither by sensations and emotions utterly foreign to her previous experience, and responds to these new stimulations in a manner no less inexplicable to herself than to the casual ob. server. So strange, indeed, has been her conduct at this time that she has excited the interest and attention of all peoples. The savage races regarded her as possessed of supernatural powers and imbued with spiritistic forces, which they tried to exercise or appeasn by an elaborate system of rites and rituals known as initiation ceremonies, and from thr influence of which they sought to protect themselves by isolating the pubescent girl and surrounding her with an intricate system of prohibitions and taboos. (10.) No less unreasoning was the attitude of the Middle Ages, as expressed in the witchcraft persecutions, which 
persisted in sporadic outbreaks well into later history.

The modern scientific approach, which regards adolescence as a purely physiological phenomenon, based entirely on metabolic processes within the organism, is correct as far as it goes, but its grasp is too limited, its scope too narrow, to reach the heart of the problem. Only to those scientists gifted with a rare combination of psychological insight and philosophical breadth of vision is vouchsafed the ability to plumb the depths of the young girl's inner life. G. Stanley Hall has best formulated the fundamental principle which is essential for the proper understanding of adolescence, and which may be briefly stated as follows:

The phenomenon of adolescence is to be understood only as it is conceived as the entrance of the individual into the larger life of the race, so that the psyche reverberates with old phyletic memories lying deep within the nerve plexuses and ganglia of the subconscious, far below the level of consciousness; feels the impulsion of irresistible forces which urge the 
boy or girl to express in their own person the myriad activities which have characterised the stirp in the long æons of its development; and is flushed with that mighty creative energy which has forced the living organism to ever higher forms of existence, and now impels the adolescent to be and do all things in his own person.

This conception of adolescence, which has its best illustration in the pubescent girl, was not reached in a single bound, but is the final out. come of a long series of transitions in the progress of human thought. If we are to under stand its full significance, therefore, we must trace its development from its first faint inception to its final expression in the psychological and philosophical teachings of the present day. In order to accomplish this purpose, it is necessary to make an abrupt break in the continuity of our thought at this point, and digressing from our main theme of the adolescent girl, to go back into the history of philosophy and give a brief discussion of the development of the evolutionary theory and the psychology of the unconscious. 
The genetic viewpoint has been evolved through a maze of philosophical wanderings, and is the culmination of a train of thought started by Fichte when he departed from the idea of a universal substance which had so long obsessed the human mind, and postulated all life as a vitalistic, dynamic process, struggling to attain ever higher planes of existence. Heraclitus and other ancient Greek thinkers had dimly foreshadowed this conception in their descriptions of an ever-changing universe, but their theories could scarcely be classed as evolutionary, since their world-process was a static condition, involving no developmental tendency, or inclination to progress.

Tc Fichte, then, belongs the honor of formulating the hypothesis of an untiring, impelling force underlying all existence, an hypothesis which has been a constant source of controversy between the later vitalistic and mechanistic schools of philosophy. But his contribution, while important as a starting point for his successors, was of little value in itself, for his thinking was hampered by the old metaphysical problem of freedom of clioice, so that he fash- 
ioned his whole philosophical system around the central statement that man is a free and independent being, acting entirely by his own volition.

This fantasy of the omnipotence of the will, in which Fichte sought to escape the harsh realities of his daily life, became for him a veri. table obsession, so that he postulated his great life force, his motivating energy, as pure absolute will, which finds partial expression in the lives and wills of finite beings. To the finite human will is given the power to choose for itself whether it will work in accord with the infinite moral purpose whence it sprang, or follow devious paths of wickedness which permeate the world order, and delay the attainment of a state of complete perfection. But although the ability to thus choose is freely vouchsafed to man, the resistance of the outer material world is never wholly overcome by the strivings of humanity, the universal moral purpose is never fully realized, and world succeeds world in the never-ending struggle which does not realize its utter hopelessness, but is driven on continuously by that irresistible and 
eternal energy which is the source and life and end of all things, - the infinite will.

In Schelling's philosophical system, this universal will received a pantheistic setting and became the force which pervades all nature, both inorganic and organic, as well as the essence of human life and being. For this broader view, the cosmic energy of which Fichte saw only the voluntaristic side is conceived as a living, creative, purposive principle of evolution, which moves from unconsciousness to consciousness, and has for its ultimate goal the self-conscious psychic life of man. In living beings, this evolutionary process moves onward from the organism capable only of rudimentary sensation through instinct to intelligence and creative imagination.

The highest stage of its expression is reached in creative artistic work; the artist imitates the creative principle of the universe, and in so doing becomes conscious of its presence within his own life. Only through such intellectual intuition as this can man become aware of the existence of the living, moving element of nature; the use of reason alone will never demon- 
strate its existence. Thus not voluntary morality, as Fichte held, but artistic intuition becomes the most harmonious coördination of the individual with the absolute will-force. Herein, as we shall see later, Schelling made an important advance over Fichte, and in a sense prophesied, however vaguely, one of the principles to be established more than fifty years after the philosopher's death by a new science -Psychoanalysis.

The deification of the will begun by Fichte was carried to an even greater extreme by Schopenhauer, in his attempt to present a detailed analysis of the universal energy which permeates all existence. Instead of two opposing worlds of force and matter, Schopenhauer, like Schelling, conceives of will as the vital essence of all things, a subjective realit which objectifies itself in the material worli of our sense perception. This will-energy is expressed as a blind force in the inorganic world, but becomes conscious of its existence in the living organism. In the latter manifestation it is to be distinguished from its other forms by being conceived as the will-to-live of 
the individual, which determines the structural characteristics of the lower forms of life in harmony with its desires, and creates the intellectual faculties to serve its purpose in man.

In the objective world, we see the result of the craving of these various wills for visible expression in the bitter struggle for existence, in which each strives to survive at the expense of the others; but since all will is equally immortal, only individuals are destroyed; the species, or will-type, cannot be annihilated. Thus, while the individual will-to-live guides the manner of growth and the life-perserving activities of the organism, there is a higher power which ınay be expressed in activities directly detrimental to the individual through whom it is manifested. The most common illustration is the blind in palse of sox, which viten results in individual unhappiness or even destruction, in direct negation to the life impulse, but which subserves the more powerful will-to-live of the race. And so we advance a step beyond Fichte's teaching that man is a free and independent being, and find that he is governed by fimpulses beyond his understanding and con- 
trol, which are the visible expression of the great racial will-to-live, of which he is but an infinitesimal portion.

To the idea of will as the ultimate basis of an adequate conception of the great mystery of existence, Edouard von Hartmann adds another element which entitles him to be considered of utmost importance as a link in the chain of thought which has its climax in the modern genetic philosophy, with its conception of the Unconscious. It is, indeed, necessary to assume the operation of a will in nature, but this will must be conceived as unconscious, although at the same time it is intelligent and working toward some logical end. Yet it is to be emphasized that the end itself, while apparently purposely sought by the organism, is never consciously recognized in the course of the elaborate series of adaptations which lead to its final accomplishment. As for matter, it consists simply of centers of force, or unconscious will-impulses, which represent the activities of the absolute, universal will. This infinite force luas in it an element of reason, so that the world will expresses itself in a rationa: 
and orderly purpose of evolution. This insistence on the importance of the unconscious factors of life was a significant addition to human thought, but it remained for von Hartmann's successors to enlarge this doctrine and place it upon a firm empirical basis.

Although somewhat reminiscent of the German philosophy of the will as outlined above, Henri Bergson is equally worthy of consideration, for his is the modern evolutionary philosophy par excellence. Although he is absolutely opposed to the mechanistic school, he has gone far beyond the teachings of other vitalists in giving us the doctrine of creative evolution, and in his insistence upon the validity of intuitional conclusions as opposed to purely intellectual deductions. Whether we can find any logical evidence or not, according to Bergson we are safe in trusting the intuition which tells us that there is an original life impetus, which passes from one generation of germ plasm to the next through the organisms which bridge the intervals between generations. Life itself is an unceasing creation; the life force, or élan vital, which was homogeneous in the beginning, 
tends to differentiate into varying forms, which are not in accord with any preconceived purpose, but are created in the very course of the evolutionary process.

There have been developed three chief modes of expression for this blind, creative impulse; the condition of torpor, which is characteristic of the plant world; the instinctive life of the lower organisms, which culminates in the hymenoptera; and the intelligent existence of higher animals, which is at its best in mankind. The manner in which this élan vital finds expression is of little import, however ; the essential thing is the fact that there runs through every living organism a vital current, which is hardly evident except as it occasionally becomes visible in works of genius, but which is the a smimating force of the individual, and is passed on continuously from one generation to the next.

The last stage in the train of philosophical thought which culminated in the genetic concept briefly stated at the beginning of this chapter was the development of a new branch of psychology known as psychoanalysis, which 
was begun by Frend and Adler, and placed on a broad evolutionary basis by Jung and Maeder. Sigmund Freud, the originator of the new psychology, 1 .is the first scientist to make extensive use of the idea of thr subconscious introduced by von Hartmann. In his analyses of neurotic patients, Dr. Freud discovered that almost invariably the main cause of the psychic derangement was a suppressed sexual impulse, which, to use his phraseology, had become displaced from the conscious to the subconscious strata of the nervous system. A little later, his studies led him to believe that the genius was likewise inspired by this unconscious sexual energy, which had been denied expression in its primitive biological form.

In accordance with the empirical data thus established, Dr. Freud formulated his theory of the libido, which is the simple statement that the motivating principle of all human activity is the procreative instinct, which in its broadest interpretation is better termed libido, since it includes a wide range of activities not commonly classed under the sexual impulse proper. When suppressed, or denied the opportunity of 
discharge through its primary outlet of sexual intercourse, the energy of the libido is normally transmuted into higher nervous processes, and transversing neural pathways of association, reinforces the rsthetic creative impulses, and spurs the artist to his best endeavors. This process is known as enblimation in the psychoanalytic terminolgy. When it fails, the libido seeks pathological efferent pathways, and utilizes its energy in weaving day-dreams and illusions around its frustrated desires, or becoming converted downwards, produces the physical symptoms of hysteria and other neurotic disturbances. In either case, whether it seeks a higher or lower outlet, the process takes place wholly outside the range of conscious recognition or control, and hence the r.1.01 scious becomes the dominant factor of human life.

According to Freud, the sexual desires are displaced from consciousness because they are so often not in complete accord with conventional moral standards. The mind has come to exercise a function of censorship which allows only those thoughts and wishes which are in 
harmony with the contemporary social code to enter consciousness, but because the moral standards are continually being modified, they never have more than a superficial place in the psyche, and hence the dominance of the unconscious motives, which triumph over conscious morality by entering into behavior or into thought in disguise, as symbolic acts and imagery.

It remained for Trotter, an English psychologist, to realize that the Freudian "censor" had a foundation as deep as that of any other mental mechanism, since it rooted in the gregarious or herd instinct. It is the gregarious impulse, the longing to be like one's fellows, and to do as they do, which impels the acceptance of social customs even though they be not entirely in harmony with other cravings.

In this sense, repression is not a peculiar property of the psyche, a kind of new faculty of the mind, but is the inhibition of one instinctive desire by another equally powerful and fundamental.

Influenced by the Nietzschean dogma of the will to power, Alfred Adler broke away from 
the teachings of the Freudian school, of which he was originally a member, and attempted to establish the Ichtrieb, or Wille zur Macht, as the root of unconscious cerebration. In Adler's estimation, the libido, or racial instinct is quite overshadowed by the egoistic impulses which had their primordial source in the instinct of self-preservation, and are manifested in man through an inordinate craving for power. The physiological basis which determines the strength of this desire in the individual is defective organic structure, which retards processes of adaptation, and creates a feeling of inferiority and inability to meet the struggle for existence, for which the sufferer tries to compensate by increasing the quality of his higher psychic processes. In its extreme form, this produces the intellectual genius, who thus receives his impetus from his physical weaknesses; but it also produces the neurotic, who takes refuge from the hardships which are too stern for his impaired organism in a world of fantasy or uses his weakness to obtain control of his associates, who dare not refuse his most outrageous requests lest they upset his delicate 
nervous mechanism, and precipitate a final breakdowil. And so the famous flight from reality first described by Freud, becomes an attempt to satisfy the dream of power, instead of the creation of an illusion of a happy lovelife.

These opposing views of Freud and Adler were finally adjusted by the synthetic genius of Jung, who demanded an enlargement of the concept of the libido to include the sum total of human activities, so that it becomes synonymous with the Bergsonian élan vital. (6.) From this viewpoint, the sexual and social instincts, and the individualistic impulses, whether manifested as the simple instinct of self-preservation' or in the will to power, are only two different forms of the same life energy, and the neurotic diathesis is the result of a struggle between the two motives for simultaneous expression. As one or the other principle becomes the dominant factor in a personality, we have the racial or feeling type, who is technically known as the extrovert, and the egoistic or thinking type, who is styled an introvert. The great artists have always belonged to the 
former class, while the intellectual genius is inevitably an introvert. (5.) In the normal personality, the two functions are fairly well balanced, so that first one and then the other predominates, but neither succeeds in excluding the other from consciousness, and relegating it overlong to the unconscious levels of the psyche.

Besides the unconscious phenomena describec by Freud, which consist essentially of repressed wishes and old childhood memories, Jung postulates an absolute subconscious which consists of old phyletic memories and impulses deeply ingrained within the more primitive layers of neural tissue which precedest the central nervous system in phylogenetic development. The echoes from these pri val memory traces reverberate through the higher nerve centers, and give rise to feelings and emotions wholly foreign to the experience of the individual, but, which have been of vital issue to the stirp in its struggle for survival. There has always been a tendency to project these mysterious feeling-tones upon some external object, and to endow that object with supernal powers, con- 
ceiving it as the cause of these indefinable emotions. In this manner the libido or élan vital, or hormé, stirring within the depths of the absolute subconscious, has created the folklore, mythology and religions of all peoples.

Accepting Jung's interpretation unreservedly, Alphonse Macder fuxther points out that in the disregarc of these unconscious forces in human nature lies the great error of the intellectualistic and mechanistic philosophy of our scientific era. There is no sure guide for human destiny except the intuitive impulses of the unconscious, which are but a psychic manifestation of the creative and regenerative principle in nature. In yielding to these motives we are obeying the great cosmic force which created all life, from the lowliest bit of protoplasm to the highest intellectual or artistic genius; which gave to the lower organisms the power to regenerate lost parts as it gave to man the innate tendency to resist disease. The assimilative property of the cell, its power to change inorganic substances into its own living material, is the nearest approach to this life principle on the biological side. Its primordial psychic 
manifestation was the creation of mythology and religion in the early days of the race. Modern man must also learn to understand and follow this intuitive guidance of his unconscious, not blindly, but intelligently in the clear light of his scientific knowledge. In no other direction lies the ultimate salvation of humanity; without such guidance other cataclysms like the recent war will inevitably ensue, man will fall short of the possibilities within the limits of his attainment, and the great evolutionary principle will have to begin anew the creation of a higher race of beings.

The insight acquired through this series of philosophical studies enables us to evolve certain fundamental principles for our guidance through the labyrinth of the young girl's sorl. As we have seen, the vital element of all existence is an irreducible, irresistible energy-call it libido, élan vital, hormé, will-to-live, what you will-which animates the organism and shapes its acts to suit its inscrutable purposes. It is not always favorable to the existence of the individual, to be sure, yet to it he owes his very life and being, since he exists for the sole pur- 
pose of insuring its continuity and receives whatever spark of genius dwells within him from its exuberant energy. It is a wholly unconscious force, obscure in all its activities, but apparent in the otherwise inexplicable phenomena to which it gives rise.

With the maturity of certain functions through whieh it has long found a favorable means of expression, this vital force engulfs the individual in its mighty current and sweeps him along with its overwhelming power. The adolescent is experiencing its full strength in his own person for the first time, henee the storm and stress of this period of life. The adolescent girl is unduly sensitive to this strange force within her being, beeause to her; much more than to her brother, is given the serious mission of transmitting it intact to succeeding generations. Benjamin Kidd recognizes this when he asserts that her high calling of motherhood has made of woman a being utterly unlike man, in that she is capable of far greater self-sacrifice and altruism than he, has developed to a remarkable degree the ability to refuse present pleasures in the interest of 
future racial welfare, and has a measureless capacity for long-circuiting her emotions which. it would be well for man to emulate. Indeed, Kidd goes so far as to demand that woman be given control of human affairs, that the world may henceforth be ruled by all-embracing love and unselfish devotion. (\%.)

At first glance, this view may seem extreme, but as we examine it more closely, and grasp its full meaning, we are forced to the conclusion that after all it is quite correct, and that woman is indeed the living embodiment of the racial and altruistic forms of the libido or élan vital, just as man is the expression of the individualistic forces, or will to power. The life of woman is essentially a life of service; slic lives not for herself, but for the comfort and welfare of her mate and offspring, or casts herself into the maelstrom of social and political affairs in order to make the world a better and safer dwelling place for its children. It is this tender sympathy which has made her figure in history as the eternal mother, and has moved man to worship at the shrine of the Madonna, 
who is the glorified symbol of all that woman stands for in the course of human destiny.

Being thus preëminently the generic being, it is only natural that woman should have a larger unconscious life than man, for the egoistic impulses enter the field of consciousness more readily than the less obvious racial and social instincts. That this is indeed the case, is indicated by the proportionately greater sympathetic nervous system of woman, and by the fact that she achieves her decisions with a rapidity far beyond the slower reasoning faculties of man, by means of her so-called intuitive processes, which are nothing more than unconscious reactions, which take place without her realization or volition.

The incontrovertible proof of her subordination of self to the welfare of the group, is the fact that upon woman the function of transmitting the torch of life falls with incredible severity, so that she suffers all things in her own person in order that the race may endure. Nor does her self-sacrifice end with the great act of child-bearing; for thenceforth she renounces her own individuality, and lives only 
in the life of her offspring, tending them with supreme devotion, utterly oblivious to the personal discomforts and renunciations which they entail. The accomplishment of man's share in the procreative act, on the other hand, not only involves no sacrifice, but is intimately connected with his own pleasure, and is thus in entire harmony with his egoistic tendencies. Indeed, under the existing social conditions, he is apt to sacrifice others in his unheeding obedience to the great sexual impetus.

Only under the tension of some momentous event, some supreme crisis, does man give himself over to the altruistic impulses, and follow them even at the risk of his own happiness and of life itself. No better illustration of this could be found than the great World War, in which the men of all countries, threatened with national destruction, felt the gregarious instinct rise paramount to individualistic considerations, for the mome' $i$, and performed feats of the utmost herois', with no thought of self and no fear of a deain which seemed inevitable. Yet this unswerving courage and utter willingness to give one's life blood for the welfare of 
the social group, is the universal characteristic of womankind; the braving of death for the sake of the race is an everyday occurrence to her, since it is concomitant with the biological function of motherhood.

It becomes evident that Jung might well have carried his philosophy a step farther, and designated woman as the Freudian or feeling type, and man as the Adlerian or power type. And he might also have said that the supreme struggle between these two principles of human conduct takes place at adolescence, which cannot be adequately explained upon any other basis. The struggle is more profound in the girl than in the boy, because she must learn to achieve complete subordination of the egocentric tendencies which have been the sole guide of her conduct up to this time. The boy, on the other hand, after a brief period in which his emotional life is flushed with this new impulse to serve his fellows, returus to a great extent to his old condition of egoism and self-aggrandisement. It is the intensity of this struggle and the enormous difficulty of entirely achieving her goal, which has stamped woman with a greater 
taint of neuroticism than man; when the war brought to him the same problem of self-immolation, he, too, succumbed to the curse of neurosis, as a result of his inability to accomplish this end.

The existing economic and social order has made it increasingly hard for woman to attain the full development of her ultimate nature, for in many eases, the absorbing task of marriage and motherhood which originally fulfilled her organic needs has been denied. There has been a proportionate increase of neuroticism as one result of this condition, but a different method of meeting the problem has been the enlargement of the sphere of woman's activities which has permitted her to express her tender impulses in service to mankind instead of in her own restricted family circle, so that she gains in broadness of scope what she loses in intensity of feeling. A third solution, the entrance of woman into the field of economic competition, has tended to hinder her yielding of her being to the clamoring feelings and emotions which assert their just claim to her organism, and to overemphasize the individualistic 
side of her nature. Hence she has evolved the social philosophy of feminism, and is demanding economic independence and political equality with man in order that she may have ample opportunity for self-development.

The true feminism is an entirely different product, and is based on the assumption that woman has a right to demand that she be assured adequate expression of her love and sympathy, whether in the family circle or in the mothering of mankind, and that she be permitted a voice in the shaping of world affairs for the welfare of society and of the race. It is inconceivable that so legitimate a request can be long denied; the question is, will woman be prepared to use this new power when it shall be placed in her keeping? And the answer depends upon the adolescent girl and whether she succeeds in passing through her great crisis sanely and normally, to emerge from the years of her probation a true woman, strengthened by the bitter conflict which she has undergone, and ready to cast aside all thought of self in the interests of humanity and of the race. In this direction, too, her own 
personal happiness lies. Only as she gives herself over unreservedly to these deeper motives of her physiological and psychological makeup, or as Maeder would phrase it, only as she obeys the intuitive guidance of the unconscious, can she find herself truly in harmony with the fundamental laws of the great cosmic process.

\section{BIBLIOGRAPHY FOR CHAPTER I}

1. Adler, Alfred. The Neurotic Constitution. $456 \mathrm{pp}$. Moffat, Yard. N. Y., 1917.

2. Bergson, Henri. Creative Evolution. $407 \mathrm{pp}$. Holt. N. Y., 1911.

3. Freud, Sigmund. Three Contributions to the Sexual Theory. 91 pp. Jour. Nerv. \& Ment. Disease Pub. Co. N. Y., 1910.

4. Hall, G. Stanley. Adolescence. 2 vols. Appleton. N. Y., 1904.

5. Jung, Carl G. Die Psychologie der Unbewussten Prozesse. 135 pp. Raseher \& Cie. Zürich, 1917.

6. Collected Papers on Analytical Psychology. 492 pp. Moffat, Yard. N. Y., 1917.

7. Kidd, Benjamin. The Science of Power. 306 pp. Methuen. London, 1918.

8. Maeder, Alphonse. Guérison et Evolution dans la Vie de l'Ame. 70 pp. Rascher \& Cie. Zürich, 1918. 9. Trotter, W. Instincts of the Herd in Peace and War. 212 pp. Unwin: London, 1916.

10. Van Waters, Miriam. The Adoleseent Girl Among Primitive Peoples. Jour. Relig. Psy. VI, 4, Oct., 1913, pp. 375-421; VII, 1, Jan., 1914, pp. 75-120. 


\section{CHAPTER II}

THE SEXUAL AND MATERNAL INSTINCTS OF THE ADOLESCENT GIRL,

Physiological background; Giggling as a method of attracting the attention of the opposite sex; Adolescent love of dress; Reveries concerning death; Suicide of adolescent girls; Love fetishes; Love for older persons; Female periodicity of the sexual impulse; Individual differences in eroticism; Dream-life of adolescent girls:-Symbolic dreams, sexual dreams; The masochistic tendency; Seli-analyses of some adolescent girls: Sexual life, day-dreams, ete.; Tendency of sexual tension to pass over into other forms of cmotion; Indieations of the maternal instinct.

While Jung was of sufficiently philosophical turn of mind to enable him to develop the hypothesis of a great evolutionary force of life and the theory of the unconscious to the fullest extent, he was at the same time too much the scientist to negiect the fact that the vital impulse has a somatic as well as a psychic side. We find, therefore, that he describes the organ- 
ism as equipped with an infinite variety of physical structures, the functioning of which is the physiological mechanism through which the élan vital, or libido, finds an outlet in manifold activities. The first expression is an entirely selfish one, and is the desire for nutrition which is manifested through the motor reflex of sucking in the human infant. (19.)

In its broadest and most inclusive interpretation, this hunger-motif becomes one of the two great dominating factors in the existence of mankind; the other is the sexual impulse, which, although the Freudians have demonstrated its activities at an exceedingly early age (12), attains its full significance only at the critical period of adolescence, which is, in a sense, a rebirth of the individual, since with its advent, there must be made readjustments almost as radical as those attending the transition from the pre-natal state to the external world. It follows that if we are to make an intelligent study of the adolescent girl, we must know something of the manner in which this second motive is manifested in her feelings and conduct, a knowledge which can be gained only 
by a concrete analysis of her erotic life in all its phases.

The most obvious physiological phenomena which characterize the onset of puberty in the female sex are the establishment of the periodic menstrual flow, and the rapid development of the mammary glands and other secondary sexual characters $(26 ; 30)$. Besides these, there is a less apparent but equally important change in the whole body metabolism, for as Blair Bell has shown, it is not merely the reproductive organs and their hormones which control the physical manifestations of sexuality, but all the glands of internal secretion, acting together, which determine the erotic life of the individual. Bell concludes that before adolescence, there is very little difference between the metabolic processes of the male and female organisms; but at that period, the endocritic glands, interacting harmoniously by means of mutual control through the hormones which are produced by them, form a metabolic synthesis which may well be termed the sex complex and thus determine the degree of masculinity or femininity. (1.) 
There are thus seen to be two types of phenomena which compose the physiological side of adolescence: the specific sexual stimuli from the pressure of internal secretions formed within the reproductive glands proper, and a general change of feeling-tone which is conditioned by the functioning of the other glands of internal secretion. This second factor is not at all of a strictly sexual nature, but as Cannon (4) and Crile ( $r$ ) have shown, is the common metabolic background characteristic of all powerful emotions, whether of fear, anger or sex.

In the case of the adolescent girl the emotional state is of undoubted sexual origin, and is probably produced in response to hormone secretions from the ovaries, which stimulate the other endocritic glands to activity. It is the general sensations from this increased endocritic functioning which produce the affective changes in the mental life of the adolescent girl, since in her case there is no direct source of constant stimulation such as that furnished by the accumulation of spermatic fluid in the male. Moreover, this emotional energy does not require a specifically sexual outlet, for by its very 
metabolic nature, it is readily capable of passing over into some other emotion, such as anger, fear or religious ecstasy. However lightened may be her task of self-control on this account, the adolescent girl has nevertheless entered upon the definitely sexual phase of her existence, a phase which Dr. Frink has very well characterised in these words:

"Sexual emotion, tension, or preparedness is less dependent on external situation than are other normal emotions. We do not feel continual normal anger or fear unless we are continuously subject to an external menace. But sexual tension, or preparedness, may arise in the absence of any external stimulation, and tends to persist until relieved by some suitable action, of which coitus, in the adult, is normally the most satisfactory one. Thus, in the absence of actions adequate in quality or in frequency to discharge the libido, there may come about a state of organic sexual preparedness which is chronic. (This does not mean that the individual need be continuously aware of sexual desire.) In other words, a lack of adequate. sexual outlet (and by this is not meant simpiy 
abstinence from intercourse) may result in the accumulation in the blood of abnormal quantities of thyroid bodies, and perhaps of sugar, adrenin, and other substances which constitute also an important part of the state of preparedness for non-sexual exertion, such as attack or flight, and this very likely is accompanied by corresponding changes in the sympatheticautonomic balance." (13: pp. 258-259.)

Correlated with this increased metabolic activity, there is an augmented sensibility of afferent nerves and end-organs, both visceral and peripheral (15: $p p$. $37-38$ ), and it is upon the basis of this organic instability and readiness for reaction that we can best explain the conduct of the pubescent girl. Through all her seeming inconsistencies, she is seeking an outlet for the great reproductive energy which has thus taken possession of her being, and this motive, taken into consideration with the increased sensitivity of the afferent nervous system and the consequent exaggeration of motor response, furnishes the key for a right interpretation of her demeanor. 
The first evidences of the awakening vita sexualis in the young girl is an inordinate desire to attract attention from the opposite sex. Who has not observed the various ways in which the high school girl, while not admitting her motive even to herself, endeavors to draw the regard of her male companions? Incessant giggling seems to be a veritable disease with her, and although partly due to her new consciousness of sexual differences, and the tension of meeting social situations for which she as yet feels herself lacking in poise, it has also the nlterior purpose of attracting the glances of those erstwhile everyday comrades who are now surrounded by the glamour and fascination of their masculinity.

In addition to these causes for the epidemic of giggling, G. Stanley Hall notes a more useful function, in that it forms one extreme of the hedonic scale whereon the emotions play up and down, in preparation for the joys and sorrows which must be experienced later, in contact with real life. (16:17-20.) The opposite extreme of the pain-pleasure scale is apparent in the 
tendency shown by the adolescent girl to weep at the least occasion, or even with no occasion at all. Sometimes she seeks the solitude of her room or of some outdoor nook to indulge in the luxury of tears, especially if their flow is simply the result of nervous fatigue and tension. More often she uses them to obtain the love and sympathy of which she cannot have too much at this time, and finds them a potent means to gain the affection which she craves to a degree almost abnormal in its intensity.

Even more eloquent of her desire to prove attractive in the eyes of others is the passionate love of dress which possesses the girl in her teens. Watch the girls on their way to school. The "peg-top" skirts, full at the hips and narrow at the ankles, of some five years ago were replaced by the short full skirt, and more recently by long narrow lines. But whatever the fashion, the same adolescent tendency is exhibited,-happy the girl whose skirt is shorter or narrower than any of the daring styles worn by her mates. "Alice" blues and "Helen" pinks have yielded to "Victory" red, 
and no one can prophesy what shade the future may bring forth, yet we may rest assured that we shall see it in hair ribbons and sport coats the very instant that it is first rumored in the latest magazines. Instead of the flaunting pompadour we hear only of the "Castle clip" or "Mary Pickford curls"'; but the young girl has little thought for past styles in hair-dressing,-her one concern is to see that her newly put-up locks are arranged according to the latest vogue. And so it goes, until we wonder when they ever find time to look at the books they carry under their alms, and whether there is ever any thought in their minds beyond the fascinating subject of dress.

It is to be noted that another motive may lurk beneath this love of adornment than the naïve desire to arrest the roving attention of the male. With the dawn of adolescence comes a new self-consciousness as the awakening sexual and social instincts induce comparison with others and emphasize personal deficiencies hitherto disregarded. Psychologists have recognized that every piece of apparel serves to extend the personality, becoming, as 
it were, an integral part of the wearer's own ego. Hence the adolescent girl seeks to reinforce her self-respect and conceal her failings under the gaudy attire which she assumes. Thus she accomplishes a double purpose, winning the admiration of the other sex at the same time that she wards off social humiliations, which are agonizing to her new-born consciousness of self.

So deep is the adolescent longing for attention and sympathy, and so keen the sorrow over personal failings and criticism, that the girl is prone to indulge in long fantasies wherein she pictures herself lying cold and still in death while a throng of friends and relatives laud her to the skies as they mourn her untimely demise. Oversensitive to the least rebuke, which she interprets as a symbol of lost affection, she also thinks of death as a fitting revenge upon parents or others in authurity who have denied her wishes, or treated her harshly. If any proof were needed to demonstrate the fact that at this time of life the death wish is most foreign to the whole organic makeup, which is never more flushed with the joy of living, the 
very attitude of the girl in these reveries would furnish it. Never does she conceive of death as the absolute end of all things. Instead she always pictures her feelings as she stands apart and sees the mourners gathered around her body and hears their regret and praise. She only dreams of what would happen if she were dead. (16:p. 10.)

When the adolescent girl really does commit suicide, and occasionally she does do it in more than a day-dreaming way, it is because she has developed a pathological state of mind which only the psychoanalyst can understand. At the period of adolescence, the necessity of transferring the libido from infantile fixations to goals which have a wider social relationship becomes insistent. With normal individuals, this transference is made with little apparent struggle, but with neurotics, there may be a flight from the too stern realities of adult existence, and a seeking for refuge in insane delusions and neurotic obsessions, or even in an attempt to seek a pleasant oblivion like that of the pre-natal state in death. Thus, the very will to live, unable to make proper adjustments, 
and with its energy turned in upon itself, torments the soul in its futile attempts to find expression until it succeeds in the utter negation of its own purposive impulse.

After the first general reaction toward any member of the male sex, there follows a period in the career of the adolescent girl when she begins to exercise her powers of liscrimination to a slight extent, and to evince a preference for some particular individual among her acquaintances. Ordinarily, this choice depends upon certain physical traits which become veritable erotic fetishes upon which the young girl lavishes her devotion, while the personality below them is a minor detail. G. Stanley Hall (16), Slaughter (28), Smith (29), and others, have noticed this fetishistic tendency, and commented upon its common occurrence and dominating influence in the girl's life. It is noteworthy that the various characteristics which are thus idolized are all more or less intimately connected with sex from a genetic viewpoint,for Scharlieb and Sibley have remarked (26), as have other writers, that the hair, eyes, complexion, etc., grow brighter or clearer at puber- 
ty, while Holmes (18) has emphasized the fact that the voice, laugh, etc., had their origin in the mate calls of our animal forefathers. It is safe to conclude that concealment of the pri- mary organs of reproduction has resulted in the focussing of the attention upon the secondary sexual characters, so that these have become as stimulating to the senses as were the genitalia proper when our ancestors first assumed the upright position that brought them into prominence.

Quite as pronounced as the fixation on erotic fetishes is the ideal love $f_{0}$ an older person which is almost invariably a part of every girl's development. This, too, has been remarked by a large number of authors,-Kobl (20) and Slaughter (28) having given it especial attention. The psychoanalysts regard it as a normal stage in the transition of the libido from its fixation on the parent to its final goal outside the family group. To what lengths this infatuation for an elder person can carry an impulsive girl, is beautifully illustrated in the autobiography of a prominent woman writer of the 
day, published anonymously under the title "Me: A Book of Remembrance." (32.)

After several interesting adventures, the heroine, an 18 year old Canadian girl, "picks up" a travelling acquaintance who occupies her thoughts thenceforth. By the time he has rendered her timely assistance in her endeavor to gain a livelihood, she is desperately in love with him, and begs him to say that her affection is returned. She bends all her energies to living up to what she believes to be his idea of her.

"I deliberately blinded myself to every flaw in Roger," she states. "His selfishness and tyranny I passed over. It was enough for me that he descended into my life for a few days each month and permitted himself to be worshipped like a God. . . . Lolly called my love for him an infatuation. . . . She said that I was a hero-worshipper, and made impossible ideals of unworthy clay and endowed them with fictitious traits and virtues. She said girls like me never really loved a man at all. We loved an image we ourselves created."

Whether it is a real love or no, under its impulsion Nora is spurred on to do more than one act which she regrets bitterly afterward. Because Roger seems loath to declare his affection, she feels that her sentiments are not returned, and in wounded pride, takes pleasure in becoming engaged to other men,--no less than three simultaneously,-in order that she may prove the attractiveness which he thus treats so slightingly. Only when she makes the heart-breaking discovery that her 
idol is not only a married man but one of notoriously bad morals as well, does she attempt to control her madness, and instead of accompanying Roger on a trip to his hunting lodge, begins her life anew in devotion to her chosen profession.

Perhaps the best summary of this love of the young girl for a man much older than herself, although it neglects the psychoanalytic interpretation, is to be found in these words of Slaughter's :

"There is in the love of the older person a larger element of respect and the mystery of complete development, joined as a rule with sympathetic and gracious treatment. The situation is often one that gives opportunity for beneficial influence and guidance; the older person must not be flattered too much by adolescent affection; it is a passing phase and involves the projection of an ideal to which the older person may, in reality, only remotely approximate. Now and then, an adult will be found so deficient in either intellect or character as to treat the matter seriously or selfishly. Mating of this sort almost always faces disaster." (28:p.38.) 
The indefinite feeling of attraction which the adolescent girl at first feels toward the opposite sex, is often replaced, a little later, by a state in which a very conscious element of physical sexual desire predominates. That there is vast individual variation in regard to this, is obvious to anyone who has observed the adolescent girl even in a cursory and idly speculative fashion. The reason for this wide variation, as Blair Bell (1) has shown, is to be found in the metabolism of the ductless glands. 'This endocritic theory, while undoubtedly correct, does not explain the absence of a similarly broad degree of difference in the case of individuals of the male sex. In order to understand this phenomenon more clearly, we must seek the aid of genetic psychology, and it is just there that we find further facts which furnish us with an adequate explanation.

In the beginning of human life as such, man, like all other animals, had a definite mating season, of which traces remain even to this day. In proof of this statement, Havelock Ellis quotes examples of the outbreaks of venery that occur among the primitive tribes of Africa 
and Australia in the spring and fall, and among the Eskimos at the end of the long winter during which they are devoid of sexual desire.

Other evidences are found in the May Day and Harvest festivals of the rural British population and in the holiday celebrations of the European peasantry at these times of the year, which tend to assume orgiastic characters. The Chinese holiday called "Walking on the Green" is the survival of the old spring-time mating ceremony. A less obvious trace of the old periodic function of sex is the favoritism accorded to June weddings, which have become traditional, and the universally prevalent outbreak of "spring fever," which owes its origin to the restlessness created by sex tension.

As Corin points out (6), when the struggle for existence became less acute with man's increasing mastery of his environment, the necessity for a definite breeding season passed away, and the human species lost the pairing season which natural selection has generally preserved throughout the animal kingdom. The bi-pedal position, the loss of hairy covering, the intimate throwing aside of garments and the hud- 
dling together in the cave-dwellings, and the use of the hand for purposes of stimulating desire, all tended to focus the attention on the organs of reproduction, and to emphasize sexuality as it had never before been emphasized. (17.) The vast fund of energy which man had developed in his long battle with the environment and with other men, now turned to the sex function as an easily accessible and pleasant outlet, and he demanded that his mate give up all vestige of her old periodicity of function, in order that he might satisfy his new passion.

It was at this time that woman lost her place as the free and equal comrade of man. Previously, her share in social progress had been as great as his, for as Mason has shown (24), while he had been developing militarism, she had been initiating and perfecting industrialism. Now, however, man came to see in woman, in place of the co-worker, an object wherewith to gratify his lust. There was produced, by the slow process of natural selection, a race of wives too weak to resist such treatment, together with a second type who came to possess the ability to feel the sexual impulse at all times, with only 
traces of the old periodicity. Thus there came into being the erotic and maternal types distinguished by Ellis (8), Forel (10), and others, with all degrees between these two extremes. It is an undisputed fact that these types exist to-day, and it is herein that we have an explanation for the varying degrees of sensuality which are characteristic of the adolescent girl as of the adult woman.

The adolescent girl who is most deficient in the sexual side of her life may complete her existence without feeling any noticeable sexual desire; indeed, physicians report that they find a large number of cases in which female patients are utterly unable to experience any such feeling, and hence find their marriage vows extremely irksome. On the other hand, there are an equal number of exceedingly passionate women, who felt the physical sensations of sexual longing more or less spontaneously at some time during their adolescence.

This sensual craving is not manifested in the same manner in all cases, but may appear in any one of several forms. It is usually very much intensified just preceding menstruation, 
and again after the third day or so from the beginning of that function, becoming relatively quiescent midway between two menstrual periods. (31.) Some girls say that it becomes so strong at this time as to prove a temptation to masturbation or to illicit intercourse. Often this feeling is first aroused by an accidental touch, for touch is intimately connected with the reproductive function. (14.) One girl states that she experienced her first sensual thrill when her bosom touched that of her partner during the dance; another that her first sensation of this kind was received as she clung to her escort in an agony of terror; and many are thus awakened by the kisses and caresses of their lovers. Most often, the waking consciousness succeeds in inhibiting a sensation that it has been taught to regard as sinful, and it is carried over into the dream life, where such vigilant censorship is impossible, due to the relaxation of the higher nerve centers in sleep.

Until the psychoanalytic practice came into being, the dream-life of the adolescent girl, like that of everyone else, was in large measure a sealed book, but with the aid of careful analyses 
made by Freud, Jung and their followers, we can at least formulate some general statements which will hold true in the majority of instances. To Dr. Sigmund Freud belongs the credit for giving us a key for the interpretation of dreams, a contribution as significant for the proper understanding of the psychic life of the adolescent girl as it has been in the treatment of neurotic cases, in which connection it was evolved. Stated in the briefest possible terms, the Freudian theory holds that the dream is the fanciful fulfilment of a suppressed wish, which the waking consciousness will not admit into its ken, but which escapes from this inhibitive influence or censorship, during sleep, and runs riot in the dream life.

It is hardly surprising that the unconscious sexual desires form a large part of this suppressed impulsive energy, for their normal satisfaction is very often incompatible with established social standards, and the dictates of conscious morality even go so far as to forbid the slightest thought of their existence. So deeply, indeed, is the necessity of denying such wishes impressed upon the whole psyche, that very 
often the sexual meaning of the dream itself has to be cumningly hidden in order to escape the vigilance of the censor, so that there must be distinguished in the dream content a whole series of symbolisms which have received an erotic meaning through the old phallic ceremonials of ancient religions, although their sexual meaning has long since been obliterated from the conscious memory of the race, and persists only in the submerged levels of the unconscious psyche. $(5: 11$.)

This suppression of any crudely sexual desire, even in dreams, is especially typical of women, because they have been taught for centuries that passion was the unique possession of the male organism, while the female merely submitted to this sinful act in order to insure the birth of offspring. Thus it has happened that former students of sex psychology have noted the sexual dreams of the man who is practicing continence, but have been strangely silent as to the experiences of women along this line. The psychoanalysts, however, have broken through this barrier of delicate reserve, and have described symbolic dreams of purely 
sexual character which they have brought to light in their treatments of nervous diseases. An especially good example of such a dream in the case of an adolescent girl who came to him for treatment is described by Dr. Frink in his latest book. (13: 452.).

Miss Sunderland, the patient in question, dreamed "that she was struggling with a large, long-nosed, gray dog which was trying to bite her, while she endeavored to prevent it by holding its mouth shut with her hands. The dog finally did bite her somewhere in the thigh. She saw a little blood flow from the wound, and then she awakened, terrified. This is evidently a sexual dream. Its symbolism is very typical. Young girls are apt to conceive of sexuality as something animal-like or violent. When, therefore, a girl dreams of some violent attack or assault, one can feel assured that she has in mind something sexual. And when this attack results in the shedding of blood and is followed by swelling of the body, the analogy to defloration and a resulting pregnancy is so striking that there need be little doubt as to what the dream means." In this case, further analysis showed that the dog of the dream represented a young man with whom Miss Sunderland was really in love, though hesitating to admit it, and whom she finally married.

An elaborate set of the sexual symbolisms which most frequently occur in these erotic 
dreams has been worked out by the psychoanalysts, and is probably more or less universally applicable, although it is far from being the all-inclusive content of the dream psyche which was at first claimed for it, as further analytic work with cases of war shock has shown. Herbert Silberer, too, has emphasized the multiple factors of dream interpretation, and concludes that its symbolisms not only veil a suppressed wish of lowly somatic origin, but also express the idealistic strivings of mankind to sublimate this unconscious energy into forms which shall be higher and more beneficial to the individual and to society, just as the alchemists of old tried to transmute the baser metals into pure gold. (27.) That this process is often very beautifully carried out will be demonstrated in a succeeding chapter.

It has been the habit of psychologists to deal with the sexual dream of the girl as entirely symbolical, if at all occurrent, for the assumption is made that she never experiences the definitely sexual dreams of her brother. Exchange of confidences with other girls has justified the conclusion that this is an entirely erroneous im- 
pression, for the adolescent girl very often dreams of ardent love-making with some man of her acquaintance. or even with someone who is an entire stranger to her waking thoughts. Often these dreams end with the fantasy of sexual intercourse, and even result in a complete sexual orgasm. Day-dreams, too, may take on a specifically erotic character, particularly in the case of girls who have been involved in more or less ardent love affairs, and who are temporarily forced to forego the accustomed caresses of the lover.

There is one other aspect of the sexual instinct in the adolescent girl which has received all too little attention except as it has been seen in manifestations so extreme as to be pathological in nature. Intimately connected with the emotion of sex, as the psychoanalysts have. noted in their studies of neurotics, is the sentiment of fear. In woman, the fear element is especially predominant, not only because the results of sexual intercourse are more involved in her case, but because for the inexperienced, at least, a vast body of tradition emphasizes this element,-the fear of defloration pains, the 
horror of passion which she has often been taught is unwomanly, and in cases of extreme ignorance, dread of the unknown processes of the sexual act itself.

In the face of so many terrors it is to be wondered that almost every girl dreams of marriage, and more especially is it astonishing that so many defy conventional morality to become mothers outside the sanction of wedlock. In order to understand this apparent courage, we must recollect the masochistic tendency which is to some extent a part of the female sexual nature. Throughout a long biological history, man has been the aggressor to whose advances woman has passively yielded her charms; he has been the wooer, she the wooed. And this long accustomed compliance with the desires of the more ardent male, necessary for the continuation of the race, has become the natural heritage of woman, so that the impulse to yield to her mate, lawful or otherwise, is stronger than all the fears of present or future pains which may result. Thus it is that we see in our present social system the wife who is faithful to a brutal husband and the girl who is a 
social outcast, both equally anomalous until we recognize that the masochistic sacrifice of self is a fundamental concomitant of the sexual life of womankind.

These generalizations concerning the sexual instinct of the adolescent girl are more forcibly illustrated by some of the concrete examples which led to their formulation. Except for the description of Mary MacLane, which is drawn from her books, the exact words of the girls are quoted. Nearly all the girls who have been under close observation are the college and university type, and this makes their cases the more significant when it is remembered that many of them have been brought up under the strictest possible code of repression, so that for a long time their sex life was wholly a matter of instinctive response, unguided by any definite information. It is my impression, gathered during two summers' work with factory girls (not in social welfare, but as coworker with them, so that the observations were perfectly free and natural), that with girls of this class the awakening of physical sexual de- 
sire is earlier and more intense. This is due partly to their different environment in which the sexual side of life receives more emphasis, and partly to the fact that they lack adequate means for sublimating their biological energy into intellectual and artistic effort.

Mary MacLane $(21 ; 22 ; 23)$ carries her sensualism over into every other sensory domain, so that the red line of the sky at sunset becomes a symbol of the passion which shakes her body, the feel of her garments and even the prosaic eating of food becomes tinged with erotic pleasure. But far from being contented with these symbolic and substitute erethisms, she longs most intensely for the hour which shall give her the supreme satisfaction of physical love in its intensest form, and all her day-dreams center upon this supreme height of her ambitions. Her dream-partner is visualized as a gray-eyed, gentlemanly devil, who may ruin her soul if he will, so long as he gives her the supreme satisfaction which her being craves. Thus all her desires converge to the moment in which she can experience in her own person that acme of pleasure, sexual love. One does not wonder that when she writes her third book, Mary confesses that she has never found her dreams realized, for such elaborate visions, whatever their theme, could scarcely hope to find their counterpart in the world of reality. It is noteworthy that in this last volume, too, she has replaced her first dreams of a lover with quite as pas- 
sionate a fantasy of little dream-children whom she holds in her arms, and warms against her breast.

\section{Reports of Adolescent Girls *}

Case 1. My ideal of life after college is marriage, with opportunity to continue work in designing. My plans and interests have broadened with my increase in knowledge. For instance, before entering high school my highest ambition was to be a public speaker and wear a black spangled gown, for I had once seen a reader so dressed and greatly admired her.

Quality of work is lowered during the first part of menstruation, increased during the last part. Marked mental depression during first two days of menstruation, followed by an opposite mental attitude. Languid for first two or three days, then emotions greatly increased in intensity, desire to dance, etc. Yes, I know that a girl who has had no actual sexual experience can have dreams of that nature. In myself, they occur after a dance, or any occasion where there has been unusual sexual stimulus. I have spring fever, too, which is similar to the emotion before and after menstruation. It seems to be due to an accumulation

* These reports were obtained from friends, and girls who wrote me at the request of mutual friends, in answer to very plain questionnaires. I have given the selected answers verbatim, at the risk of reproducing irrelevant material, because they afford such remarkable insight into the mind of the adolescent girl. The questions concerned day-dreams, erotic dreams, experience at menstruation, ideals for the future, religious beliefs, etc. The last question (on religious beliefs) has no bearing on the subject of this chapter, therefore the answers to it are omitted from the reports. 
of superfluous energy, and I usually indulge in some strenuous exercise.

Case II. When I entered high sehool, I had no plans further than going to eollege so as to have some good times, living in a dormitory. Then, towards the end of my eourse, I realized that after college one earned one's own living. I thought it would be delightful to be a librarian, for one who loved books must be happy if always with them. But after applying for entrance at Simmons, I solemnly decided that I'd better not beeome a librarian, sinee all I knew of that speeies were withered old maids. I then thought it would be so satisfying to have taught sehool, and be able to say of great men, "I used to teach him." After a few years of teaching I wanted something tangible as a result of my work, so I decided to become a trained nurse. Only one friend approved this idea. Finally in selfish desperation, I planned on a delightful time studying German at college. Then I was surprised to find my dreams realized in the seience of Sociology.

For a while the fascination of Psychology lured me away from Sociology, but I gave that up as I had given up nursing. Jones' book on Psychoanalysis made the work of an alienist the most attractive that could be done, just as Aice Freeman's life and Jane Addams' Twenty Years at Hull House made an unselfish life seem attractive.

I am always depressed at the menstrual period. Consider myself a failure, unworthy of success. The third day I have always been very lonely, and strongly attracted by the idea of masturbation. Still, I alway's 
feel with unusual strength the sanctity of sex at this time, so that I never experience any rebellion against the occurrence of menstruation.

When I was seven, my father told me that the baby sister came out of mother, not out of the doctor's bag. . . . Two years ago, Dr. X__ said something about a woman who was trying to appear young. He knew that she was older than she said, because he had known her for years. Besides, she had had a Cesarean operation when her child was born. Did I know what that was? No? Well, right then I learned. that babies were not commonly born through the navel. From Havelock Ellis I learned all else there was to know about sex. It was marvellously interesting. For the first time in my life, I became curious, but Ellis went into so much detail that my curiosity was satisfied before it was aroused, almost. I earnestly hoped I was normal sexually, and despised women who were not. Marriage seemed a much more definite thing, and more interesting, really a career in itself. Men now seemed different from women. They all appealed to me rather strongly for a time, but gradually I was forced to find sublimation, as I found that I did not appeal to them any more than I ever had. My fondness for children ran a parallel course with my desire for masculinity.

In my nineteenth year, I remember being much shocked at my moral depravity because of two dreams. In the first, I was sitting on a beam in the barn with a grammar school boy pal, when I felt very much elated in a peculiar manner because my bare foot 
touched his, and we swung our feet together a moment without speaking. Not many nights later, I dreamed I went down through a hole in the ground, as did Alice in Wonderland, till I came to a beautiful garden. Here, a radiant man, naked, embraced me with his hands and feet so that we seemed welded together. After reading Havelock Ellis I dreamed several times of having sexual intercourse.

I used to think it was simply pre-ordained that somewhere in this big world there was a man whom I should meet in the far future, who would be the perfect complement of myself. We would love each other when we met, and until death. I never would do any cooking, so he must be willing to eat raw food. My career would not be interrupted. We would have fifteen children, who would take care of each other. Now, I have been seriously looking at every man I meet, but I do not find him. I realize that I may never find him. But it does not mean so much to me as I used to suppose that it would. It means simply a choice between a narrow and a wide circle of interest. For children do not take care of each other. And I don't think I'd like to eat raw food myself. My daydreams are of success, and of self-sacrifice. I have never dreamed of lovers or of love in them.

Case III. During menstruation I am weaker physically and overcome with weariness for a day, sometimes, but I do not notice any tendency to be irrational, excitable or morbid. I am simply depressed somewhat by physical languor and sometimes pain. I have attacks of spring fever, but have not noticed 
any similar differenee near the menstrual period. I should say my spring fever was attacks of the blues, due to nervous fatigue, discouragement in my work, and desire for masculine company, to put it mildly. I find relief in physical exercise, or work, or writing, usually to someone.

At the age of ten, my mother explained most of the physiological phenomena concerned with reproduetion, and showed me the big colored illustrations in my grandfather's medical books. I was assured in beautiful language that it was all very lovely, but it took me some years to have any respect for sexual intercourse or see anything but pain and horror in childbirth. At present, though I love children, I do not like the idea of being tied down. If I could combine my ambitions with married life and motherhood without hurting eitlier, I should be most happy. I cannot tell which call will prove the strongest, but at present it seems that art is.

I can not recall definitely any erotic dream, though I often have them. They are usually vague, unconventional, but not naughty. Complete sexual experience is not necessary for crotic dreaming. My sexual experience has been all but complete, and I have dreamed only a small part of it, such as kissing, physical contact and pressure, but other girls of my acquaintance have dreamed all this and more.

When I was about thirteen, my day-dreams were romantic adventures with handsome men. With the more picturesque events, such as narrow escapes from being murdered by brigands, etc., I imagined all the 
ramifications of sexual experience. This last I do today, but with added details taken from real life. Books do not tell us so much of the actual workings of such things. Nowadays, my day-dreams are less romantie, and get down to business. I imagine myself being eharmingly earessed and supported (bodily, of course). I am delightfully passive and dependent in some strong man's arms, but I also imagine living a humdrum existenee with him. A very common dream is partly memory amplified. I go over in my mind two or three love affairs, adding and guessing what might have happened, and ending up with a feeling of relief that I was not carried off my feet and tied up with a wretched, unsuited existence.

Case IV. My plans for the future have ehanged a great deal sinee I entered high school. Then, my ambition was to become an actress. I had no grcat appreciation of dramatic art, but the excitement and glamour of the stage appealed to me strongly. In my Junior year of high, a very wonderful English teacher made me feel that a life of service was more important than anything else. I adopted the idea of being "an angel of the slums," and felt that in order to gain my life I must first lose it. This ideal remained with me in a somewhat modified form until my junior year in college, when the fascination of Zoology decided me to become a doctor. I do not know how I shall find the life of service, even yet.

I have never noticed any marked difference in the quality of my work at menstruation. It does not seem to affect my mental or physical condition in the 
least, as it does those of most girls, but I am a little weakened physically. After the first half day, I can see little change from my normal condition.

No one has ever given me definite information concerning sexual matters, and it was a long time after the first menstruation that I received any information at all,--probably I was about sixteen. Nearly all I know has been gathered from scattered reading, hearsay, and certain Zoology courses. At times my lack of knowledge has given me some grave fears, and made me nervous in having anything to do with men. I have never, since I was a tiny child, cared as much for men as for women, but I have never felt any repugnance to them. If $I$ ever met a man who came up to my ideal, and who loved me as I should want to be loved, I should marry him without hesitation. I never felt particularly favorable to the idea of having children. I must confess that it is repugnant to me in every way,-and then, children are such an uncertain lot. However, if I loved enough to marry, which is doubtful, no sacrifice would be too great.

I can recall no erotic dreams, and have heard very little about them from other girls.

Case. $V$. I read a great deal from seven years or so up to the time I went to college. Reading has given me most of my cultural interests and many of my ideals. In college, I liked English and History for the subjects themselves, and Sociology and Polities because of the teachers.

I am not sure as to the effect of menstruation on 
the quality of work done. The quantity is less, and there is more effort, I have no pain, but am languid and lazy, cry easily. I find no marked effect on the sexual emotions. Am apt to be discouraged or irritable the day before the beginning of the menstrual period.

After an experience with a playmate in mutual masturbation at nine or ten, I repented, and turned to better ways. I had two bitterly repented lapses at twelve and fourteen. At eighteen, I was more often tempted, but my lapses were few and far between, and from twenty-one to twenty-four I had a record free from masturbation. During this period of repression, the denied desire expressed itself in very vivid dreams. I would wake thinking the dream had been real, then realize it to be a dream with mingled feelings of shame and relief.

My day-dreams center around a home clearly visualized. I picture myself as the mother of a large family, but their father is a shadowy being. My dreams about special men are always concerned with going somewhere, dancing, etc.

Case VI. My dreams of the future have always been more or less influenced by favorite teachers, I believe. In high school, encouraged by a beloved teacher, I determined to go to college and prepare myself for a life of teaching Mathematics, but once there Chemistry and Physics lured me, as I liked the teachers of those subjects. Of course, the subjects themselves opened up new and hitherto unexplored fields to my exploring mind, but without inspiring 
teachers, my interest would have waned, as it did in Irathematics.

At the menstrual period I have marked attacks of inental depression. There is little or no physical pain, though I am more apt to have some pain than formerly, probably on account of increased sexual tension, and nervous strain. Work requires an effort of the will, and causes extreme fatigue. I experience marked increase of sexual desire just before the beginning of the menstrual period, and again after the third day of that function. I also have very vivid erotic dreams at this time. These dreams began when I was twenty-one, and have recurred frequently ever since. Sometimes I awaken before the act is completed, but more often, an entire sexual orgasm occurs. The dreams are most apt to occur well toward morning, and on sereral successive nights, after which I am too weary to care for anything in the sexual line for a time.

Spring fever is a prolongation of the depression and restlessness and desire for love which accompany the menstrual function. I satisfy it by outdoor life or intensive flirtation.

My day-dreams were originally concerned entirely with my ambitions for a career and a life of social service. I had never known of physical sexual passion until my Junior year at college, when I heard a lecture on sex hygiene. At about the same time, in the course of dances, I began to feel distinct bodily thrills from the pressure against my breast as I was held closely in a partner's arms. Even yet I could 
not realize that men definitely attracted me. Then I learned about birth control, and realized that marriage must involve frequent sexual relations. As the conscious sexual desire increased, and I began to want the experience I was having in dreams in actual life, I day-dreamed of having maseuline love. This reinforced my plysical longings, and made me sure I wanted marriage, if it did not necessitate my renouncing all other work.

Case VII. I was put in the convent when a child and came out at 17 . During summer vacations I made friends with other girls, and always hated to go back to the convent school and leave them, for I loved them. When I was 16 , one of the girls gave me a novel; I stayed up all night to read it. $\mathrm{Oh}$, how I wanted to be loved! I wondered if I would ever meet a man to love me like the hero in that book. The same week I went back to school, and according to rules had to go to confession. The novel reading was my biggest $\sin$. I was so afraid the priest would scold me. Instead he smiled. Yet he said, "My child, there are bad books, and you who are pure at heart must never know them. The world is full of bad men, too, you should stay here in the convent, and devote your life to prayers and saerifice." All that year he kept trying to persuade me to stay in the convent, but I wanted to see the outside world. I wanted love, though I knew so little what it meant.

The summer I was 17 I left the eonvent for good, and began to work in my father's store. One day,- 
the very day I put my hair up for the first time,a salesman asked me to go for a spin in his big car. I felt I was really grown up at last. I told him I was 19 , it sounded older than 17 . I said, "Wait a minute till I tell Father." He didn't seem to like that. Well, dad didn't like it either. He sent me home, and the salesman never came back to the store again. My sister told me not to be too nice to strange men. I wanted to know why, so I answered an advertisement and got a book called "Sexual Science." It was a medical work, and I read it whenever I had a chance. My sister found it and took it away from me. Then I got library books on anatomy, etc.

At 18 I began my nurse's training. At $19 \mathrm{I}$ got my first private case, a man patient, but I was too busy to think of his sex. At 21 I saw the first circumcision case in the operating room. It was the first time I had realized consciously the anatomical difference between the sexes. The doctors teased me because I blushed so much.

It was after this that I began to have such vivid sexual feelings. A few days before and after menstruation, how I longed to be loved. I flirted with the doctors at those times, but at the last minute I'd back out,-I was scared,-and my religion came in, too. They would be provoked, but always let me go, because I was still so innocent.

I am now 23, and deeply in love with another Catholic, who has always respected me as the doctors never did. I have often dreamed of having sexual intercourse with him after he has been caressing me. 
I know now that I am the passionate type, and I used to think I was very bad to be so, and bound straight for Hell. Lately I have come to understand that it is natural for women to have sexual feelings and my mind is more at ease, but for a long time I thought I was really going to be bad as the nuns said.

Even these few concrete cases show as no amount of abstract discussion could hope to do the strength and vividness of the new affective life upon which the girl enters at pubescence. But the all-important point is the tendency of the sexual impulse to pass over into other forms of emotion, so that the girl is actuated more powerfully by fear, anger, or more especially the religious and asthetic emotions than at any other time during her life. Frink notes this tendency of the sexual energy to reinforce other emotions in his studies of pathological cases (13: p. 259), and points out that no physiological difficulty is involved in this transformation since the same metabolic changes are common to all other emotions as to sex tension. It is this transformation of the emotional energy which suffuses the young girl with a sense of shyness closely akin to fear, or gives her 
the repellant boldness which makes her appear to be devoid of all sentiments of modesty and humility. Often this unstable emotional state fluctuates between the extremes of joy and sorrow, so that the transition from the supreme ecstasy of happiness to the lowest depths of despondency may be the instantaneous result of the most trivial occurrence. With this affective transmutation is correlated congruous efferent outlets, so that the sexual impulse, denied its primary expression, seeks other pathways, sometimes abnormal and injurions, but more often of great use and beanty for the individual and society. A detailed analysis of these vicarious sexual activities will be presented in later chapters.

Although the thought of motherhood is not rigorously repressed from consciousness like the idea of sexuality, it is not so easy to detect the presence of any deep maternal instinct in the makeup of the adolescent girl. Anticipations of motherhood are indeed inculcated in almost every girl as a matter of social tradition, but for this very reason it is difficult to be sure just how much of the enthusiasm and love 
for children which she professes is spontaneous, and how much is due to the unconscious motive of desire for social approval. Dreams of childbirth, which are perhaps more common among girls than the purely erotic dream, are certainly unmistakable evidence of the existence of such an instinct during adolescence, and the psychoanalysts admit that the basis of many a symbolic dream is the secret desire for children rather than suppressed sexual wishes.

In visions of a home and children, again, the day-dreams of the adolescent girl find a fertile theme; indeed her fancies are quite as much occupied with painting pictures along this line as with the visualization of the man who is to share this happy future. As Dr. Peters* has found in her work with adolescent girls, the ideal man is more often the ideal father than the perfect lover, and the Eugenic motive is taking an ever increasing part in the young girl's conception of her "Prince Charming." That the modern girl is beginning to choose for her husband the man whom she wants to see as the father of her children at least augurs

${ }^{*}$ See preface. 
well for the future of the race, and it would also seem to indicate the first faint stirrings of the maternal impulse.

Kohl suggests that the maternal motive prompts the mothering of younger brothers and sisters, and also appears in the love of strange little children and baby animals. All these traits are very apparent in the adolescent girl (19). The adolescent passion for secrets is recognized by G. Stanley Hall as genetically akin to nest-building and home-making, which were activities carried on with the utmost caution during the long phylogenetic history of the race. That there should be even these suggestions of a maternal instinct during adolescence is remarkable when we consider that at best it can only be faintly prophetic of the powerful impulse to come, since it lacks the complete physiological background which only motherhood itself can give.

\section{BIBLIOGRAPHY FOR CHAPTER II.}

1. Bell, W. Blair. The Sex Complex. 233 pp. Bailliere, Tindall \& Cox. London, 1916.

2. Burnham, W. H. A Study of Adolescence. Ped. Sem. June, 1891. Pp. 174-195. 
3. Biérent, Leon. La Puberté chez L'homme et chez La Femme. 200 pp. Société des Editions Scientifiques. Paris, 1896.

4. Cannon, W. B. Bodily Changes in Pain, Hunger, Fear and Rage. 311 pp. Appleton. N. Y., 1915.

5. Coriat, I. H. The Meaning of Dreams. $194 \mathrm{pp}$. Lit. tle, Brown. Boston, 1915.

6. Corin, James. Mating, Marriage and the Status of Woman. 177 pp. Scott. London, 1910.

7. Crile, Geo. The Origin and Nature of the Emotions. 240 pp. Saunders. Philadelphia, 1915.

8. Ellis, Havelock. Sex in Relation to Society. $656 \mathrm{pp}$. Davis. Philadelphia, 1910.

9. Studies in the Psychology of Sex. Vol. II. 2 vols. Davis. Philadelphia, 1900.

10. Forel, Auguste. The Sexual Question. 536 pp. Rebman. N. Y., 1908.

11. Freud, Sigmund. The Interpretation of Dreams. 499 pp. Maemillan. N. Y., 1913.

12. - Three Contributions to the Sexual Theory. 91 pp. Jour. Nerv. \& Ment. Disease Pub. Co. N. Y., 1910.

13. Frink, H. W. Morbid Fears and Compulsions. 568 pp. Moffat, Yard. N. Y., 1918.

14. Gallichan, W. M. The Psyehology of Marriage. 194 pp. Laurie. London, 1918.

15. Hall, G. Stanley. Adolescence. Vol. I. 2 vols. Appleton. N. Y., 1904.

16. - Educational Problems. Vol. II. 2 vols. Appleton, N. Y., 1911.

17. What We Owe to the Tree-Life of Our Ape-Like Ancestors. Ped. Sem. V. 23, 1916. Pp. 94-119. 
18. Holmes, S. J. Studies in Animal Pehavior. 262 pp. Badger. Bostor, 1916.

19. Jung, Carl G. Collected Papers on Analytical Psychology. 492 pp. Moffat, Yard. N. Y., 1917.

20. Kohl. A. Pubertät und Sexualitat. $\$ 2$ pp. Kabitsch. Würzburg, 1911.

21. MacLane, Mary. The Story of Mary MacLane. 322 pp. Stone. Chicago, 1902.

22. - My Friend Annabel Lee. 262 pp. Stone. Chicago, 1903.

23. I, Mary MacLane. 317 pp. Stokes. N. Y., 1917.

24. Mason, Otis T. Woman's Share in Primitive Culture. 295 pp. Appleton. N. Y., 1899.

25. Marro. La Puberté chez l'homme et chez la Femme. 535 pp. - - Paris, 1901.

26. Sharlieb and Sibley. Youth and Sex. $92 \mathrm{pp.}$ Dodge. N. Y., 1913.

27. Silberer, Herbert. Problems of Mysticism and Its Symbolisus. 151 pp. Moffat, Yard. N. Y., 1917. 28. Slaughter, J. $\mathrm{W}^{r}$. The Adolescent. $100 \mathrm{pp.} \mathrm{Sonnen-}$ schein. London, 1911.

29. Smitl, T. L. Types of Adolescent Affection. Ped. Sem. V 11, 190\%. Pp. 178-203.

30. Starr, Louis. The Adolescent Period. 211 pp. Blakiston. Philadelphia, 1915.

31. Stopes, Marie. Married Love. 117 pp. Fifield. London, 1918.

32. Me: A Book of Remembrance. Century. Vols. 67-68, 191t-15. 


\section{CHAPTER III}

\section{THE ADOLESCENT CONFLICT}

Origin of individualistic impulses; Will to power; Factors which reinforce will to power in adolescent girls; Illustrative cases; Freudian interpretation of the conflict; Cases which illustrate the conflict between the will to power and the racial impulses; Feminism and the masculine protest; The real adolescent conflict.

With the influx of sexual impulses into her soul, the adolescent girl enters upon a period of intense mental conflict, for these new motives have been utterly foreign to all her previous experience, and not without a struggle to retain their old supremacy do the egocentric tendencies give way to the altruistic feelings and emotions. The self-regarding instincts have their genetic origin in the self-preservative activities of the lower organisms, the primordial expression being the absorption and assimilation of nutritive material. The whole complex struggle for existence, both passive and active, is 
rooted in this same desire to prolong individual existence, a desire which is as truly a form of the whole libido, or élan vital, as is the less selfish racial energy, which strives for the preservation of the species.

In the human species, the egocentric motives have also a broad psychic irradiation which has been aptly named by Adler, perhaps through the influence of the Nietzschean doctrines, the will to power. There are several factors which unite to reinforce this Wille zur Macht at adolescence, so that it becomes no mean competitor with the racial impulses in the struggle for dominance over the psychic life. Adler, himself, developed the theory of the power motif as an explanation of the neurotic constitution, in which he considers it the guiding principle (1). It exists just as truly in the normal individual, however, but the latter is better able to make his adaptations, so that his conflicts are not as disintegrating as those of the neuropathic psyche.

Physiologically, the will to power is conditioned by some defect in bodily structure or function, for which the nervous system at- 
tempts to compensate by exercising its regulative and coördinative powers to induce other organs and systems to take over part of the duties normally performed by the deficient member. On the psychic side, the organio weakness and consequent nervous strain of the effort of adjustment are accompanied by a general feeling of inferiority, for which the individual attempts to compensate by a striving for power, in the hope of thus convincing himself that his fear is groundless (2). In these days of lenient natural selection, it is to be expected that the vast majority of individuals would suffer from some physical imperfection, so that this feeling of inferiority, with its compensating power motive, is a common factor of the psychic life. That it is intensified in the adolescent girl can be readily demonstrated, in spite of the fact that at this stage the racial impulses become paramount.

With the onset of pubescence, and the beginning of menstruation, there is first brought into the focus of consciousness the radical difference between the male and female organisms, a fact which has hitherto been little considered 
by the girlish mind. Indeed, as both Ellis (5) and Adler (1) have remarked, the child is very often uncertain to which sex it belongs, and always likes to consider itself a boy, because the father is to it the embodiment of all that is strong. Adler further emphasizes the rebellion of the adolescent girl against the admission of her femininity, which results in the formation of what he terms the masculine protest, or setting up the ideal of manly power as a guiding principle, a process which may be either conscious or unconscious. This refusal to be reconciled to the feminine rôle is almost universal, for the physical pains of menstruation and the accompanying mental depression are bitterly resented, and at one time or another almost every girl has been heard to exclaim, in passionate protest, her desire to be a man.

It is now, too, for the first time, that the girl begins to feel the irksome restraint of conventions which she has been permitted to disregard during her childish days, and she is not at all pleased at being forced to submit to a control which she sees her brother calmly ignoring. And with her new freedom, and possibility of 
economic independence, the modern girl has a means of expressing her rebellion which was denied to generations which had before them only the possibility of marriage or a life under the parental roof. Thus her antagonism to the established order of things, either biological or social, is expressed respectively in the antipathy to motherhood or in the flaming resolve to sweep away double moral standards and create a mode of living as free as man's.

Various other factors unite with these, so that the desire to control and dominate may become the ruling passion of the girl's life. As Adler found in his clinical studies, this motive is very often prominent in the etiology of the neurosis, the neurotic affliction being used as a weapon to enforce attention and coddling from friends and relatives, so that the sufferer feels herself the all-important center of affairs. These interacting factors which determine the power complex can be seen best in connection with concrete examples, however, so we shall turn aside from our abstract discussion at this point, to a consideration of a few cases which 
furnish excellent illustrations of the thesis upheld by Adler and his followers.

Case I. Miss Grey was an attractive girl of twenty. The focal point of her complex was a negligible facial disfigurement in the shape of a peculiar birthmark. A deeper organic weakness of the alimentary tract was the fundamental cause of her feeling of inferiority and compensating will to power, and the birthmark was merely the conscious symbol of her complex. Her mother's unwise treatment fostered Miss Grey's feeling of inferiority, for she was always comparing the dress, manners, and personality of her daughter unfavorably with those of her older sister.

The psychic compensation for the feeling of inferiority was an inordinate craving for admiration and attention, which was gratified by fantasies when denied legitimate satisfaction. A strange malady was developed which brought her to the notice of leading specialists, unavailingly for its cure, but in a way to gratify the longing to be the center of attention. Girl friends were pictured as having desperate "crushes," or as consumed with jealousy of her superior attractions. Every man who offered any attention was conceived to be madly in love, and filled with despair because of the coquettish treatment to which he was subjected. Indeed, every act became a direct outcome of the lust for domination.

At length the power complex assumed an almost tragic aspect, causing a rupture with Miss Grey's most intimate friend because she had consoled a cast. 
off lover of Miss Grey's. Previously, the adoration of this girl friend had been very comforting, but as Miss Grey saw one iota of her power abate, she employed every artifice she could devise to wreak vengeance upon her erstwhile chum. Failing in this, she left college to enter a private school, and finally found a better way to satisfy her longing for power through her literary efforts, which received recognition in the new environment.

It is to be admitted at the outset that Miss Grey is extremely neurotic, yet in the final analysis her motivation is no different from that which actuates the normal, healthy adolescent. It is merely so intensified in her that it is readily distinguishable from the complex of interacting forces which shape the course of human destiny.

Case II. Marie Bashkirtscff, as appears in her famous journal (3), was born of an aristocratie family, but because her father and mother had separated in early childhood, the consciousness of her noble lineage was shadowed. This was undoubtedly one source of her feeling of inferiority. That a more definite physiological background was not lacking, we are assured by the knowledge that she died of consumption at the close of her adolescence, which suggests that she must have been endowed with the delicate physique which strives for psychic compensation through the will to power.

All her day-dreams express this longing, from those early visions in which she pictured her beloved duke brought to her feet in admiration of her talents and 
intellectual ability, to the later reveries in which she sees herself the artist of the hour, a figure of worldwide fame. The feeling of inferiority tortures her when she believes herself spurned by the cardinal's nephew, and she persuades herself that she never really lored him at all, but was simply whiling away the time in idle flirtation. Doubtless this statement is perfeetly correet, sinee she is never satisfied unless every man she meets falls vietim to her ebarms, thus satisfying her longing for power. Over and over again, as the feeling of inferiority seizes her she shakes off her depression by the vehement assertion that she is beautiful, talented, intelligent, above all other women. She seeks to reconeile her father to her mother in order that she may have the delicious sense of being able to rule the gruff temperament that has always refused feminine influenee. She beeomes an ardent student that she may impress people with her superior mental ability; she paints like a madman or a genius, in order that she may truly become the latter; finally, she writes her journal, in order that her wonderful personality may at least impress the world, for her worst fear is that she may die without having gained the fame she craves so intensely. And then her short, high pressure life burns out, and the pitiful attempts to assure herself that her weaknesses are wholly imaginary are forever ended.

Case III. C. S. Yoakum and Mary C. Hill have given an interesting report of the imaginary aetivities of Miss $Z$, which furnish a rich field for a psychoanalyric study of the power motive $(9)$. 
Miss Z's complexes were uncarthed during the course of memory tests in the psychological labora. tory where she was a student. Her remarkable memory for the "Binet Letter Squares" was found to be due to the association of each letter with some word, the group of words with these initial letters forming a series of pictures from Miss Z's past experiences or connected with her "complexes." Thus each square came to represent some powerful affective element in her life.

Detailed study of Miss Z showed that ever since childhood she had been in the habit of indulging in mental imagery not at all connected with the work in hand, yet she has so adapted herself to this daydreaming flight from reality, that it has not interfered with her becoming one of the most brilliant students at the university. Nevertheless, this train of reveries, which is fairly continuous, conditions her reactions much more than stimulation from her outer environment, a characteristic suggestive of the introvertive type of mind.

Without going into any elaborate résumé of the study and conclusions presented by Yoakum and Miss Hill, we may select those points in Miss Z's history which immediately stand out as significant for the psychoanalyst. She desires above all things to shine in literature, but dislikes sciences,--another evidence of the introvertive tendency to flee from reality. This shrinking from the harsher things of existence becomes explicable when we learn that Miss Z during her whole college course was in danger of a collapse on account 
of her anæmic condition, and we understand that she is possessed of the typical "neurotic constitution" in the Adlerian sense of the term.

This neurotic weakness was manifested in the two typical forms: the feeling of inability to cope with the problems of a normal life, and the compensating will-to-power, expressed in the desire for inteilectual superiority. These two motives have an obvious expression in certain mental attitudes and reactions characteristic of Miss $Z$ at the present time.

In the first place, Miss $Z$ admits of a very definite wish that she might remain a child and be always with her mother, and confesses that she is constantly tortured by some unnecessary fear. These are typical reactions of the neurotic feeling of inferiority, and together with her consciousness of her own de. feets and the resultant shyness have kept her from enjoying the comradeship which every adolescent craves.

In order to console herself for these failings, Miss $\mathrm{Z}$ has created for herself in her reveries a beautiful and gracious dream princess, with whom she more or less identifies herself at the same time that she stands apart and weaves wonderful adventures for her. Again, realizing her physical inability to shine in athleties, Miss $Z$ pretends that she despises such accomplishments, and fixes her ambitions upon intellectual achievement. As we have noticed, even in this ficld she avoids those sciences which are most suggestive of the hard and unchanging facts of actual existence. Her hatred of convention and disregard 
of accepted standards of conduct suggests also to the psychoanalyst that this furnishes another means of feeling herself to be superior to her fellows; peculiarity is very often mistaken for a sign of genius.

There is little doubt that this extreme intensification of the power motive in Miss $\mathrm{Z}$ is aggravated by an infantile fixation of the libido upon her mother. She has never made any of the later transitions of her psychosexual life which the psychoanalysts recognize as vital for normal social adjustment. As a result she has none of the natural adolescent interest in the opposite sex; indeed men are the greatest source of terror to her, and her only reaction is one of avoidance. Probably this abnormal retardation of the libido is due to the fact that Miss $Z$ was never able to love her father to any great extent, an important step in the development of the love life.

As a result of this pathological condition in her life, when the sex instinct struggled for expression in early adolescence, it was sternly repressed by her dislike of her father. This conflict was symbolized in dreams and in her fears of "the attic people," one of whom was a man that was always trying to slip downstairs and capture her. Her intense reaction to a certain professor is probably occasioned by a slight renewal of this conflict, although her repression of any sexual motive has been so complete that she assigns an entirely different reason for the dislike which psychoanalysis would consider a defence mechanism to cover an unconscious attraction. 
In direct opposition to the Adlerian principle, which woxld interpret the longings of adolescence as the yearning for fuller self-expression, is the Freudian belief that the crux of the matter is the struggle to release the racial impulses from their infantile fixations, in order to transfer them to a more socialized goal. According to this view, the erotic life begins long before adolescence, being present even at birth, the sucking reflex being a form of sexual erethism rather than a manifestation of the instinct of self-preservation, since the lips are essentially an erogenous zone ( 6 ).

Although this statement is entirely one-sided and extreme in its viewpoint, in its more modified form it contains some very significant implications, for it cannot be denied that the early life of the child has a great deal to do with the manner of meeting the adolescent crisis, as Freud and his followers claim. Thus, just as the father becomes the emblem of strength to his son, who desires to emulate him in this respect, so he becomes the ideal man of his daughter's unconscious life, her choice of a husband is determined by this father complex, and she 
can only transfer her libido to a man who possesses some striking resemblance to him. Moreover, there is a tendency to assume a social attitude similar to that created by family. relationships, so that an unhappy home life may embitter the girl against men in general, since if the father is blamed, she develops an ambivalent form of the Edipus complex, and replaces love with hate.

Yet all this is simply a minor impediment to the normal functioning of the racial instincts at adolescence. The colossal struggle is not here; it is not the struggle of the sexual instincts and outer repressive forces, nor yet the endeavor of the w:ll to power for espression, but rather, as Jung more wisely stated, the conflict between thesc two motives which is the real basis of the ardo?scent conflict as it is of the neurosis. Again we turn to concrete illustrations to make the meaning of this statement clear.

Case I. In Miss $X$ the ruling motive of her conscious life, the will to power, was expressed through an insistence upon the equality of woman with man, and a passionate rebellion against wifehood and 
motherhood as wrecking a career. It developed that this "masculine protest" compensated for a feeling of inferiority which had its organic basis in an infantile disease of the kidneys, although the plyysical symptoms of the childhood trouble had disappeared entirely. Nevertheless, she had retained an oversensitive nervous system, so that praise and blame reacted on her whole makeup, both mentally and physically; while her resistance to disease was not always as good as it should have been. This feeling of inferiority had been increased at adolescence by her rebellion against the menstrual function, a rebellion which was tied up with the erroneous ideas of sex relationships which she had gathered from her mother, who represented woman as the sufferer at the hands of the brutal male. At the same time, there was established a sense of social inferiority to accompany the biological one, for she had found herself possessed of an exceedingly plain face and figure, as kindly relatives never failed to point out, and her awkwardness was emphasized by the conservative styles imposed by her mother.

Miss X's attitude toward men was a strange mixture of fascination and aversion, a reproduction of her feelings for her father, which had been strongly ambivalent. As a child, she had loved him as the donor of toys, but after his death she had come to hate him as she grew older and realized the suffering he had caused her mother. Her mother encouraged this attitude. The daughter extended the family situation to the social situation, and saw in man only 
a tyrant who used woman to satisfy his own passions, at the same time refusing her freedom for individual development. In spite of this hostility, Miss $\mathrm{X}$ could not conquer a certain unconscious attraction to the other sex, and to reassure herself was forced to double her protestations of aversion.

At the age of 21 Miss $\mathrm{X}$ learned for the first time the definite facts of sexual intercourse, and at the same time became conscious of her own sexual longing through erotic dreams. Indignant that she had so long been made the victim of the tradition of womanly ignorance, she now extended the tyranny of man to the ethical realm, and averred that he had set up a double moral standard solely for his own convenience, and with utter disregard of feminine happiness. Hence she formulated the doctrine, in imitation of Ellis, Forel and Jones, that marriage was a mere convention, and love was the only true sanction for sex relationships.

A second unconscious motivation for the acceptance of this doctrine of economic independence and disregard for conventional standards, was the fixation of her awakened libido upon a man whom she knew was not in an economic position for marriage, although she felt that he was attracted to her. The influence of this motive was apparent in the fact that she always sought to express her views in his presence, and was quite provoked when he attempted to controvert them. It was at the critical moment when she had all the adolescent passion to prove her beliefs that another man came into the case. 
The seeond man was much younger than Miss $\mathrm{X}$, but encouraged all her views, and gave her the unstinted praise which she had been denied in her home life. He appeared as the ideal and hero of her dreams of a lover, one who should have the same moral eode for one sex as the other, and who should love as deeply outside the marriage bond as inside it. The proposal of a seeret liaison troubled her, however, for all her dreams of unconventionality had involved open defiance of traditions, and had given her an anticipatory thrill of power as she felt herself not only able to think unhampered by convention, but capable of forcing society to admit the correctness of her views by the illuminating guidance of her example.

Fortunately for Miss X, circumstances separated her for a time from her lover, and without his support the old feeling of inferiority returned, and she began to doubt her ability to cope with society onee she had definitely entered upon an unconventional relationship. Yet her work no longer satisfied her, for all her dreams of a career had been swept away in the tide of her awakened love-life, and she cared to live only for her lover.

There followed six months of mental conflict, with only one desire paramount,--the longing to escape the neeessity of a decision in suicide. It was the old introversion of the will to live, or life force. Finding the stern realities of life too hard to grapple with, Miss $X$ longed to approximate the peace of the maternal womb in death. The one conviction which aided her to resist this abnormal impulse was a sense 
of duty to her mother. Then a trivial incident suggested that she might have bcen mistaken in her lover's affection. Instantly the old feeling of inferiority and the ambivalent attitude toward men returned. Hate triumphed over love momentarily, and there came an overwhelming desire to hurt her lover and thus satisfy her thirst for power.

In order to accomplish both purposes, Miss X now announced her intention of marrying another man who had come into her life, and actually attempted to resign herself to the loss of her work and the idea of home life. But a slight humiliation, fancied or real, at the hands of the second lover, roused the old ambivalence, and terminated the second affair.

Although by this time Miss $\mathrm{X}$ was convinced that she had been mistaken about the first lover, and her love for him had returned, the fear of a rebuff (the inferiority motive again) restrained her from making any adrances toward a reconciliation. There became necessary the finding of some means of sublimation for her sexual nature, and at last Miss X chanced upon the compromise which served to solve the long conflict between that motive and the will to power. Long since, the genetic Weltanschauing had become a spur to her imagination, but now she came to feel it as a real religious emotion, to feel herself one with the human race, and to let her love flow out to them instead of focussing it on one person. And in the feeling that she was only a tiny part of that whole, organic unity, the sense of her own imperfections became less oppressive. In ereative artistic work she 
found once more the satisfaction of the creative emotion which gives the intoxicating sense of power that the mystics of old felt in their eestasies; and at the same time, the work became a sublimated outlet for her sexual energy, now turned into proper channels to cmerge as a highly socialized product.

Case II.* If Miss $\mathrm{X}$ appears to be a slightly neurotic type, and hence predisposed to undergo the adolescent conflict with undue severity, Miss $\mathrm{Y}$ is entirely the opposite. Of obviously excellent physical makeup, she is caught in the toils of the same struggle between love and ambition.

Althongh there was nothing in Miss $\mathrm{Y}$ 's physical life to form the basis of a feeling of inferiority, certain circumstances in her social sitnation caused her an undue amount of humiliation during the critical period of her carly adolescence. From a home where she had been petted and spoiled to the utmost, she was sent in her early teens to a convent, where her irreverent attitude, due solely to carelessness, often brought rebukes from the gentle nuns, and filled the wilful givl with agonies of shameful emotion when she was sent to the priest to confess her sins.

In the holy atmosphere of the convent, with its emphasis upon purity of mind and heart, the vague restlessness and physical longings, which took definite shape only in erotic dreams, oppressed the sensitive girlish spirit with a sense of unpardonable sin. She did not understand all that her dreams and reveries

* Case VII, Chapter II, shows Miss Y's own attitude toward ber problem. 
implied, for sex was a sealed book to her, with her convent education, but she felt sure that if the nuns knew her heart they would turn away in horror to find it so black. And so at seventeen she left the convent, still uninstrueted in the simplest details of the sexual life and of the act of procreation, but bearing a sense of secret sin, and hating the nights which came with the wicked dreams that she believed to be wrong but could not prevent with all her prayers.

It is quite logical to conclude that this unsatisfied sexual curiosity was one of the unconscious motives which led Miss $\mathrm{Y}$ to choose the profession of nursing for her life work. Here, too, in a life of service second only to that of the nuns in usefulness, was an outlet for the repressed mood of repentance and desire to atone for the secret sin which even yet she did not. understand. If there were other motives than these in her conscious life, we may be sure that they were no stronger than these unconscious impulses which impelled her to enter into training at the Hospital.

For a long time the other nurses could not believe in the reality of the new probationer's ignorance, but once convinced, they set to work to enlighten her along the lines of sex instruction. The courses which were a part of her training served the same purpose, and the care of patients and companionship with various doctors completed her theoretical knowledge of the subject.

It was now that the real struggle between Miss $Y$ 's sexual nature and her ambitions and love of work 
began. Being exceedingly young and attractive, she had no lack of opportunities to gratify her longing for love, both in marriage and in unconventional relationships. Yet always there seemed to be an obstacle which would intervene whenever she had apparently reached a decision.

In the one case, when Miss $\mathrm{Y}$ considered marriage, there was involved the necessity of relinquishing the work which both for its own sake, and as a satisfaction for the unconscious motives mentioned above, had become a vital part of her life. And so she put off her suitors with evasive replies, unable to give them definite answers because she was unable to make any real and lasting decision in her own mind.

On the other hand, whenever Miss $\mathrm{Y}$ decided to accept some unconventional proposal, which offered satisfaction of her sexual needs at the same time that jt permitted her to retain her independence and her work, the old religious protest would invariably erop out, and at the last moment she would turn away from her lover with the ery that it was a wrong thing they proposed to do.

In this dilemma, Miss $\mathrm{Y}$ turned to homosexual relationships with other girls, while she sought to gain time to choose between the two alternatives proposed above. This means of obtaining satisfaction peculiarly enough seemed to involve no pangs of conscience on account of religious seruples, nor did it interfere with plans and ambitions for her work. At the time of analysis, this homosexual tendency was only in its initial stages, but there was and is grave danger 
of its becoming a permanent habit, since Miss $\mathrm{Y}$ was forced to move before the analysis had becn carried very far, or a final solution had been worked out.

What the ultimate solution of Miss $Y$ 's difficulty will be, therefore, only time can tell. She realizes her danger in yielding to any homosexual impulse, and seems to be turning toward the idea of marriage more and more. Probably the choice of marriage, even at the expense of her work, would be her wisest decision, for it is extremely doubtful whether the emotional traces of her early religious training would ever permit her to enjoy an unconventional liaison without unendurable pangs of conscience.

Case III. In her psychoanalytic study of Charlotte Brontë, Miss Dooley reports an interesting example of the adolescent conflirt as prolonged in genius (4). She characterizes the famous author as being always adolescent, and says that she never reached full maturity, for which reason she is a valuable exponent of some of the deeper phenomena of adolescence.

Charlotte Brontë was aftlicted with a deep feeling of inferiority, due partly to an innate neurotic trend, but over-emphasized by the loneliness of her childhood home, the loss of the mother who might have guided her aright, most of all by her father's teaching that it was not wise to love too well, and by the awe which his aloofness inspired in the hearts of his children. At Rose Head School, at the age of fifteen, a schoolmate told her that she was very ugly, and this was the final touch which made her convic- 
tion of inferiority unalterable, so that she believed all who knew her must pity and despise her.

Strangely enough, she did not develop a strong compensatory will to power, for the racial instincts were too powerful in her life to be sufficiently repressed for that. They did, however, become perverted in the struggle, and were relegated to more or less unconscious levels. Her longing for children was never admitted into her conscious reveries, but the maternal instinct was strong within her soul, and stood revealed in Miss Dooley's analyses of her dream life, and of her writings. That she had a deeply rooted father complex to prevent her falling in love outside the family circle, a detailed discussion of the motives which induced her to sacrifice a career and personal freedom in order to care for her father's declining years shows very clearly. When she did marry it was only at her father's request, and to a much older man. Even then, she died before the birth of her child, too torn by the never-solved conflict of adolescence to finally give herself over to the great vital forces of the race.

Thus the never-ending conflict ran on all her life, so that on the one hand she longed for the outside world where she might achieve personal independence, and allay forever the torturing doubt of her powers due to her feeling of inferiority; while on the other hand, she felt herself drawn ever more firmly to her father, with whom she came more and more to fill her mother's place. It was this dual nature which made her life and work. She had not only an am. 
bitious, aggressive, egoistic side, that rebelled against restraint, but, pulling against it, a passive, fcminine, yielding self, that could not tear itself loose from the bonds of the family life and the attachment of the father-idcal. Could she have freed herself from this Edipus complex, and turned her energies outward to a normal goal outside the family, her books as well as her life, would have been other than they were, for all her writings were but the projection of this inner struggle, which she felt, but could only express through these unconscious symbolisms.

In the light of these concrete studies of the adolescent girl, which might be indefinitely multiplied, we cannot fail to realize that there sometimes occurs an undue prolongation of the psychic struggle which should normally be adjusted without any obvious difficulty. We have seen in the preceding chapter, that the racial instincts are, in the natural course of events, the paramount influences of the girl's innermost being; but we have seen, also, that the egoistic forces may be reinforced by some untoward occurrence, so that the surrender to these deeper motives may be greatly delayed, or even rendered entirely impossible. That this condition is becoming increasingly prevalent 
among the present generation, with its aversion to wifehood and motherhood, and its emphasis upon the egocentric ideals of life borrowed from a man-made set of values, cannot be denied.

The feministic philosophy is expressive of this state of affairs, for it has drifted away from the "Mutterschutz", movement in which it originated, and to the popular mind, at least, means only that woman has set up a rivalry with man in his own domain, claiming for herself the mental, moral and physical freedom which has hitherto been the peculiar privilege of the male sex. In other words, this type of feministic theory is nothing more nor less than a colossal "masculine protest," the Adlerian fictitious power goal of the neurotic, expressing itself in the social mind.

Owen Johnson, in the preface to his novel The Salamander, has very well characterized the adolescent girl who is caught in this mental and social maelstrom, in the following words:

"She comes roaming from somewhere out of the immense reaches of the nation, revolting against the com- 
monplaceness of an inherited narrowness, passionately adventurous, eager and unafraid, neither conscious of what she seeks, nor sure what forces impel or check her. ... New ideas are stirring within her, logical revolts,-equality of burden with men, equality of opportunity and of pleasure. She is sure of one life only, and that one she passionately desires. She wants to live life at its fullest, now, in the glory of her youth. She wants to breathe, not to stifle. She wants adventure. She wants excitement and mystery. She wants to see, to know, to experience. ...

"But always, back of the passionate revolt against the commonplace, back of all the defiantly proclaimed scorn of conventions, there are the hushed echoes of the retreating first generation, there are the old memories, whispers of childhood faith, hesitations and doubts that return and return, and these quiet, suspended sounds make her turn aside, make of her a being constantly at war with herself....W we see clearly two generations.... The third, that coming generation, in which woman will count for so much, where for the first time she will construct and order,-where will it go. Will those who have been salamanders to-day, turned mothers to-morrow, still teach what they have proclaimed, that what is wrong for the woman is wrong for the man, and that if man may experience, woman may explore?" (7.)

Mr. Johnson's statement is very accurate, but he has failed to grasp the fundamental reason which prevents the whole-hearted carrying out of this feministic creed. For in the last analysis, it is not the weight of old tradition, 
nor the force of social pressure alone, which holds the girl back from the actual practice of this beautiful new theory, but a deeper, stronger influence, the rebellion of her own unconscious psychic forces against a step so utterly foreign to their nature. For the power motive, based as it is on organic deficiency, is a pathological phenomenon in the psychic life when carried to the extreme, particularly in woman, who by her entire biological heritage from an illimitable past is irrevocably given over to a wholly different motive, in which love and self-sacrifice and tenderness are the predominant factors.

Kidd has spoken truly when he declares that the fighting male is the ultimate expression of the power principle, while woman is the embodiment of that richer emotional life which founded the family and society, and is now called to the still higher mission of guiding a civilization that has been too long in the hands of men, who have cursed it with continual strife in their lust for conquest (8). As has been stated, woman comes into this magnificent heritage at adolescence; why then should the adolescent 
conflict which has been analyzed in this chapter be so severe? Primarily because the power motive comes more easily into consciousness than the racial impulses, which are more or less submerged in the lower strata of the nervous organism, physiologically speaking, and tend also to be repressed into the unconscious by the whole social mechanism.

Because these deeper racial instincts have so long been unrecognized and unclassified, the adolescent girl's rebellion against the influences which tend to cramp her development is misguided by the adoption of a false set of standards, so that instead of seeking an expression of her own peculiar nature, and making her own unique contribution to the race, she has sometimes attempted to follow the man-made path instead of blazing the trail for herself. Only when she awakes to the fact that her rôle in the world order is as primeval and significant as man's; only when she solves the conflict within her soul by yielding completely to her deepest emotional nature, will she achieve the proud position for which she has been longing, and find herself forming a part of the dual power 
which is needed for racial salvation,-a power in which the quick sympathy of woman supplements the slower intellectual guidance of man. And it is only as she attains this position which is so entirely in harmony with her whole being, that the adolescent conflict, in the individual and in the race, will be finally and rightfully solved.

\section{BIBLIOGRAPHY FOR CHAPTER III.}

1. Adler, Alfred. The Neurotic Constitution. 456 pp. Moffat, Yard. N. Y., 1917.

2. - A Study of Organ Inferiority and Its Psychic Compensation. 86 pp. Jour. Nerv. \& Ment. Disease Pub. Co. N. Y., 1917.

3. Bashkirtseff, Marie. Journal of Marie Bashkirtseff. 825 pp. Rand, MaeNally \& Co. N. Y., 1890.

4. Dooley, Lucile. Psychoanalytic Study of Genius. Part

II : Charlotte Brontë as a Type of the Woman of Genius. Ph.D. dissertation, Clark University.

5. Ellis, Havelock. Sex in Relation to Society. $656 \mathrm{pp}$. Davis. Philadelphia, 1910.

6. Freud, Sigmund. Three Contributions to the Sexual Theory. 91 pp. Jour. Nerv. \& Ment. Disease Pub. Co. N. Y., 1910.

7. Johnson, Owen. The Salamander. 529 pp. BobbsMerrill. Indianapolis, 1914.

8. Kidd, Benjamin. The Science of Power. 306 pp. Methuen. London, 1918. 


\section{TIIE ADOLESCENT GIRL 115}

9. Yoakum, C. S. \& Hill, Mary C. Persistent Complexes Derived through Free Associations: Miss Z's Case. Jour. Ab. Psy. V. 11, 1916-17. Pp. 215-257; 396408. 


\section{CHAPTER IV}

\section{THE SUBLIMATION OF THE LIBIDO}

Man more sexual than other animals; Religious and social repressive factors; Vicarious efferent outlets for sex tension; Seott on sublimation; Don Marquis' poem; Significance of sublimation for adolescence; Pedagogical applications; The rôle of sublimation in the solution of the adolescent conflict.

Just as the psychoanalysts have been the first to imply the essential nature of the adolescent crisis, so in their doctrine of sublimation they have given us at least one adequate solution of the mental conflict which it involves. For the inherent tendency of the sexual instinct to transmute its energy into other channels, - to "sublimate" itself,-is never more marked than during the period of adolescence. In order to fully understand the significance of this for the girl's life, we must make a wide digression at this point, and going back into the field of genetic psychology, trace the development of the 
innate tendency of the reproductive instinct to find an outlet through the vicarious channels of art and religious activities.

"In the gray dawn of human life," says Margaret Skyde (38: p. 9), "everything was quite simple. Man and woman were as simply a part of nature as were other members of the animal kingdom. The sexual impulse was nothing more than a powerful instinct, very like hunger, thirst, the desire for sleep. Its satisfaction brought a sense of physical well-being much like the satisfaction of other needs."

Little by little, as the ages passed, all this changed. According to genetic psychology, when our first progenitors came down from the trees, and took to living in the caves, there were certain conditions in their life which brought the function of sex from an instinctive to a conscious level. The bi-pedal position, the loss of a hairy covering, the intimate throwing aside of garments in the warmer atmosphere of the cave dwellings, the use of the hand for sexual stimulation, all tended to focus the attention on the organs of reproduction and to emphasize sex as it had never before been emphasized. 
It has been suggested that there followed a stage of human evolution when man wallowed in the mire of sensualism, until he had exhausted his racial vigor, and was like to sink back below the animals whence he had emerged. But an all-wise nature had not endowed him with so vast a fund of energy in order to see it thus go to waste, and in the end its irresistible power became its saving quality.

In order to understand how this came about, we must fully realize the fundamental tendency of the human psyche to project its subjective emotional states upon whatever object of the environment has acted as a stimulus to arouse the feeling. That deep affective elements can be excited by very casual stimuli is explained by Jung (25), Carpenter (4), and Crile ( 7 ) from the genetic viewpoint; but early man, lacking this scientific data, concluded, as Crawley (6) and Sumner (43) have pointed out, that this emotion was due to some superhuman power residing in the stimulus itself. Thus, we can understand that man came very early to worship the great sun-god because there had been stamped upon the neural tissues a long series of 
racial patterns connected with light stimuli, motor patterns no longer of survival value, so that their stimulation no longer results in a reflex action, but is ushered into consciousness in the form of an emotional state. Carpenter has observed that there is a desire to personify whatever has awakened these racial memories and brought us into touch with the greát subconscious mind of the race, and that herein we have the origin of all the deities which man has set up for himself in the long ages of his development (4). Not only the sun, but the trees, rain, rocks, and every natural object, had played an important rôle at one time or another in the life of primitive man, so that there grew up a kind of nature worship, which regarded them as inhabited by supernatural beings, or pervaded by some spiritistic force, like the "mana" principle of which Durkheim makes so much (45).

The connection between this tendency and the rescuing of man from the consequences of his overdeveloped sexuality becomes clear when we remember the universal phallic cult or religion that swept over the world at one time, 
and recollect the elaborate system of sexual taboos and magic ceremonials that became interwoven with the social customs of the ancient races. Having reached a state of mind where all his thoughts were sexually inclined, man came to compare every conceivable external object with his own reproductive structures, so that finally every part of his environment came to be a male or female sexual symbol $(23 ; 24)$.

It was but a short step from similarity of stracture to similarity of function, and to the identification of all the creative processes of nature with the act of human procreation, as Westrop (48) and Weir (46) have remarked. This worship of the creative principle, thus conceived as having its supreme expression in the reproductive activities of man, imposed certain ceremonial restraints upon excessive sexual gratification, and thus worked incalculable good to its followers, until it became decadent, and its rites degenerated into orgies of licentiousness. By the time this had happened, however, its mission had been accomplished, and other repressive forces had taken its place in controlling the instincts and impulses of mankind. 
The second factor which entered into the control of the sexual function was a more direct result of the supposed state of mental and physical exhaustion which had resulted from his excesses, and involved a complete change in his attitude toward woman. Originally she had been his mate, his free and equal comrade in the precarious struggle for existence; then she had become the object of his passions, albeit an unwilling one, for not easily did she give up her inborn periodicity of function to satisfy his desire; in the third transition, she roused the old desire, to be sure, but it had become an ambivalent emotion, in which fear was an equally strong component, for were not all his sufferings due to contact with her (6)?

This ambivalent feeling may have been only partly due to the belief that she had infected him with bad magic. which was the cause of prolonged depression after too close contact with her, a view which Crawley and Frazer support by the evidence that most primitive tribes have strict taboos on intercourse before battle or the hunt, in order to avoid being overcome by bad magie, which induces womanly weakness $(6 ; 12)$. 
Elliott Smith thinks this ascribing demonic powers to woman was due also to man's discovery that he was the impregnating being in the great act of procreation, in which he conceived himself as furnishing the living spirit of the new individual, while woman contributed only the wicked fleshly body in which this divine essence was to exist (40).

Whether one or, as is most probable, both of these factors entered into the determination of man's attitude toward the female, the result was of immense importance to his mode of living, for there grew up an elaborate system of taboos which restricted sexual intercourse still further, and thus acted as an auxiliary to the religious control which had also been imposed upon the procreative life.

There was still another controlling agent which served to coerce the sexual instinct from too free an expression-the horror of incestuous relationships which has been so much emphasized by the Freudian school. Westermarck says this horror was instinctive and inborn (47), but the psychoanalysts take issue with this statement. The psychoanalytic theory has 
been most elaborately developed by Otto Rank, who has devoted a whole volume to an exposition of his viewpoint, which is that incest became taboo only as continued inbreeding led to a degeneracy which the savage mind interpreted as a sign of divine anger. In proof of this later development of the incest horror, he cites the customs of certain primitive tribes, in which incest is not at all or only partially condemned; the ancient religious orgies which set aside the relationship taboo and allowed indiscriminate sexual intercourse; and finally analyzes a great number of literary productions, including the works of such men as Shelley, Goethe and Schiller, to show that their guiding motif is the suppressed love for mother or sister (32). The Freudian proofs of the incest-desire are borrowed from analyses of abnormal patients who are often found to possess "father" or "mother complexes," which are always considered specifically sexual in nature, although Ferenczi (11) and Jung (25) have defined this clinging to the parent as a fear reaction, based upon the neurotic inability to meet the crises of independent life. 
As these various social and religious factors united to control the reproductive energy, it was not simply repressed, but was deflected into new efferent channels of vast import for the progress of mankind. The whole trend of organic evolution had been a long-circuiting of the sexual process, from the specialization of germinal tissue and the perfection of the reproductive organs to replace the simple conjugation of protozoan life, to the development of an elaborate set of secondary sexual characters, of epigamic colors, and courtship plays, as described by Darwin (9). Just as in other animals, the relative lack of sexuality in the female had caused the overabundant energy of the male to overflow into the songs, calls and plays of the mating season, which were preserved by natural selection because they served to rouse the more passive female, until in many cases they were dissociated from their sexual sources, and came to be valuable in themselves, so in man the reproductive energy sought other means of expression than its primary biological one.

Thus the emotional tension of man found re- 
lief through channels made facile by a long phylogenetic past, so that tied up with the more crudely sexual rites of his Phallic religion, such as the sacrifice of virginity to the gods, and the orgiastic rites connected with the sowing of the harvest, came a more spiritualized form of the same principle, half sexual and half magical in nature, apparent in the songs and dances which were the chief employment of primitive people, as Felix Krueger notes (26) and which, originating as an outlet for sex tension, passed over into conventional ritualism, and became a part of the folkways, regarded by the people as most potent of charms to secure prosperity and safety. Traces of this sexual element in primitive agricultural ceremonies are found to-day, as Skeat has reported among the Malays (37), Squire in the British Isles (42) and Grimm among the Teutonic peasantry (17). Frazer, too, in The Golden Bough, has collected a series of these magical incantations and activities in which the sex factor was once predominant. (13.) But long after their source in sensualism and superstition was forgotten, the song and dance, the verse and picture-making, thus begun, 
continued to serve as an effectual outlet for the surplus energy of the human race as it strove to make these arts ever higher and more beautiful, until they came to be cultivated for their own sake and the sexual motif back of them was entirely submerged in the depths of the subconscious psyche.

Colin A. Scott, in a paper on Sex and Art, has traced the evolution of this process so clearly that it is well worth while to epitomize his article at this point. (35.)

The primordial source of the sex passion as of the higher creative impulses with their pleasurable affective tinge, is "the fundamental quality of erethism found in every animal cell. . . The amøoboid movements of the Protozoa show this function in operation indifferently at any portion of the body and before the differentiation of any subservient structure, while the alternate erection and flaccidity of the metazoan cell, shown by Mosso, Hodge, and others to depend upon nutrition and to correspond to states of aetivity and fatigue, carry this function into every part of the most highly developed organism." With the gradual differentiation of tissues and organs and their specialization for functions originally performed by the whole unicellular organism, this ercthism is localized in the reproductive organs and the secondary erogenous centers,-lips, breast, etc.,--with which the 
former are connected by the sympathetic nervous system. In the higher animals, more specifically the mammals and especially man, the central nervous system is also involved in the incitation and inhibition of the sexual desires, so that the whole neural tissue finally becomes highly sensitized to register the organic sensations from the sexual centres, and becomes itself permeated with similar erethic tendencies.

"The characteristic feature of sex is the law of irradiation, which might be stated as follows:

"Starting from the act of copulation, the sexual instinct tends to widen and become more complicated, until the whole of the organism is involved in its activity.

"This law is a necessary outcome of specialization and the erethism of sex. Sexual union is properly the climax of an erethism which involves the whole economy, but more especially those special organs of radiation, the brain and nervous system."' It is to the end of spreading and enhancing this erethic quality that the lower animals have developed colors, odors, calls, etc., which act as powerful stimuli, and have been favored by natural selection since they have been important factors in insuring the continuation of the species. In the same way various activities have been fostered, as the fighting impulse, which means triumph over rivals for the individual possessing it in the highest degree, and the art of courtship, which is of value as a means of arousing the more passive female, and securing her consent to sexual union. Very often, these activities become 
more or less dissociated from the sexual instinct pure and simple, and are turned to other ends of even more vital issue to the race. A good example of this is the evolution of the parental feeling in the fish, in many species of which the male not only fertilizes the eggs deposited by the female, but guards them until hatched, the original impetus to fertilization having been prolonged to form the matrix of the parental instinct which becomes so complicated in higher members of the animal kingdom.

In man, this tendency to dissociation has been a prime factor in the growth of art, music, literature and other intellectual activities. From the all-pervading idea of sex which once obsessed the human species, and found expression in the fetishisms to which the neurotic of to-day reverts once more, and in the phallic cults personifying the universe sexually, there came into being an asthetic emotion which resulted in a love of the beautiful apart from its existence as an erotic stimulus, while an increasingly vague symbolization in worship permitted the development of a religious ardor in which the sex element was no longer obvious, though still the moving force. So, too, the movements and calls of the courtship period were carried over as pleasurable in themselves, and were woven into the mores of the people in dance and song. Thus the neural erethism originally inseparable from the sexual erethism became almost as intense a phenomenon as the latter, so that intellectual creativeness came to be permeated with the 
ecstatic enjoyment which had formerly been confined to the biological level, and formed a distinct end in itself.

In a simpler manner, unhampered by the technicalities of scientific discussion, the poetic intuition of Don Marquis has also expressed the fundamental unity of the sexual emotion with the appreciation of beauty and the worship of God.

\section{THE NAME}

It shifts and shifts from form to form,

It drifts and darkles, gleams and glows;

It is the passion of the storm,

The poignance of the rose;

Through changing shapes, through devious ways,

By noon or night, through cloud or flame, My heart has followed all my days

Something I cannot name.

In sunlight on some woman's hair,

Or starlight in some woman's eyne,

Or in low laughter, smothered where

Her red lips wedded mine,

My heart hath known and thrilled to know,

This unnamed presence that it sought;

And when my heart hath found it so,

"Love is the name," I thought. 
Sometimes when sudden afterglows

In futile glory storm the skies, Within their transient gold and rose

The secret stirs and dies;

Or when the trampling morn walks o'er

The troubled seas, with feet of flame, My awed heart whispers, "Ask no more,

For beauty is the name!"

Or dreaming in old chapels where

The dim aisles pulse with murmurings

That part are music, part are prayer-

(Or rush of hidden wings)

Sometimes I lift a startled head

To some saint's carven countenance, Half fancying that the lips have said,

"All names mean God, perchance!"

(Don Marquis in Dreams and Dust.)

The importance of this substitution of a higher nervous erethism for the more primitive sexual form cannot be overestimated as it applies to the life of the adolescent girl. For adolescence, in either sex, is a period of intense mental activity, and contains almost unlimited possibilities for the development of the higher intellectual and emotional processes. The fire of sex burns high, and being wisely repressed by social traditions and customs, flows easily 
into channels which have become normal neural pathways through the long generations when the young luman race was evolving and perfecting the arts of dance, song, poetry, and picture-making. Jung, in his analysis of Miss Miller, which he aptly named Wandlungen und Symbole der Libido, showed how the awakening sexuality of this young girl was expressed in ways which had been laboriously worked out in the history of the race, so that her poems were simply another version of the ancient myths created by the same human longings in other days. (25.)

The adolescent longs for the great emotional experiences to which the awakening sexual life inclines, but having no real experience by which to gauge an idea of the specific sensation for which the being craves, finds complete satisfaction in the erethic glow of religious ecstasy or in the æsthetic appreciation and creative ardor which surrounds intellectual work, whatever the form it takes. Especially is this true of the girl, for much less than the boy does she realize that her vague longings and aspirations have anything even remotely sexual in their compo- 
sition, and turns so much the more readily to the emotional outlets of religion and art as a means of satisfaction.

The pedagogical significance of this erethic quality of the adolescent mind cannot be overemphasized. With our present fetishistic attitude toward all sorts of educational schemes which make for economic efficiency, with our emphasis on vocational guidance and business training, we are apt to forget those other things which a well-balanced educational system must inculcate, a strong moral fibre against the discouragements and temptations of daily life, and a capacity for long and sustained labor which the knowledge of one's trade alone cannot give. In the plastic stage of adolescence will be formed the habits which will govern the later life, and it rests with the parent and teacher to so guide the youthful minds that this innate tendency to utilize the sexual energy in more socialized forms of erethism shall be expanded to its utmost limit. If the habit of thus calling upon the racial powers inherent in individual life be formed at this time, we shall find in later life, when we are called upon to carry out tasks 
which seem beyond our strength, that we have access to an unsuspected store of energy, which must remain untapped for these higher purposes unless in adolescence its strength has been turned into channels which a long evolutionary history has indicated.

Sexual hygiene also demands the accomplishment of this sublimative process, for there is no surer way to protect the adolescent from temptation then to drain the waves of sexual emotion into those channels which have proven to be satisfactory substitutes for the procreative act in the experience of the race. Unless this prolongation of adolescence and the sublimation of its crude instinctive forces be accomplished, there can be no hope of attainment to a general level of culture where the powers of the human race will be used to the best social advantage, nor will there be in individual existence any taste of these supreme pleasures which are the joy of the creative genius, and of æsthetic and religious emotions.

At adolescence, as a recent Spanish author, Señor Mercante, has emphasized, there should be a radical change in tho whole educationat 
program. The time for drill is over, now; the soul of youth is essentially active, and possesses a craving for excitement that will not be denied, but finds satisfaction in devious ways when home and school are not wise enough to meet its needs. The imagination runs riot, too, and must be guided into creative channels, lest it waste its energies in delusion and dream. Here, artistic talents and the study of literature play an important rôle, for the æsthetic emotion on either the creative or more passive appreciative side provides the natural field for the play of fancy.

"In art," says James Mark Baldwin, in his Genetic Theory of Reality, "the imagination finds its synthetic and perfect rôle; the things of knowledge and will, taken up by the imagination, fuse in the immediacy of the values of feeling, and the two great currents of affectivism, the mystical and rational, fall together" (2:p. 311).

Again, the newly awakened gregarious nature of the adolescent requires a sympathetic interpretation as the prime requisite of literary instruction, for there exists within the whole being 
a desire to enter into the myriad life of the race that is gone before, and the heroes and heroines of literature offer one meaus of realizing this wish, in so far as the teacher is skilful enough to encourage the child to suffer and enjoy vicariously through them. As Mrs. Heniger has pointed out in her recent publication, The Kingdom of the Child:

"It is far more important to universalize the. sympathies of a child by bringing him into personal relations with characters in books and plays than it is to have him know that sucb or such a verse is written in iambic tetrameter. . . The instinct of youth for the beauty and vividness of expression, boyhood and girlhood's intuitive feeling that behind the message a human soul exists, and youth's desire to reincarnate the soul through the messag*e, all furnish us with our best guides on the pathway of literary instruction." (22: pp. 105-106.)

It is this humanistic element which must pervade the entire high school curriculum. The girl must no longer be molded into the rigid school system, but the educational plan itself must become plastic, and easily adaptable to the 
fundamental nature of adolescence with its ever varying needs. We have spent much valuable time and energy in our emphatic denunciations of kultur, and acclamation of culture; let us utilize all this emotion in the remodelling of our secondary schools in accordance with the ideals thus loudly proclaimed.

In connection with our technical laboratory work in physics or chemistry, the student must be infused with a sympathy and admiration for the keen minds and unique personalities which are comnected with the development of these sciences. History must be taught not as the rise and fall of empires, but as the thrilling, glowing story of the human race, prefacing the tales of Greece and Rome with an account of the origins of mankind, and his primitive life and social organizations. In the translations of languages, not the grammatical accuraey, but the spirit of the author and his characters, should be the chief end and aim, while even mathematics might be somewhat illuminated by little diversions into the biographies of those who first formulated its principles. The adolescent love of nature should be reinforced, not dulled, 
by the study of biology, as the science of natural life activities, and of the evolution of the stirp. Thus presented, it becomes most important, for in this manner it becomes the foundation for the great cosmic view which sees man as one with all existence, and which, in its spirit of fraternity, is the ultimate form of religious emotion.

Just as the boy has a motor outlet for his energies in his games, which are more or less a conventionalized recapitulation of old racial habits, so the girl must be furnished with similar efferent channels. The girls' camps movement is an expression of the realization of this necessity, but these serve only for the short summer season. In school time, the folk dances, rightly treated, are the ideal physical activity, but they must never be instituted as mere exercises. The girl must know the origin and meaning of each, so that she enters into its very spirit, and creates her dance as she moves in rhy thmic cadence to its music. (8.)

All this is the keynote of the training which is proper for the adolescent girl, as for the boy,-a vitalization of the studies which have 
long been dished up as dead sea fruit, and a utilization of the eager creative imagination of youth in this life-giving process. Herein we are accomplishing a double purpose, since at the same time that we are establishing the habit of sublimation and developing the higher neural erethisms to their utmost limit, we are also fulfilling the more utilitarian end and aim of education, and fixing the facts we are attempting to impress upon the childish mind more firmly than ever before.

But in a still deeper way is it necessary to cherish and encourage the sublimative processes, for only here may be found an adequate solution of the conflict which tears the adolescent soul. For at the same time that all these activities which were developed in the youth of the race, and which are most apparent in the youth of the individual, serve to satisfy the sexual desires, so, too, they gratify the will to power, and the egoistic tendencies to an equal or even greater degree.

There is no doubt that just as the sexual ecstasy releases the individual from all consciousness of independent existence, with its 
feelings of inability and weakness, so these substitutive activities raise him above the plane of everyday life with its impress of impotency and inferiority. It is the ego that rejoices in the applause after the dramatic representation; it is the sense of power that is fulfilled by the contemplation of a finished poem or picture, a sense which is enhanced still more if praise be given by others who see the work; and the religious emotion is perhaps more powerful than any other to lift the devotee above and beyond the limitations of his own narrow personality, as the mystics of old knew when they sought to revel in the ecstatic feeling of being united with God himself.

In the final analysis, however, it is not the praise of others which is the greatest satisfaction of the desire for power, it is the inner feeling of strength and force which sweeps away the oppressive sense of inferiority and limitation. And this subjective state is never more potent than in the glow of the neural erethism which is the basis of the religious or æsthetic ecstasy. The savage felt the thrill of this inner power, and believed it to be the expression of a 
superhuman force, manifesting itself in his individual existence. To-day we know that it comes from the subconscious energy of the race, and is a part of the great élan vital which has been accumulated and passed on through the germ plasm of countless generations; but as we come in contact with it and feel its thrilling force, we, too, know that we bear within us a strength beyond our own.

Algernon Blackwood, in his Garden of Survival, has voiced this modern conception in almost poetic language: "Behind every thrill of beauty stand the countless brave souls who have lived it in their lives. They have entered the mighty rhythm that floats the spiral nebulæ in space, as it turns the little aspiring nautilus in the depths of the sea. Having felt this worship which is love of beauty, they are linked to the power that drives the universe toward perfection, the power that knocks in a million unadvertised forms at every human heart, and that is God.",

It is in this power of sublimation, which satisfies the individual the more fully as it absorbs more and more of the great fund of racial en- 
ergy, and thus sweeps each little personality into the larger organic whole of all humanity and of the universe, that we have the temporary solution of the problem of adjustment which makes life so difficult for the adolescent girl. For some, indeed, it must become a permanent solution by being infinitely broadened and woven into the work and social life, for to some will be denied the biological expressions of the womanly nature in the great functions of love and maternity.

\section{BIBLIOGRAPHY FOR CHAPTER IV}

1. Abraham, Karl. Dreams and Myths, A Study in Race Psychology. 74 pp. Jour. Nerv. \& Ment. Disease Pub. Co. N. Y., 1913.

2. Baldwin, James Mark. Genetic Theory of Reality. 335 pp. Putnam's Sons. N. Y., 1915.

3. Brown, Sanger. Sex Worship and Symbolism in Primitive Races. 140 pp. Badger. Boston, 1916.

4. Carpenter, Edward. The Gods as Embodiments of the Race Memories. Pp. 259-279. Hibbert Jour. II, 1904.

5. Corin, James. Mating, Marriage and the Status of Woman. 177 pp. Walter Scott Pub. Co. London, 1910.

6. Crawley, Ernest. The Mystic Rose. 492 pp. Macmillan. N. Y., 1902. 
7. Crile, Geo. W. Origin and Nature of the Emotions. 240 pp. W. B. Saunders Co. Phil. \& Lond., 1915.

8. Curtis, Eleanor W. The Dramatic Instinet in Education. 246 pp. Houghton, Mifflin Co. N. Y., 1914.

9. Darwin, Charles. The Descent of Man and Selection in Relation to Sex. 658 pp. Appleton. N. Y., 1903.

10. Ellis, Havelock. Psychology of Sex. Vol. II. 314 pp. F. A. Davis Co. Phil., 1900.

11. Ferenczi, Sandor. Contributions to Psycho-Analysis. 288 pp. Badger. Boston, 1916.

12. Frazer, J. G. The Golden Bough, Part II: Taboo and the Perils of the Soul. $446 \mathrm{pp}$. Maemillan. London, 1911.

13. - The Golden Bough. Part V. Spirits of the Corn and of the Wild. Vol. I. 319 pp. Macmillan. N. Y., 1912.

14. Freud, Sigmund. Totem and Taboo. 265 pp. Moffat, Yard \& Co. N. Y., 1918.

15. Geddes and Thompson. Problems of Sex. $52 \mathrm{pp}$. Moffat, Yard \& Co. N. Y., 1912.

16. —u Evolution of Sex. 322 pp. Seribner's. N. Y., 1901.

17. Grimm, Jacob. Teutonic Mythology. I. 437 pp. Geo. Bell \& Sons. London, 1882.

18. Groos, Karl. The Play of Animals. 341 pp. Appleton. N. Y., 1898.

19. Grosse, Ernst. Die Anfange der Kunst. 301 pp. Paul Siebeck. Freiburg \& Leipzig, 1894.

20. Howard, Clifford. Sex Worship. $167 \mathrm{pp}$. Washington, D. C., 1897.

21. Hirn, Y. The Origins of Art. $331 \mathrm{pp}$. Macmillan. N. Y., 1900.

22. Heniger, Alice Minnie Herst. The Kingdom of the Child. 173 pp. Dutton \& Co. N. Y., 1918. 
23. Inman, Thos. Ancient Pagan and Modern Christian Symbols. 147 pp. N. Y., 1884.

24. Jennings, Hargrave. Phallicism. $29 \mathrm{~S}$ pp. Redway. Lond., 1884 .

25. Jung, C. G. Psychology of the Unconscious. (Wandlungen und Symbole der Libido.) $566 \mathrm{pp}$. Moffat, Yard \& Co. N. Y., 1916.

26. Krueger, Felix. Magic Ritual in Primitive Industry and Agriculture. Am. Jour. Psy. V. 24, April, 1913.

27. Mason, Otis T. Woman's Share in Primitive Culture. 295 pp. Appleton. N. Y., 1859.

28. Mercante, Victor. La Crisis de la Pubertad. Cabaut y Cia. $437 \mathrm{pp}$. Buenos Aires, 1918.

29. Parke, J. R. Human Sexuality. 476 pp. Professional Pub. Co. Phil., 1906.

30. Ploss, H. Das Weib. 2 vols. Grieben, Leipzig, 1913.

31. Poulton, Edward B. Essays on Evolution. $479 \mathrm{pp}$. Clarendon Press. Oxford, 1908.

32. Rank, Otto. Das Inzest-Motiv in Dichtung und Sage. 685 pp. Franz Denticke. Leipzig nnd Wien, 1912.

33. - The Myth of the Birth of the Hero. 94 pp. Jour. Nerv. \& Ment. Disease Pub. Co. N. Y., 1914.

34. Roceo, Sha. Ancient Sex Worship. 65 pp. Hudson. N. Y., 1889.

35. Scott, Colin A. Sex and Art. Pp. 153-226. Am. Jour. Psy. VII, 2. Jan., 1896.

36. Silberer, Herbert. Problems of Mysticism and Its Symbolism. 451 pp. Moffat, Yard \& Co. N. Y., 1917.

37. Skeat, W. W. Malay Magic. 685 pp. Macmillan. N. Y., 1900.

38. Skyde, Margaret. From the Gray Dawn of Life. 51 pp. Beiter. Baltimore, 1918. 
39. Smith, Frederick. The Higher Powers of Man. 232 pp. Herald Pub. House. Lamoni, Iowa, 1918.

40. Smith, G. Elliott. Primitive Man. 50 pp. Proceedings Br. Acad. V. 7. Oxford Univ. Press. London, 1916.

41. Spurell, H. G. F. Modern Man and His Forerunners. 192 pp. G. Bell \& Sons. London, 1917.

42. Squire, Charles. The Mythology of the British Islands. 446 pp. Blackie \& Son. London, 1905.

43. Sumner, Wm. G. Folkways. 692 pp. Ginn \& Co. Boston, 1907.

44. Wallaschek. Primitive Music. 326 pp. Longmans, Green \& Co. N. Y., 1893.

45. Wallis, W. D. Durkheim's View of Religion. Pp. 252 . 267. Jour. Relig. Psy. VII, 1914.

46. Weir, James. The Psychical Correlation of Religious Emotion and Sexual Desire. 338 pp. Courier-Jour. Printing Co. Louisville, Ky., 1897.

47. Westermarck, E. A. History of Human Marriage. 644 pp. Macmillan \& Co. N. Y., 1901.

48. Westropp, Hodder M. Primitive Symbolism in Phallic Worship. 65 pp. Geo. Redway. London, 1885. 


\section{CHAPTER V}

\section{PATHOLOGICAL MANIFESTATIONS OF LIBIDO IN ADOLESCENT GIRLS}

Hysteria,-Freudian statement; Healey on delinquency of hysterical girls; Mediumship in adolescent girls; G. S. Hall's study of a budding medium; Dissociated personality: Pathological lying; Religious forms of hysteria; Hauptmann's Hannele and St. Theresa: Jung's theory of Dementia Præcox; Case study of D. P. by Dr. Lucile Dooley; Borderline cases; Therapeutic measures.

If the tendency of the sexual energy to overflow into substitute activities were confined to higher artistic and religious sublimations, the $\Rightarrow$ problem of the adolescent girl would be much simplified, but unfortunately, the erotic vicariates, under certain conditions, become distinctly pathological in character, and may be injurious to both the individual and society. The adolescent period thus becomes a critical time in the girl's life, for recent psychological and medical studies have shown that the beginning of cer- 
tain mental diseases, such as hysteria and dementia pracox, are coincident with the onset of puberty, while a host of minor abnormalities are most likely to make their appearance at this age.

The biological basis for the incidence of these pathological phenomena is the inheritance of an unstable and oversensitive nervous system, which is not able to endure the strain of the mental conflict which is the psychic side of adolescent phenomena. But in most instances, it is the nature of the environmental stimuli that determines whether the conversion of the sexual energy shall be upward or downward. It becomes necessary, therefore, to consider bricfly the abnormalities of the mental processes peculiar to adolescence, with a view to perceiving the remedial and preventive measures necessary to conserve the health of the individual, and utiTize the energy thus going to waste for social purposes.

Perhaps the most prevalent type of adolescent abnormality is the hysterical symptom, which may assume any one of many widely differing forms. In its commonest manifestation 
it is characterized by a conversion downwards of the libido, so that its energy is expressed through some irrelevant activity, which by obscure associative processes has come to be a vicariate for the real psychic motive, which Freud claims is always an erotic desire. In proof of the latter statement, Freud has collected a series of detailed analyses of hysterical girls (11), in which he shows the distinctly sex- ual etiology of the hysterical symptoms. The sexual trauma is sometimes of a physical nature, consisting of childish experience, brutal assault, etc., but more often is of a purely psychological character, and is caused by premature or too long delayed sexual enlightenment, secured in an unpleasant manner, or in the bestowal of affection where social sanctions forbid.

In any case, the crucial feature is the attempt to forget the experience, and everything associated with it, so that it becomes repressed from the conscious thought processes of the psyche, but being retained in the unconscious substrata of the mind, forms a nuclear center which gathers to itself an increasing energetic 
force as allied experiences are successively repressed and unite with it. The whole "complex" thus formed finally seeks an efferent outlet through some physical symptom, whether it be the hysterical pain, paralysis of some part of the body, or some convulsive motor habit, commonly known as a "tic." For concrete cases which furnish detailed accounts of the hysterical mechanism, the reader is referred to the various psychoanalytic studies of Freud, Breuer, Jung, Janet, and their co-workers.

William Healey confirms the Freudian theory of hysteria when he declares that the hysterical type of girl figures prominently in court in cases of false accusation, and concludes that she is actuated-by the subconscious desire to suffer the sexual assaults of which she complains. (15.) He also shows that the suggestible hysterical temperament tends to solve the mental conflict of adolescence, with its emphasis on the sexual factor, by substituting such criminal acts as lying and stealing for the sexual delinquencies to which bad companions incite. One of the cases which he describes in 
this connection may well be epitomized here. (16.)

Girl of twelve. Fifth grade in school; scholarship good. Not very well physically. Heredity free from insanity, feeble-mindedness and epilepsy. Mother dead; brought up by grandmother. Three years ago began to lie and steal. Questioning elicited the following facts:

"The boy in our street, Sam S., he's about fifteen. Teacher said he shouldn't go to school any more. He said I should take things. I used to see him when I went roller skating, and when I went to the pasture on the prairie with the girl next door for the cow. Sam used to talk to her, too. He asked her to go out in the bushes with him. He used to say bad words to us. Sometimes when I think about the words I get a headache and feel as if I'd got to take things. Never thought that word had anything to do with babies. Couldn't find out anything about babies."

From the investigation of numerous cases similar to this, Healey shows the immense significance of unsatisfied sexual curiosity or improper enlightenment as a factor of the mental conflict which tears the oversensitive adolescent soul, and predisposes to neuroticism or crime. That it may have other effects, equally disas- 
trous, will be apparent in a later part of our discussion.

Aside from the purely sexual factor in the etiology of the liysterical malady, is a motive which is in a sense closely connected with the former, yet which is deserving of separate mention-the desire for attention. In another relation, Adler has emphasized this characteristic of the neurotic affliction, for in no other way, as he points out, can the individual become the center of affairs so easily and permanently. (1.) This is undoubtedly a predominant motive in the incipient stages of the development of those pathological cases whose hysterical temperament is expressed in the weird ability to assume the clairvoyant state, or in the development of mediumistic powers.

Podmore has given a detailed account of the spiritistic phenomena commected with the Fox sisters and many other girls during the last half of the nineteenth century (24), and Barrett, with his investigations of the Creery sisters (5), as well as other scientists have reported interesting cases. From the viewpoint of a causal analysis, however, Pres. Hall's study of 
"A Medium in the Bud"' is well worth a brief review, since it not only shows the typical phenomena of the mediumistic powers, but also makes very evident the hysterical motivations back of them. (13.)

The mediumship of the young girl in question was so much in the incipient stages that she had not yet gotten to the point of losing herself in trances, and showed very plainly that she was influenced by the suggestions conveyed by her interrogators. The matrix in which this nascent mediumship arose shows clearly the mechanisms which went into its development. The girl, who is called Annie, lived in a small country town, more or less isolated from neighbors, because her mother, on becoming estranged from her husband, and being very sensitive to gossip, had withdrawn wholly from the social life of the community. The girl was bright and impressionable; she had done a great deal of miscellaneous reading, and had allowed her imagination to run riot as only adolescents can do, until the world of her reveries had become the realest thing of her existence. Her mother was credited with the possession of spiritistic powers, and was ever on the alert to detect any heredity of these on the part of her daughter. Then came a visit to a famous medium, who insisted that spirits were eager to assume Annie's control and guidance, so that it was little wonder that her adolescent dreams of greatness 
took this shape, and that she began to cultivate mediumistic powers.

Already the girl had formulated a theory that all was prepared among the Heavenly hosts for the fulfilment of God's far-reaching plans, and only the means was necessary for the inauguration of a new era on earth and in IIeaven. And the agent of this great regeneration would be a young girl, with whom the spirits would hold communication, and whom they would lead to be a redeemer of the people. Once these dreams eame to be implicitly and naïvely believed by Annie, it was only a short step to see herself as the chosen instrument of God, a belief which was aeclaimed with enthusiasm and tenderly fostered by her mother. Thus there seemed for a long time no sex motivation, but only an attempt to save the sense of personal value amid the neglect and criticism of her neighbors by the ereation of an inner world which in the magnificence of its far-flung imagery more than made up for all that she missed in the outer reality, from whieh she had thus taken flight. Her only purpose in coming to Dr. Hall seemed to be simply a desire to convinee the seientific world that she was truly the ehosen one of God for the new revelation, and to receive confirmation of her dreams, since she was still tortured by lingering doubts as to their reality.

It was only after the invention of fictitious spirits had proven to the investigators that the mediumship was a simple aceeptation of suggestion, that the erotic element began to appear. The girl insisted in 
her belief in her powers, even after being caught responding to misleading statements time and time again, and her "control" now began to tell the auditors the most intimate secrets of the medium's heart. Apparently under the impulsion of her guiding spirit, and quite without her own volition, Annie confessed that her true motive in asking for the hearings had been the desire to have a certain man of her acquaintance sit at the investigations, in order that he might be impressed with her sagacity and importance. It was because of the cloud the gossip had created, she fancied, that this man proved so indifferent, and she felt sure that if he once saw her with the learned men taking notes as she displays her mediumistic powers, her full worth would dawn upon him. Thus the whole fantasy seemed to have been evolved in order to place her upon an equal footing with the man whom she desired should not regard her as a social inferior, and the basic motive was, after all, no power complex, but the woman's age-old longing for a mate.

After many more attempts to gain the loved one's interest through her spirit communication, Annie became discouraged by her continuous failure, transferred her affections to another lover, who did not believe in spiritism, and discarded her world of fantasy for a pleasanter world of reality.

Closely related to the hysterical temperament is the mental diathesis which makes for dissociated personality. Here, again, the 
correlation between the inception of this strange psychic phenomenon and the onset of puberty is an exceedingly high one. The famous Felida $X$ of Azam's studies was normal till thirteen, after which she showed hysterical symptoms, and periodically fell into a trance, emerging with a new personality, as vivacious as her primary state was gloomy. The alteration between the two states continued for some time, after which the secondary and more pleasant personality became paramount. (2.) Janet's Marcelline, the classic patient whom he kept alive by inducing her second personality through hypnosis, was thirteen when brought to him for treatment. (18.) Miss Beauchamp, whose renown has spread far and wide, first came to Dr. Prince at the age of twenty-three, but her pathological manifestations began several years earlier. (25.)

These examples might be indefinitely multiplied, but since the problem of dual or multiple personality has received more popular attention than many other phenomena of abnormal psychology, it is unnecessary to go into details of these cases, although a general summarization 
of the eharacteristics which they possess in common may be of some interest. In the first place, as Sidis and Goodhart remark, the multiple personality is essentially an extreme form of the dissociation process which plays so important a rôle in the Freudian conception of the neuroses, only in this case it is an entire phase of the personality which becomes uncenscious. There can be two such separations, or an indefinite number; the essential point is that they oscillate between the realms of consciouness and unconsciousness, and take turns in becoming the conscious and dominant personality. (2\%) Usually, one of these personalities is more vital than the others, and can remember all that is said and done in the other states, while the less energetic individualities are cognizant only of their own existence.

Dr. Prince's case is typical of the temperamental diathesis which is favorable for the development of the multiple personality; he pictures Miss Beauchamp as exceedingly sensitive and suggestible in her nervous constitution, and emphasizes the habit of day-dreaming and flight from the unpleasant which she had es 
tablished as a refuge from the disagreeable surroundings of her childhood. (25.) Thus it becomes evident that the dissociation of personality is only the exaggeration of the normal tendencies of adolescence, with its everchanging moods, and its active imagination. The crux of the matter is the pathological instability of the nervous system which allows these moods to become completely separated from one another, and the over-development of the day-dreaming tendency as a means of escape from the realities of a painful environment, so that dream and actual event become indistinguishable.

Even more entirely the result of daydreaming than the development of a multiple personality is the pathological lying of hysterical girls which has been studied by Richard (26), Delbrück ( $r)$, Pick (23), Healy (17) and others. Richards says the lies are a mixture of delusions and deliberate falsehood; Pick tells of an eighteen-year-old girl whose lies were wholly descriptive of illusory experiences, and of a second case where the falsehoods were obviously insincere, although the result of am- 
bivalent desire for and fear of the erotic life; Delbrück gives a wide collection of cases in which delusion and deliberate falsehood are not to be distinguished one from the other, finding his material, as Healey does, largely among the delinquent classes.

Pres. Hall comments upon the psychopathic tendency to lie in the following words, which may well serve as a summarization of the whole problem :

"These often thwarted and abortive lives show, I think, a propensity to attract attention and be of importance, which is abnormal only in its degree and is morbidly and precociously developed. Some of these cases represent the revolt of natures handicapped by heredity and cramped in a narrow sphere... Some of the cases are intoxicated with the lust to broaden their experience, be and do things that they have heard others were and did, or to make possibilities actual. Moreover there is a strange tingling inebriation with the sense of being alive, that flagrant falsehood better than anything else excites in some natures. Precisely what they are not, they assume; what they cannot achieve, they do; wishes real and riot toward realization. They become drunk and debauched with lies as many have recourse to strong drink to escape the stress and strain of real life when 
it is hard, poor, and mean, for this is the chief motive that drives many to drink. . . .

"It is this point of view which reveals best of all cures and preventives of lying, viz., to enrich and enlarge actual life, to fill out experiences, so as to narrow the chasm between fact and fiction. The more physical development which tends to establish a close bond between knowing and doing, the more varied and interesting and absorbing the daily life, the more the best and strongest feelings are stirred and given vent; the more the youthful soul palpitates with the joy of existenee and accomplishment, the more zestful is the knowledge acquired and the less the temptation to every form of lying. Conversely, where life is made dull and strained by the environment or tense by disease or defect, so that the sonl is habitually hungry, there we have temptation to many ways of eseape, from runaways to falsehood. . . Without knowing it, these hysterical girls feel disinherited and robbed of their birthright. Their bourgeoning woman's instinct to be the center of interest and admiration bursts all bonds, and they speak and even act out what with others would be only secret reverie. Thus they can not only be appreciated but marveled at, ean almost become priestesses, pythonesses, mænads, and set their mates, neighbors, or even great savants agog and agape while they have their fling at life, rcckless of the eonsequences. Thus they can be of consequence, respected, observed, envied, perhaps even studied. So they defy their fate and wreak their little souls upon expression with abandon and 
have their supreme satisfaetion for a day, impelled to do so by blind instinct whieh their intellect is too undeveloped to restrain. And all this because their actual life is so dull and empty." (14: pp. 362-363.)

One other form of the hysterical trait is the abnormal degree which is sometimes attained by the adolescent tendency to conversion of the libido into religions worship., Psychoanalytic studies hare shown the strange mixture of holiness and eroticism twhich the image of Jesus or even of God himself, inspires in patients suffering from religious mania; while Pfister, in his analysis of the num, Margareta Ebner, has shown the mingling of the eestasies of sexuality and mysticism, as appearing in a highly symbolic form. (:2.)

In literature, Gerhart Hauptmann's Hannele furnishes an exquisite illustration of the tendency of the overwrought girl to convert her awakening love life into the chamnels of religious worship. (12.)

The daughter of a village drunkard, who beats and starves her mercilessly, Hannele's mind and body break down together. She calls indiscriminately upon Christ and her beloved teacher, Jesus-Gottwald, whom 
she identifies with the Saviour; and dying, is dressed in bridal robes, happy in the faith that she is taking her marriage vows instead of her death-bed consecration. Whether she dies from her fatler's blows, or from her plunge into the icy lake, whence she heard Jesus-Gottwald's holy voice calling to her, does not matter; the essential point is the unification of her earthly and spiritual love. The Frcudian formulas may well be utilized to explain Hannele's fantasies. The repressed love for her schoolmaster reinforces her heavenly adoration; the sense of sin connected with her sternly checked love for Gottwald, who is mar. ried, comes out in her delirium in the conviction that she has committed the unforgivable sin. Yet in the end she is at peace in the grasp of death, for has she not the magic cowslip flower which is the key to Heaven, and is she not at last the bride of her beloved Jesus-Gottwald?

Baring-Gould, in his Lives of the Saints, gives nearly two hundred and fifty cases in which adolescent girls are carried away by religious fervor, and although some of his stories are purely legendary, many authentic biographies are included. Perhaps one of the most interesting of these mediæval saints was Saint Theresa, whose life is typical of the whole class of religious fanatics described by Baring-Gould. (4: V. 10.) 
Saint Theresa lived in the early part of the sixteenth century, and was the child of noble and very virtuous parents, who brought their children up in accordance with the strictest teachings of the church. Her mother is described as being very delicate, and afflicted with numcrous infirmities, and it would appear that Theresa inherited from her a distinctly neuropathic temperament. With one of her brothers, who was most dearly loved by her, Theresa read the lives of the saints, and the two children planned to live together, hermit fashion, in emulation of these tales, or even to die the glorious death of martyrs. To the psychoanalyst, this suggests a precocious linking together of the erotic and religious elements of Saint Theresa's nature, in those tender years before the libido had begun to seek an adult goal, outside the family circle.

At twelve, Theresa lost her mother, and lacking her careful guidance, began reading a series of books which were well calculated to awaken her innocent mind to very definite and none too subtly expressed details of the sexual life, a knowledge which was confirmed by her own experiences, when, at the age of fourteen, she and a girl friend entered into all sorts of questionable intrigues with their male friends. As a result of her flirtations, her father placed her in a convent, where the training of her early youth was vividly recalled to her mind, so that she began to repent of her worldly ways, and to fear that she had offended God beyond all redemption. For a year and a half the struggle with her naturally strong erotic 
nature, whieh had been exaggerated by her experienee, continued; then she became ill, and was removed from the convent to her own home. During her illness, she suffered from the typical hysterical symptoms,-im. aginary pains, fainting fits, attacks of fever, etc., etc., -but by the time she was eighteen, she had determined, in spite of her ill health, to become a nun, and devote her life to God's service.

From her entrance into the convent, her life became a constant effort to satisfy her erotic cravings through means which were permissible under the guise of religious fervor. She tells of one confessor after another who became the recipients of her lavish affection, and whom she always desired to incite to greater service of God, since only in God could she hope to possess the affections which her vows forbade her to receive openly. "Though $I$ have him already in reality, yet that will not content me unless $I$ possess him altogether," she reports herself as saying about one of these confessors, in the course of her prayers, and to the analyst, there could be no clearer avowal of the erotic motif underlying her zeal for the souls of these men who roused in her a fanatic love.

The final stage in the eonversion of her libido was that in which she began to have the typical visions and eestasies of the religious mystie. In the midst of her temptations, the devil appeared to her in many guises, and she, all unwitting that this was but a projection of the sexual emotions which she would no longer admit formed a part of her makeup, was wont to call for holy water to exoreise the evil spirit. 
Conforming beautifully to the Freudian rubries, was one vision in which she says that "a seraph stabbed at her with a dart whose point burned with fire, and the barbed end entered her breast, eaught her bowels and pulled them out as the seraph drew away."

The erotic symbolism of such hallucinations is unmistakable, partieularly when she continues her account of the experienee thus: "The pain was so intense that it foreed deep groans from me; but the sweetness which this extreme pain eaused in me was so exeessive that there was no desiring to be free from it."

Little by little the visions grew to be more and more spiritual, and the religious replaced the erotie element more and more eompletely, or rather the disguises which her impulses assumed beeame better perfected, so that she grew to be revered as an excessively holy woman. Yet the sense of $\sin$ which had always oppressed her in her first passions for her confessors never wholly left her, even in the most ecstatic of her experiences. Thus she spent her life seeking to atone for her lustful impulses by mortifying the sinful flesh by all the penances known to the strietest aseeties of the past, at the same time revelling in ecstatic communieations with her "heavenly bridegroom," and dying firm in the belief that she was eonfirming her marriage to her God.

The anxiety nourosis, which is le's characteristic of the adolescent period, is closely allied to hysteria in its etiology, but the sexual emo- 
tion is converted to fear and anxiety, the general state of Angst into which the eroticism passes over, in accordance with the principles laid down by Cannon (as quoted in Chapter II), seizing upon almost any specific object on which to focus its energy. Dementia præcox, on the other hand, is characterized by an introversion of the libido, which, meeting with resistances which prevent its finding an objective fixation, is turned inward, and becomes transformed into fear, or, in its later stages, into auto-eroticism. (20.)

Thus, the clinical symptoms of D. P., the sinking into a state of lethargy and stupidity, are due to regeneration of function, rather than of structure, the vital energy becoming so wholly introverted that there remains no ability to focus the interest and attention on any object of the external work. This view is well brought out in the following analysis, in which Lucile Dooley shows the successive stages of libido regression which finally culminate in this form of insanity. (8.)

In October, 1916, there was brought to the hospital a young girl of eighteen, who exhibited all the symp- 
toms of manic-depressive insanity, with its alternations of stages of excitement and melancholy. Later, she showed all the symptoms of hysteria, and finally sank into an infantile and passive state which could only be classified as dementia pracox. The past history of this girl had been one of disappointments, both personally and socially. A father complex impelled her to try to identify herself with her mother, so that at twelve she had been possessed with an abnormal passion for her doll, and with an intense affection for the children of her neighborhood.

This CEdipus complex was complicated by a pathological tendency to eling to the shelter of her mother's care, to remain her baby, a tendency which was a direct result of a feeling of inferiority which made her feel unable to face the social situation unaided. The feeling of inferiority, which was biological in origin, as always, was intensified at the age of thirtecn, when for the first time she learned a little of what it meant to be a woman. To the feeling of rebellion at her lot was added the feeling that she was abnormal, since the expected menstruation did not occur until three years later when she was sixteen. The popularity of her younger sister increased her feeling of inferiority, but she compensated for her sexual failings by leading her class in all her studies, although secretly resolved to be a woman fully and completely, if ever maturity should be vouchsafed to her. The feeling that she was a helpless victim of fate was now increased by the innocent contraction of a venereal disease, and at last she broke down, and was taken 
to the hospital in a state of mania the very fall she had expected to enter college.

The first regression of the libido was to a stage in which she evinced the hysterical desire of attention, and was expressed in tearing up the blankets on her bed to obtain the briglit eolored strips for ribbons; by the invention of all sorts of symbolie games which expressed the repressed fixation on the father; in dramatic representations and the creation of poems which embodied her erotic fantasies. Then she sank to an infantile level, where she loved to be commanded, dramatized ITugo's The Order's of the King, and faneied herself a prisoner in the Kaiser's palace. In this stage her father was no longer the ideal of her girlish heart, but the one who must be obeyed, and as such was variously pictured as the Kaiser, king, Harry Thaw, villain in the play, etc. Narcissitic impulses also developed, and finally, sinking below the infantile to the pre-natal level of dementia præcox in its lowest stages, she became not only auto-erotic, but a "smearer."

The interesting part of this ease, however, is the complete eure which the analysis effected. As the girl began to recover, she retraced all the steps by which she had sunken to this lowest level. The first indication that she was coming up from the pre-natal plane was a desire to serub the floor and walls of her room, which she had made utterly filthy in her archaic state. Then came a strange case of infantile foot-fetishism, and finally the adolescent level of the hysteria was reached, which elung a long time with 
its color symbols and other delusions. Finally, she had retained of her insanity only one symptom,--a recurrent dream, in which she was combing the snarls out of her hair. Whenever a lock was pulled out, it turned into a snake, which she burned. When the last lock was pulled out and burned, the dream did not return again, and as her eomplexes,- - the abnormal love of her father and hatred of her sister,- -had been smoothed out earlier in the treatment, she became a normal adoleseent, with no tendeney to lapse into the old neurotieism.

In addition to these distinetly psychopathic traits of adolescence, there are all sorts of phenomena which border on the abnormal, although they are not so marked as to interfere with the intellectual and social activities of the individual. Very often the adolescent girl is obsessed by some bizarre fancy, which might well slip over into the category of the neurotic conflict, but for sheer good fortune, and the native tendency of the mind to strive for healthy functioning. "The naturally secretive. nature of the adolescent girl prevents her revealing these strange fantasies, except to a few sworn comrades, no wiser than herself, for she 
fears incurring ridicule from her adult friends and relatives.

Two cases typical of these borderline phenomena recur to my memory from the experience of college days.

I. Miss Black was a delicate, rather nervous girl, with the marked literary talent which is often characteristic of sensitive, dreamy natures. She had just become engaged to a young man very much her inferior mentally, but whom she professed to love wholeheartedly. Very soon, however, she began to develop a strange hallucination, in which a skull displaced the features of her lover whenever she tried to image his face, or gazed at his picture. To the psychoanalyst, this fact, in conjunction with certain details of her history which I will not take time to relate here, would indicate an erotic conflict, which might well lead to a neurosis if long continued.

II. Miss White was a rather moody personality, at some times rather gay and fond of masculine attention, but at others very reserved and quiet and absorbed in her studies. The striking thing about her case was the variation in handwriting which she displayed during these periods, a difference so marked that it attracted the attention of her psychology teacher.

If, as Victor Mercante asserts in his recent book, "La crisis de la pubertad" (21), the handwriting is simply a motor indication of the adolescent frame of 
mind, it would seem that two separate personalities were struggling for survival within the girl's soul. This view was confirmed by Dr. Prince, who declared the specimens of writing submitted to him could only indicate the incipient stages of a dissociated personality.

If his diagnosis was correct, the dragging of the matter thus to consciousness must have been an excellent therapeutic measure, for the quieter handwriting gradually came to replace the bolder script entirely.

One of the commonest perversions of the libido among adolescent girls is the fixation of the affections on members of the same sex, and absolute indifference or even aversion to male companionship. ${ }^{*}$ In extremely pathological cases, this tendency may involve gross physical manifestations, and be distinctly homosexual in nature; but generally it is a very high and noble sentiment, and is to be censored only as it prevents an ultimate trans-

* At the International Conference of Medical Women in New York, Sept. 15-Oct. 25, 1919, Dr. Constance Long (of England), Dr. Eleanor Bertine (of New York), and other leading medical women, emphasized the increasing rôle which homosexuality is coming to play in the life of the nodern girl. According to their view, it is the failure to transfer the libido from a love object of the same sex to one of the opposite sex, which is responsible in part for the increasing num. ber of women celibates and divorcées. 
ference of the love-life to its more natural object.

Ambivalent forms of the CEdipus complex, in which the mother has been idealized and the father disliked or feared, is one factor which helps in this fixation of the libido on other girls or older women; a distaste for the sexual relationship caused by the teaching that it is degrading or the impression that it involves suffering and pain is a second motive, while finally, the domination by a power complex may incite a dislike of yielding to the domineering influence of the passion of the male, when a like degree of affection can be obtained through the worship of other girls, whose attitude at the same time gratifies the longing for power.

Moreover, there are certain conditions in the social life of our times which tend to favor the development of any homosexual trend in the adolescent girl. There is a growing antagionism to the masculine double moral standard and general attitude toward women on the part of girls who have accepted the feminist philosophy which makes them unwilling to venture into matrimony with the average man whom they 
meet. The newly aroused ambition of woman for a life work of her own other than wifehood and motherhood is another powerful force impelling her to hesitate before entering upon a relationship which will in all probability thwart such desires. ${ }^{*}$ With the denial of an outlet for her sexual impulses in marriage, however, comes the tendency to substitute uneonventional heterosexual relationships or to find a love object in members of the same sex. The latter proceeding becomes all the easier with the existence of a comparatively large number of professional women, who approximate to some extent the traditional male characteristics of aggression and enterprise,

Clemence Dane's Regiment of Women (6) is an absorbing study of the development of this characteristic in the three principal characters of the book,Clare Hartley, Louise Denny, and Alwynne Durand. The scene is an English school for girls, where the "crush" is the accepted order of things, and is allowed to reach its climax in poor little Louise Denny, the motherless child who fixes her affections on her beloved teacher, Miss Hartley, and whose heart is broken when she fancies she has fallen out of the

* See ease of Miss Y, Chapter III. 
good graees of her adored one. Louise is a precocious child, just entering the adoleseent period; a dreamy, sensitive nature, misunderstood by her father and stepmother, so that she has sought refuge in a wor? ${ }^{-}$ of fancy in which she is visited by the dead mothe whom she believes is reinearnated in Clare Hartley.

Clare, the perfeet Adlerian type, is amused by her power over Louise, and pets her until she has made the lonely child her slave. Being utterly selfish, however, she soon tires of her plaything, and when Louise irritates her, does not hesitate to make her displeasure felt. Perhaps she is all the more tempted to show her moods beeause she loves to see others writhe under her scorn, and to feel the intoxicating sense of power that acerues from the knowledge that a single word ean make or mar the happiness of her followers.

Miss Durand, the younger teacher, is also a satellite of Clare's, and as worshipful of her heroine as is little Louise; but hers is a less abnormal affection, and when the conflict comes, she sees the unworthiness of her idol, and is able to make the normal transference of her love-life to Roger Lumsden. The climax of the book eenters around the tragie death of Louise, who under the torture of being made to feel that she has wholly forfeited Clare's affection, finds life too hard to face, and seeks the mother of her visions by the path of suieide.

It is hard to say which is the more instruetive study, from the psyehological point of view, Clare, with her insatiable thirst for the worship of other's, which she repays with a strange affection wholly pe- 
culiar to her own nature, or Louise with her dreams that border on delusions, her oversensitive reactions, and her overstrained nervous system, which she has ex bausted in the effort to attain to all that her goddecs, expects of her, and in rain emotional outbursts as one thing after another accumulates to add to her childish sorrows.

A more usual case of this spiritualized homosexuality came under my observation in a college friend, who had a positive aversion to men, so that she would not even accept invitations to dances or other social functions, preferring to remain at home when a male escort was the only alternative. She was in the habit of developing violent crushes on other girls, and during the most ardent part of the friendships would be consumed with jealousy of their girl friends, although she never objected to their receiving attention from men. Doubtless the basis of her aversion to men was the utter ignorance she had of all sexual matters, the repression of her erotic nature being the most complete I have ever seen in a girl who shows every evidence of possessing a potential capacity for passion. She is now twenty-two years old, however, and this passion is still 
latent, while she shows no curiosity in regard to the sexual iife. She admits that at this one point her mother has failed her, and says that as a result of the vagueness of her knowledge, she is very nervous when with men, and fears to have anything to do with them.

Although the formal inception of these and similar neurotic afflictions takes place at pubescence, their roots extend far back into the childhood of the girl, and in many instances the knowledge of a few psychological principles, and the exercise of a small degree of foresight on the part of parents and teachers, would serve to prevent them entirely. The tendencies at the bottom of the neuroses are in themselves normal and wholesome, it is only the exaggerated degree which they assume that makes them pathological in nature. Every adolescent girl possesses the same capacities for transformation of the sexual instinct into substantive channels, a power limited only by the degree of eroticism which is inherent in her organic structure and function. It depends only upon her nervous equipment, and nost of all upon the long series of external stimuli to which she 
has been subjected as to what form these vicaria shall take, and whether the conversion shall be to a higher or lower level. The environmental factors which shape her reaction have been more or less clearly hinted at-the influence of the family situation and the method of acquiring sexual knowledge being most important.

The Freudian analyses have shown the immense significance attached to the father in shaping the girl's life; it is equally injurious for her to love him too well, or to look upon him with distrust and hatred, because either attitude prevents a happy transference of her love-life to eligible persons of the opposite sex. Again, the impulse to return to the protected state of infancy, when there was utter rest in the maternal womb, which Ferenczi has emphasized, (10), reinforces the famous Freudian flight from reality, and encourages introversion of the libido, with its subjective element, and its creation of a dream-world which may come to replace the outer world of actual events. Hence Jung's ambivalent conception, which notes also the rebellion of the girl against restraint as she strives to free herself from this childish cling- 
ing to the maternal protection, in order to meet the new world which attracts, even while it terrifies. (20.)

In so far as reality proves pleasurable, there will, of course be no mental conflict, or attempt to take refuge in day-dreams. Normally, reality should give access to a fuller, richer life, in which the imagination is utilized constructively in the higher synthesis of Baldwin's conception (3), to formulate ideals for the future, and in work and creative endeavor, not in the weaving of fantasies which are a satisfaction per se, and paralyze the active nature of the organism. The childhood which creates in the girl a mental state which is so incompatible with the facts of everyday life that her tortured mind refuses to make the broader social adjustment from the home circle which becomes necessary at adolescence, or which has so over-sheltered her from natural results of her reactions that she has never been prepared to undergo the pain which is followed by a more lasting happiness, is the ultimate cause of the adolescent neurosis, and the source of the psychic resistance which makes the higher sublimation next to impossible. 
From this point of view, the duty of parent and teacher alike becomes clear. To the former is given the task of providing for the child and young girl a normal home life, in which there is neither too much nor too little affection, and in which the child is guarded from pathological situations, but not overprotected from the automatic results of breaking natural and social laws. To the teacher falls the more difficult work of inspiring that correct use of the ability to dream which forms the basis of the interests, the idealizations, and the sublimations which prove invaluable as the means of transmuting the great fund of organic energy into those higher erethic calentures which make for the happiness of the individual and the welfare of the race.

A quite different solution of the difficulties of the adolescent girl is that proposed by certain extremists among the psychoanalysts. Ignoring the fact that the sexual energy of humanity is anything more than a simple physical reaction, these men gravely urge that the adolescent girl who finds the problem of controlling and sublimating her impulses too. 
arduous, be allowed full satisfaction of the sexual instinct on the biological level. The disastrous results of a general acceptance of this advice are only too plain. Aside from the mental conflict induced by a throwing aside of social conventions, which involves a repression of the gregarious instinct and a violation of ingrained ideals of conduct, the very nature of the female organism, in its biological and psychological structure, prohibits the success of this solution.

The sexual impulse of woman is not the simple momentary desire of the male, but a highly ambivalent emotion, in which fear is intimately mingled with desire, because a long evolutionary history has made the sexual act fraught with dire and painful consequences for the female, so that her psyche reverberates with hidden phyletic memories associated with her long travail as mate and mother. The whole weight of social training which the young girl ordinarily receives only serves to emphasize this reaction, for however she learns the details of the sexual life, it appears to her as a thing - to inspire terror as well as fascination. This element of aversion is induced alike by the 
perverse manner in which most mothers impart information, picturing sexuality as an emotion utterly incompatible with native refinement of character; or by gleaning the knowledge from surreptitious reading matter, since the books upon the subject are for the most part medical treatises which mention the painful features of the first coitus and loss of virginity, and describe all the pathological and diseased aspects of a function which is normally as simply and naturally carried out as most other instinctive activities.

The ideal method of sexual enlightenment would be the impersonal teaching of biological facts to the child in the course of its school curriculum, so that the secret of reproduction would be understood by the girl at an age when the passionate element would not confuse her judgment, and the great function of motherhood would come to stand out as the supremely important event of the process. Even then, the problem would only be lessened to the extent that this natural and healthful imparting of knowledge would decrease the adolescent conflict by removing the complicating factors of 
morbid curiosity, and rebellion against facts hitherto unsuspected and unknown. The necessity of a probation period, in which the awakering sexual energy is controlled and turned into higher channels that become the foundation for the fullest and richest living, is not removed, and it is the destruction of this supreme ability to experience the noblest emotions at which the lowering of the standards of sexual morality aims.

In the final analysis, then, the adolescent conflict is the crisis which makes or mars the future of the individual, not only in the matter of personal welfare, but also from the standpoint of social efficiency. It is the transmutation of the sexual energy into the righteous anger of the social reformer that makes the world continually a better place to dwell in; it is the thrill of beauty which is analogous to the ecstasy of the sex experience that has given us a civilization in which music, literature and art are the highest values; it is the conversion of the love of the mate into the love of truth and knowledge, the joy of creation on the intellectual as well as the biological plane, that 
has given us the great laws and principles of scientific discoveries; and it is the final spiritualization of the sexual impulse which has fashioned for us our great religious systems, our inspiring philosophies, and the high ideals which serve to turn the emotional energy to the service of those intellectual faculties with which it might otherwise spend its powers in hopeless conflict.

If we regard the problem of the adolescent girl from this larger viewpoint, we see that it is not merely a matter of preventing her loss of sane and healthy balance with which we are called upon to deal, but a question of a make or break process, in which it is as deep a tragedy for her to fall short of the ultimate goal of the maximum utilization of her energy on both the biological and social levels, as it is for her to sink into the depths of the neurosis, a fate worse only in degree, not in kind.

\section{BIBLIOGRAPHY FOR CHAPTER V}

1. Adler, Alfred. The Neurotic Constitution. 456 pp. Moffat, Yard \& Co. N. Y., 1917.

2. Azam, E. Double Conscience, Etat Actuel de Félida X. Impr. de Chaix. Paris, 1883. 
3. Baldwin, James Mark. Genetic Theory of Reality. 355 pp. Putnam's Sons. N. Y., 1915.

4. Baring-Gould, S. Lives of the Saints. 12 vols. Vol. 10. Hodges. London, 1887.

5. Barrett. Proceedings of the Society for Psychical Research. V. 11.

6. Dane, Clemence. A Regiment of Women. $345 \mathrm{pp}$. Heinemann. London, 1917.

7. Delbrück, A. Die Patlologische Lüge und Die Psyehische Abnormen Schwindler. 131 pp. Enke. Stuttgart, 1891.

8. Dooley, Lucile. Analysis of a Case of Manic-Depressive Psychosis Showing Well-marked Regressive Stages. Psvehoanalytic Rev. V. 1. Pp. 1-46. Nerv. \& Ment. Dis. Pub. Co. Washington, D. C., Jan., 1918.

9. Federn, Paul. Some General Remarks on the Principles of Pain-Pleasure and of Reality. Pp. 1-12. Psychoanalytic Rev. II. N. Y., 1915.

10. Ferenczi, Saudor. Contributions to Psychoanalysis. 288 pp. Badger. Boston, 1916.

11. Freud, Sigmund. Selected Papers on Hysteria. 215 pp. Jour. Nerv. \& Ment. Disease Pub. Co. N. Y., 1912.

12. Hauptmann, Gerhart. Hannele: A Dream Poem. 92 pp. Heinemann. London, 1907.

13. Hall, G. Stanley. A Medium in the Bud. Pp. 144159. American Jour. Psychol. XXIX, 2, April, 1918.

14. - Edueational Problems. 2 Vols. Appleton. N. Y., 1911.

15. Healy, Wm. The Individual Delinquent. $830 \mathrm{pp}$. Little, Brown \& Co. Boston, 1915. 
16. Healy, Wm. Case Studies of Mentally and Morally Abnormal Types. 77 pp. Harvard Univ. Press. Cambridge, 1912.

17. —_ Patbological Lying. 286 pp. Little, Brown \& Co. Boston, 1915.

18. Janet, Pierre. The Major Symptoms of Hysteria. 345 pp. Macmillan. N. Y., 1913.

19. Jung, C. G. Psyehology of the Unconscious. (Wandelungen und Symbole der Libido.) Pp. 566. Moffat, Yard \& Co. N. Y., 1916.

20. Psycliology of Dementia Praecox. 153 pp. Jour. Nerv. \& Ment. Dis. Pub. Co. N. Y., 1909.

21. Mercante, Victor. La Crisis de la Pubertad. 437 pp. Cabaut y Cia. Buenos Aires, 1918.

22. Pfister, Oskar. The Hysteria and Mysticism of Margareta Ebner. Zentralblatt für Psychoanalyses. Pp. 468-486, 1911.

23. Pick, A. Ueber Patbologische Traumerei und Ihre Beziehungen zur Hysterie. Pp. 280-301. Jahrb. f. Psychiatrie u. Neurologie. V. 14, 1895-96.

24. Podmore, Frank. Modern Spiritualism; A History and a Criticism. Methuen. 2 vols. London, 1902.

25. Prince, Morton. The Dissociation of a Personality. 569 pp. Longmans, Green \& Co. N. Y., 1906.

26. Richard, P. A. M. Le Mensonge chez la Femme Hysterique. (Thése méd.) $66 \mathrm{pp}$. Y. Cadoret. Bordeaux, 1902.

27. Sidis and Goodhart. Multiple Personality. $462 \mathrm{pp}$. Appleton. N. Y., 1905. 


\section{CHAPTER VI}

\section{THE ADOLESCENT GIRL AND LOVE}

Love the center of girlish reveries; Scientific studies of love;

Composite sentiment, mere sexual passion, outgrowth of the sense of touch; Finck's conception of romantic love; Views of Carpenter and Mantegazza; Inadequacy of these seientifie formulæ; Philosophical theories of love; Empedocles, Judah Leo, Plato, Schopenhauer, View of Renooz; Metabolic basis of sex attraction; Weiniger's male and female plasm; Blair Bell's sex complex; Pearson's statistical studies; Psychoanalytic view of compensation throngh love; New ideal of love and the adolescent girl.

There is probably no theme which is so constantly the center of the young girl's reveries as that of love and marriage. With a strange intermingling of shyness and fascination, her thoughts turn irresistibly to this all-absorbing subject. She weaves wonderful dreams of the fairy prince who shall one day come gloriously into her life, and teach her the whole, sweet meaning of the mysterious word, which has 
come to be the alpha and omega of her existence. But, in spite of her visions, doubts arise. How will she recognize love when it comes? How know the true from the false? For it cannot but be borne in upon her observing mind, uncritical though it may be, that sad mistakes are sometimes made in the name of love, and she must not add to these.

In this dilemna, she knows not where to turn. No text-book offers its timely aid; if she seeks advice from those older and more experienced than herself, she gets little help beyond the comforting assurance that her problem will work itself out aright in due time and that her anxiety is needless. Literature, to be sure, deals almost exclusively with the topic which is nearest to her interests, but it pictures love so variously that her eager readings leave her with an impression so hopelessly confused that she may well despair of the possibility of attaining any definite knowledge in this line.

For long ages, it was the poet, alone, who saw the all-impelling force of love as a universal human motive, but gradually the scientists, too, began to recognize its position as an 
all-important factor in the affairs of mankind. and attempted to subject it to a cold and impartial analysis. Let us briefly review their conclusions, in order to determine whether they can be of any pragmatic value to the adolescent girl in her anxious debates.

Ribot, in his Psychology of the Emotions, was the first to advance the view that the love of man is not the simple physical impulse to reproduction, but is a composite of various instincts, in which sympathy, tenderness, and the parental feelings blend, with the cruder sexual emotions to produce a perfect whole.

(19.) Henry Drummond, on the other hand, while also pointing out the complex nature of human love, makes the maternal instinct its basis, rather than the sexual impulse. ( $7:$ p. 224.) Sutherland (23) and Kropotkin (14), emphasizing the selective value of mutual aid, think sympathy is the essential component which differentiates love from pure sexuality; while MacDougall, the most modern representative of this trend of thought, agrees with Ribot that love is sexuality glorified by the addition of sympathy and the tenderness first developed in 
the care of offspring. Miss Smith, too, from her study of adolescent love, was led to believe that the altruistic emotions based on the gregarious and parental instincts, played an important rôle. (22.)

A diametrically opposed theory is that of the French psychologist, Roux, who makes the love of man for his mate a wholly sensual matter, based on the sexual needs of the organism, reinforced by the desire for voluptuous pleasure. For this view, the sensations from the reproductive organs are the source of the undirected sexual impulse, but the specific focusing of the erotic nature is determined by olfactory, visual, auditory, and even tactual sensations. Thus the perfume of the hair, personal beauty, the voice, and manner of kissing become decisive factors in the choice of a mate. (20.) Bloch, in his elaborate volume entitled The Sexual Life of Our Time, is inclined to a similar conception of the love-life of mankind, but adds that these various voluptuous sensations become associated with more spiritualized thoughts and feelings, so that 
through the body the personality of the loved one becomes the object of worship. (4.)

Alexander Bain makes love as purely a matter of sensation as Roux or Bloch, but it is the tactual sense which is most significant in his scheme, for he makes sheer physical contact-the pleasure of the "animal embrace"the root of sexuality as of sympathy, gregariousness, maternal love, and all the altruistic tendencies. (2.) Walter Gallichan also thinks the sense of touch cammot be overestimated as a factor of the erotic life. $\mathrm{He}$ quotes Gowers to the effect that the sexual act is a skin reflex, and subscribes whole-heartedly to this statement. Indeed, Gallichan declares that this is the one criterion by which the inexperienced maiden may recognize her real mate, since her whole being must thrill at the least contact with the man who possesses a true attraction for her. Through his caresses, which appeal thus ardently to her tactile sense, she unconsciously feels the manhood and strength of personality and physique that serves the race. (11.)

For Henry Finck, not the sexual impulse, but 
the appeals through the other senses, are the criterion by which we may distinguish love from lust. We may compare love to a strain of music, in which sex is the fundamental, and the overtones are all those things which go to determine individual preference. (9.) Primitive love was a mere animal impulse; not until the age of romantic love, which is distinctly modern, did a truly noble and unselfish emotion for members of the opposite sex come into existence. (8.) This type of affection is based not only upon the inclusion of the tender, protective elements of sympathy and the parental feelings in the attitude toward the other sex, but is dependent upon an xsthetic appreciation of the beauty of the human face and form per se. The coyness of the female, and delight in her beauty, have caused man to develop a devotion for woman in which the brutal element of sex passion is toned down, and admiration and reverence are the uppermost characteristics of his amorous feelings.

Edward Carpenter makes the desire for union the central point of love, and characterises the sexual act as symbolic of the deeper 
union of the soul which exists between every truly loving couple. Woman experiences this genuine emotion more often than man, for seldom does she divorce the sexual passion from her other sentiments, while in man it is often a quite separate part of his nature.

Mantegazza, in his Book of Love, takes a similar stand, emphasizing the fact that the love union is a union of the soul as well as of the sense; and asserting that woman is the high priestess of love, while man often rests content with mere physical emotions of the sexual instinct. He adds that the love which different individuals are capable of feeling is as widely unlike as their temperaments, and attempts to classify the various types, i.e. tender, contemplative, sensual, ferocious, proud, etc. (15.)

Conflicting as the statements thus briefly epitomized may seem, each has its elements of truth, and must be given due consideration by the adolescent girl in her attempts to solve the problem of her own personal happiness. Yet, after all, they are too narrow, too analytical, to prove of lasting satisfaction to her active mentality; what she seeks is a broader view, a 
more synthetic statement, some general principle to which she can cling as a guide among these changing factors, as first one, then another looms up larger, or nearer at hand, and threatens to obliterate the others. But the scientist has no more to offer, for it is his business to analyze; we must, therefore, have recourse to philosophy, which in the very nature of things should be synthetic in character, and possess a widely sweeping scope.

When we turn to the history of philosophy for guidance, we find little that is even remotely applicable to the problem of love between the sexes. Empedocles, for example, made Love and Hate the ruling forces of the universe, picturing love as an attractive force which tended to draw all things together into a blessed sphere, while hate, the repulsive power, exerted all its energy in an attempt to separate the elements and produce a state of chaos. Thus abstractly spoke most of the Greek philosophers, for as a whole they dealt with universal processes, not with human life and activities. Judah Leo's conception became more concrete, for although he defined love as cosmic attrac- 
tion, he distinguished natural love, the attraction between inanimate objects, from the sensible love existing among animals, and the rational love peculiar to men, angels and God.

Plato, in one of his myths, wove a fanciful suggestion of the cause of sex attraction, which has been so paralleled in later times that it should be mentioned in this connection. According to Plato's idea, man and woman were originally united in one person. In his overweening lust for power, this primeval human type attempted to usurp the kingdom of the gods, and was cut in two by the great God Zeus, in order that his strength might be diminished by half. Then the two halves of each person went seeking each other, and when they chanced to meet, they fell into each other's arms, and were like to die of hunger, so that Zeus was forced to create sex to save mankind from extinction.

It is not so long a leap from this myth of Plato's to Schopenhauer's belief that complementary types fall in love with each other, every person recogmizing and worshipping in 
his mate the qualities which are lacking in himself.

"The growing inclination of the two lovers is really already the will to live of the new individual which they can and desire to produce; even in the meeting of their longing glances its new life breaks out, and announces itself as a future individuality harmoniously and well composed. They feel the longing for an actual mind and fusing together into a single being; this longing receives its fulfillment in the child which is produced by them, as that in which the qualities transmitted by them both live on, fused and united in one being." (21: p. 342.) The lovers are helpless in the grasp of the emotion because it is the will of the race expressing itself through them. It is for the purpose of producing a child which shall conform to the generic type of perfection that nature has ordained the powerful attraction of opposites for one another. If the lovers expect to find happiness in their union they deceive themselves, for in its very character it precludes any sympathetic and harmonious basis for marital life. The momentary illusion of happiness is but the 
glamour which nature casts over the young people in order to insure the welfare of the race.

Later writers seized upon the idea thus formulated by Plato and Schopenhauer, and attempted to work out on a more scientific basis the principle of compensation which these two philosophers had implied in their treatment of sexual attraction. Renooz, in his Psychologie Comparée de l'Homme et de la Femme, held to this attraction of opposites theory, and described man as a sensory apparatus, while woman was considered constructive and nutritive. But Renooz wandered into a maze of absurd detail in the presentation of his hypothesis, declaring man to be attracted by the blood of the woman, by her flesh, and repulsed by her nervous elements, while the woman's love for the man is simply a reversal of this process. That woman is essentially a creature of flesh and blood is sufficiently proven by the phenomena of menstruation and ovulation, he thinks, while the cerebro-spinal system of the male is more intimately connected with sex. After coitus the nervous system of woman becomes more predominant, while the fleshly element is exalted 
in man, so that they no longer attract each other, until the balance swings back and makes them at opposite poles again. (18.)

Following the lead of the biological theories of Geddes and Thompson $(10 ; 21 ; 24)$, there came a group of writers who explained the differences between the male and female organisms as a matter of metabolism. Drawing their analogy from the ovum and sperm cells, they looked upon the male as primarily catabolic, the female being essentially given over to anabolic activities. Thus sex attraction in humanity becomes merely a more complex form of the chemical affinity which governed the conjugation of the unicellular protozoans, and grows out of the attempt to preserve the metabolic balance of the individual and the species.

Weiniger advanced a wholly different explanation and postulated a male plasm (arrhenoplasm) and a female plasm (thelyplasm). He stated that every cell in the body is composed of plasm lying somewhere on the curve between these two extremes, although it never happens that there is borm an ideal man or woman in whom the plasm is wholly male or 
wholly female. It is the attempt to attain absolute masculinity and femininity which occasions love, the desire for union. Thus, the man who is $3 / 4$ male and $1 / 4$ female mates with the woman who is $3 / 4$ female and $1 / 4$ male, so that marriage produces a complete man and a complete woman. He is as pessimistic as Schopenhauer about the happiness of the union, however, and declares that the female plasm is so inferior that man only retains any love for woman by projecting upon her his own personality and entering upon a course of entire self-deception. (25.)

Blair Bell's experimental work was the final word in this long quest for the fundamental characteristic which was the distinguishing feature of sex, and resulted in placing the matter on a firm scientific foundation. Prof. Bell discovered that the ultimate basis of sexuality was the functioning of the whole system of ductless glands, and depended almost entirely upon the interaction of the internal secretions produced by the endocritic system, which includes not only the ovaries and testicles, but the adrenals, thyroids, thymus, etc. (3.) 
Since masculinity and femininity thus rest only in part upon the reproductive organs proper, it follows that Weiniger's coneeption of varying degrees of masculinity and femininity holds good, but whether this plays so exact a part in mating as he believed is an open question. Certainly, the statistical researches of Karl Pearson do not go to support this theory, for in so far as such crude physical traits as height, color of hair and eyes, ete., go, Pearson has been able to express his conclusions in the law "that like tends to mate with like." (1\%.)

On the other hand, the recent psychoanalytic studies, with their emphasis on the feelings of weakness and limitation which oppress the ego, suggest that all these philosophic and semiscientific theories which make love the union of opposites are merely an attempt to project a fundamental subjective tendency into the objective world. For it may well be that we love those whom we image as being the fortunate possessors of traits of personality that we would fain have exemplified in our own individual existence, and that in uniting ourselves with those whom we believe to be thus endowed, we 
are simply striving to satisfy the primeval - longing to feel ourselves a complete and perfect whole. Certain it is that such a longing for organic wholeness is one of the strongest of our innate tendencies, and who can doubt that we worship in others those qualities which we see inherent in our ego-ideals, but which are often sadly lacking in our everyday existence? If this be true, we can understand why our affection for the beloved seems so eminently rational, while we can perceive no adequate reason for its return.

$T$ Whether this theory, too, is more fancy or fact, it is no more optimistic than the views of Schopenhauer and Weiniger, for the mating of psychical opposites does not necessarily promise lasting happiness, while the danger of creating a false ideal and experiencing disillusioning disappointment is exceedingly great. Thus it appears that philosophical theories have little more application to the problem of the adolescent girl than did the more strictly scientific treatments, for although they give her a broad outlook and steadying perspective in 
her time of stress, yet they do not answer her greatest question:

"What is the ideal of love which I must set up for myself, and how can I achieve a mating that will endure in all the fineness of its spirit after the first ecstatic flush has died away, and saner living is once more the order of the day?",

This quest of the adolescent girl for an interpretation of love which shall be adequate to the needs of life, is but an expression of the growing unrest of the times in matters concerning the relationships between the sexes, and is an integral part of the mysterious force "which in the course of evolution has raised instinct into passion, passion into love, and which is now striving to raise love itself to an even greater love." (13:p. 46.)

The unhappiness of the modern marriage does not rest entirely upon the mistakes made by the two partners in estimating each other's sexual nature, as Havelock Ellis and other writers have insisted, for the present generation, in America, at least, is not apt to be reticent during the engagement period, and for the most part have learned to know and under- 
stand each other intimately within that time. It is rather in the fundamental philosophy of life, in the whole conception of the meaning of love in the cosmic process, that the great mistake is made, so that fires that once burned with an intense flame, flicker and flare out as physical passion is sated, and can only be rekindled at some new toreh.

Thus far, there have been two main tendencies apparent in the attempt to formulate a genuine philosophy of love;-one, a reaction to the centuries of asceticism which oppressed mankind, has emphasized the naturalness of the sexual instinct until man swung to the opposite extreme, and began to use it wholly for his own individual pleasure; the other, establishing itself upon firm scientific foundations, set up the eugenic ideal, and while admitting the healthiness of the instinctive life, demanded that it be used only for its legitimate purpose,-the good of the race. Since it is only too apparent that it is the eugenic conscience which is tending to influence the mores, and thus to become a vital part of the social life, it seems almost that we must revert to the old Schopenhauerian pessim- 
ism, and regard love not as a thing for personal enjoyment, but as an irresistible force which exists only in the interests of the species.

There is a deeper view, however, which, while it recognizes the ancient conflict between the individualistic and the racial tendencies, sees the underlying harmony which is within our grasp if we are only wise enough and patient enough to be worthy of its attaimment. For in the final analysis, it is only as we truly surrender our little lives to the fuller impulses of the whole universal process that we can attain happiness, and so it is that the love which exists for and in one person can never reach the heights of perfection accessible to the deeper affection which reaches out through the loved one to contact with the richer life of all humanity. It is not merely the merging of the love for one another into a common love for offspring that insures its fullness and continuity, for there are those to whom, for various reasons, the joy of parenthood must be denied. In order to be real and lasting, love must not stop at mere mutual pleasure; it must be creative, for it is by its very nature dynamic, a part 
of the great élan vital which is the ultimate source of all existence.

Therefore, as Ellen Key has said, "Love must give life; if not new living beings then new values; it must enrich the lovers themselves, and through them mankind.'" (13: p. 4\%.) "But the band which attaches it to humanity may be woven of several materials," Miss Key continues, "the gift to the race may express itself in various ways. In one case a great emotion may bring about a tragic fate which opens the eyes of humanity to the red abysses it contains within itself. Another time it may create a great happiness which sheds its radiance around the happy ones, illuminating all who come near them. In many cases, love translates itself into intellectual achievements, or useful social work; in most it results in two more perfect human beings, and new creatures, still more perfect than themselves."' (13: p. 48.)

At the same time that the individual gives up his will to the great racial forces which sweep through his soul, and lives in them and for them, it is possible for him to realize the highest personal joy in the very emotion which 
impels him to live for other beings than himself. For besides the primeval urge which draws man and woman together for the purpose of transmitting the vital energy in its biological continuity, there is another element which enters into human love--the desire to lose oneself in a larger life than that which is permitted by the narrow limitations of consciousness. It is the same desire which impelled the mystics of old to seek forgetfulness of self and escape from the narrowness of earthly existence through union with God, and which, denied this access to the peace that passeth all understanding, can achieve the same ecstatic state of perfect tranquillity only as the individual is able to feel himself entering into the inner life of another personality, until the two are fused into one perfect whole. Ellen Key has expressed this desire very simply and lucidly:

"The new love is still the natural attraction of man and woman to each other for the continuance of the race. . . But above this eternal nature of love, beyond this primeval cause of marriage, another longing has grown with increasing strength. This is not directed toward 
the continuance of the race. It has sprung from man's sense of loneliness within his race, a loneliness which is ever greater in proportion as his soul is exceptional. It is the pining for that human soul which is to release our own from this torment of solitude; a torment which was formerly allayed by repose in God, but which now seeks its rest with an equal, with a soul that has itself lain wakeful with eyelids heated from the same longing; a soul empowered by love to the miracle of redeeming our soul-as itself by ours is redeemed-from the sense of being a stranger upon the earth; a soul before whose warmth our own lets fall the covering that the world's coldness has imposed upon it, and shows its secrets and its glories without shame." (13:p. \%1.)

Yet it is not mere loneliness that thus impels us, but also that inner striving for perfection which would have us embody in our own being the perfect racial type, and which depresses us as we unconsciously feel how far short we fall of that ultimate goal of evolutionary perfection, a goal which may never be attained, but toward which the great stream of life is ever flowing. 
To-day, indeed, we are so far from that ultimate end and aim of life that the fusion of our single personality with one other can only temporarily quiet the unrest within our soul. Then it is that we must reach out through this little intimacy to enter into the larger life of humanity as a whole, for only as we conceive ourselves as a part of the entire organic existence of the species can we achieve the feeling of wholeness which brings lasting contentment.

In this very process, we are at the same time fulfilling two other purposes, for as it is through the medinm of the beloved person that we enter into the life of the race, so our love for that person becomes rich and full of meaning, while in so far as we feel ourselves an integral part of all humanity, we are impelled to work for its good, so that our love becomes creative and unselfish, in harmony with its original purpose. Thus, in the final synthesis, the destinies of the individual and of the race become so deeply merged that they are one and inseparable, and the modern philosophic dualism-the conflict between these two forces-vanishes as com- 
pletely as the vain argument over spirit versus matter.

In his poem The New World, Witter Bynner has voiced this conception of love in a way that no one else has ever done, and describes how the affection that broadens in its scope becomes at the same time more deeply and lastingly fixed upon the individual from whom it obtains its first impulsion.

"We stand together on our lake's edge, and the mystery

Of love has made us one, as day is made of night and night of day.

Aware of one identity

Within each other, we can say:

'I shall be everything you are.'

We are uplifted till we touch a star.

We know that overhead

Is nothing more austere, more starry, or more deep to understand

Than is our union, human hand in hand.

... But over our lake come strangers-a crowded launch, a lonely sailing boy.

A mile away a train bends by. In every car Strangers are travelling, each with particular And unkind preference like ours, with privacy Of understanding, with especial joy

Like ours. Celia, Celia, why should there be 
Distrust between ourselves and them, disunity?

... How careful we have been

To trim this little circle that we tread,

To set a bar

To stranger's and forbid them:-Are they not as we,

Our very likeness and our nearest kin,

How can we shut them ont and let stars in?

"She looked along the lake. And when I heard her speak,

The sun fell on the boy's white sail and her white cheek.

'I touch them all through you,' she said. 'I cannot know them now deeply and truly as my very own, except through you,

Except through one or two

Interpreters.

But not a moment stirs

Here between us, binding and interweaving us,

That does not bind these others to our care'

“'But, Celia, Celia, tell me what to be,'

I said, 'and what to do,

To keep your faith in me

To witness mine in you!'

"She answered, 'Dare to see

In every man and woman everywhere

The making of us two.

See none that we can spare

From the creation of our soul.

Swear to be whole. 
Let not your faith abate,

But establish it in persons and exalt it in the state.' ",

It is thus, through the clear intuitions of the woman's heart, as exemplified in Ellen Key, and through the inspired genius of the poet, guiding the pen of Witter Bynner, that we are able to formulate a final answer to the queries that the adolescent girl is making, and to give her an ideal of love that not all the friction of everyday life can cause to tarnish or grow dull. It is a conception which recognizes and includes the findings of the scientists and philosophers that have gone before, but it is much more than that. It is an interpretation which takes account of the instinctive needs of the organism, but does not fail to realize the paramount significance of those deeper longings of the human soul which have been engendered in the course of a long evolutionary process, which, although it may have had its beginnings in a mere chemical combination, is now not to be understood by any simple knowledge of biochemical laws.

Thus we are able to define love not as the mere physical attraction of one sex for the 
other,-although the importance of mutual desire as a factor in marital relationships must never be minimized,-but as the attraction of sex plus common interests and sympathies, which creates a happy and harmonious fusion of personalities into an organic whole. And the acid test which enables us to distinguish the true love from the false is whether its eagerness can be a transforming glow that enables us to feel that deep and abiding love of the human race which Nicolai says is the only real and worthy religious emotion, or whether it narrows our outlook so that we see the existence only of ourselves and one other.

The love which absorbs all the energies of the lover in ministering to the foibles of the loved one is not the love we need to-day. We need the love that renews and replenishes its energies in the love of its mate, to turn its forces outward again, into ever widening social and racial expressions. For this is the love that is eternal, the love that brings to its fortunate possessor the joy of fulfilment that is beyond all expectations, and at the same time carries 
out the great cosmic purpose for which it was created.

It is this great and ideal love which the girl of the present generation is coming to demand, and it will be even more insisted upon by the next generation. For as yet it is, for the most part, only slowly taking shape in the nebulæ of the unconscious soul of woman. Man is even slower to understand it, since he is more used to receiving than giving all in love, while woman has back of her a long history of vicarious fulfillment through her offspring, and is thus accustomed to entering into the life of others.

Meanwhile, the girl of to-day is experimenting vainly in the attempt to settle the vague unrest which this faint foreshadowing has set astir within her being, and is attempting to work out her problem by the costly method of trial and error. Only when her longing for the perfect union of body and mind, with its potentialities for unlimited projection into the life of mankind, is definitely formulated in her consciousness, and when man, too, has come to see her viewpoint, and is willing to do his share toward the realization of this new ideal of mar- 
riage, shall we see a cessation of all the anxiety and misgivings which now torture the minds of mankind in their quest for the perfect and abiding love.

\section{BIBLIOGRAPHY FOR CHAPTER VI}

1. Grant Allen. Falling in Love and Other Essays. 355 pp. Appleton. N. Y., 1890.

2. Bain, Alexander. Emotions and the Will. Pp. 605. Longmans. London, 1899.

3. Bell, W. Blair. The Sex Complex. 233 pp. Bailliere, Tindall \& Cox. London, 1916.

4. Bloch, Ivan (Eugen Duhren). Sexual Life of Our Time. 790 pp. Rebman. London, 1908.

5. Carpenter, Edward. Love's Coming of Age. 168 pp. Labour Press. Manchester, 1897.

6. Danville, Gaston. La Psychologie de l'Amour. 169 pp. Baillière. Paris, 1894.

7. Drummond, Henry. The Ascent of Man. Lowell Lectures. 346 pp. J. Pott \& Co. N. Y., 1894.

8. Finck, Henry T. Primitive Love and Love Stories. 851 pp. Seribner's. N. Y., 1899.

9. ㄴ. Romantic Love and Personal Beauty. Macmillan. N. Y., 1891.

10. Finot, Jean. Problems of the Sexes. 408 pp. Putnam's. N. Y., 1913.

11. Gallichan, Walter M. The Psychology of Marriage. P. 194. Laurie. London, 1918.

12. Geddes \& Thompson. Evolution of Sex. P. 322. Scribner's. N. Y., 1901.

13. Key, Ellen. Love and Marriage. 399 pp. Putnam. N. Y., 1911. 
14. Kropotkin, P. A. Mutual Aid. P. 348. Heinemann. London, 1902.

15. Mantegazza, Paolo. The Book of Love. 232 pp. Amer.-Neo-Latin Lib. N. Y., 1917.

16. Michelet, Jules. L'amour; Etude par Jules Lemaitre. 464 pp. Calmann-Lévy. Paris, 1859.

17. Pearson, Karl. The Grammar of Science. 3d Edit. P. Black. London, 1911.

18. Renooz, C. Psychologie Comparée de L'Homme et de La Femme. 576 pp. Bibliothèque de la Nouvelle Encyclopédie. Paris, 1895.

19. Ribot, Theodore. Psychology of the Emotions. 455 pp. Seribner's. N. Y., 1597.

20. Roux, Joauny. Psychologie de L'instinct Sexuel. 96 pp. Baillière et fils. Paris, 1899.

21. Schopenhaner, Arthur. The World as Will and Idea. 3 vols. Paul, Trench, Trübner \& Co. London, 1888.

22. Smith, Theodate L. Types of Adolescent Affection. Pp. 178-203. Ped. Sem. XI, 1904.

23. Sutherland, Alexander. Origin and Growth of the Moral Instinct. 2 vols. Longmans, Green \& Co. London and N. Y., 1 S9S.

24. Thomas, W. I. A Difference in the Metabolism of the Sexes. 63 pp. Reprint Am. J. Sociol. III, 1. Univ. Press. Chicago, July, 1897.

25. Weiniger, Otto. Sex and Character. 356 pp. Heinemann. London, 1906. 


\section{CHAPTER VII}

\section{THE ADOLESCENT GIRL AND HER FUTURE}

Varied rôle of woman in the social life during the war; Effect of the war on sex relations:-Raping of con- quered women, war brides, illegitimacy; Attitude of the American girl to the soldier; Results of this lowering of sexual morality on society and on the young girl; Effect of war on political status of woman; Position of woman in the social scheme;-Schoonmaker's conception, Kidd's vision of woman as the embodiment of love, Madeline Doty's summary of what she has done; Responsibility which rests upon the adolescent girl; New feminine art and literature needed; The religious belief of the adolescent girl:-Nicolai's interpretation of Christianity as a cosmic humanism.

If we are to discuss the possibilities which the future may hold for the adolescent girl with any degree of insight, we must first of all consider the effect which the far-reaching ramifications of the World War have had upon her present status, for it has touched her life at many points, and wrought changes in her personal life and in social conditions that bid fair 
to have a significant bearing upon her ultimate fate. In response to the call of her couritry's need, she entered every field of industry in all the warring nations, or, obedient to the larger voice of humanity, left the shelter of home to minister to the soldier, as he returned tired, hungry or wounded from the trenches. In Russia, she went forth to battle with the foe, not individually, but in a solid phalanx, nerved by the supreme will to save her country and her people from destruction, and borne up by an impersonal love of the fatherland which was even greater than her natural feminine aversion to inflicting bodily pain. $(2 ; 5$.)

It is in the field of sexual relationships that the war has wrought its greatest influence on the life of the adolescent girl, however, for in all its phases, it has tended to reduce the lovelife of humanity to its more primitive levels, and thus has retarded immeasurably the realization of the higher ideal of love which is the next logical step in the evolution of the race. The most brutalizing of the sexual tendencies which the war brought out was the raping of the women of the invaded countries. What this 
may mean in sheer mental anguish to the young girls thus cruelly awakened to the realities of life is poignantly expressed by Annie Vivanti Chartres in her book The Outrage, an authentic account of the sufferings of a typical Belgian family at the hands of the German invaders. (3.)

When the Germans entered their home, Louise, the young wife, and her sister Cheri were forced to endure the lascivious embrace of the enemy, while the little Mireille, lashed to a staircase, saw the brutal officer have his will with Cheri's unconscious body. True to Freudian laws, this precocious initiation into the mysteries of the procreative act inflicted a psychic trauma on Mireille's stricken mind, which resulted in an hysterical conversion downward so that she lost not only the ability to describe her horrible vision, but all power of speech.

Tortured by the sight of her speechless child, and frantic at the thought of meeting her husband witl the hated German stigma upon her body, Louise reaches a nervous condition which forces the physician to intervene between her and her harsh destiny. But Cheri, in whose mind there lingers no memory of that fateful night when everything became dark as she lay helpless in the arms of the enemy, is imbued with a virginal passion for motherhood which takes no heed of the fact that her child was conceived in violence, and bears the features of the hated foe. It is only when the people of the village see her with her babe 
in her arms, and she is subjected to public taunt and insult, that she realizes that there is no hope for a child born so far outside the pale, and determines to kill it and herself. At this tragic instant comes the climax of the story, the dramatic value of which is only equalled by its psychological interest.

It is midnight when Cheri reaches her decision as to the only course open to her tortured heart, and throwing a veil over her head, opens the door to leave the room wherein she has endured so much of agony. Thus veiled, with her child at her breast, and the crescent moon shining through the open window behind her, she bursts upon the startled gaze of Mireille, a celestial vision in place of the horrible scene which the child has expected to see reënacted before her eyes, just as it was seared into her memory that night a year ago.

Trembling at the miracle, Mireille seeks with all her will to utter the proper greeting, and after a space of interminable despair at her helplessness, the words come out at last,-_Ave Maria! Ave Maria!" So Mireille's mind is healed through the unhappy mother and her despised child.

All through the invaded territory of France and Belgium, these offspring of violence have entered upon a darkened life. And not only are their mothers compelled to bear the burden of this forced maternity; on the child, too, the sorrow falls. For even though an awakened 
society is removing the stigma of shame from these children, born outside the marriage bond, it is impossible to estimate the warping of the psychic and social life of a child reared, as these girls have sworn to rear their offspring, in hatred of their father and his race.

Scarcely less degrading in its effect was the war bride movement which swept over the European nations at the beginning of the war.

"Efforts were made in various nations (Germany, Great Britain, Austria, Turkey),"' says David Starr Jordan, "to guard against a falling birth rate by offering special inducements to marriage before leaving for the front. . . . I am told that in Berlin, in early August, 1914, more than 50,000 of such marriages were celebrated. A similar kind of war mating took place in many other military centers.'" ( $8: p$. 123.)

In the one-act play entitled "War Brides," Marion Craig Wentworth has presented a keen analysis of the varied reactions of adolescent girls to the governmental command encourag. ing marriages for repopulation purposes. (16.) 
The action centers around a young wife whose husband has been torn from her side at the beginning of the war, leaving her to bear their child in Ioneliness, amid the horrors of a fighting nation. Half crazed with grief, she opposes her feeble will to the mandate of the state and the rising tide of public sentiment which is lauding the splendid patriotism of these brides of a single night. Her seditious speeches bring the captain with orders for her arrest, but even as he arrives comes the news of her husband's death, and with the words, "Tell your emperor I will not bear my child to aid his cruel wars," the tortured girl shoots herself.

There are lines in the play which show very clearly the psychic forces back of the war bride demonstration. The influence of the mind of the crowd is clearly shown in the picture of Minna, who is happy in the possession of her iron wedding ring and in the cheering of the crowd; content to see her husband march away after the first passionate embrace because she is sustained by the thought that she is one of those patriotic heroines whose names will go down in history; in short, she is living up to the ideal of subordination to the state cleverly instilled into the people in the moment of their emotional crisis, and is happy in the feeling of 
social approval which is hers as a result of her marriage.

Mingled with this yielding up of the power of decision to the mob mind is the powerful attraction which now, even as in other days, the habiliments of the warrior possess. For just as the war-paint of the savage made him a thing of beauty to the cave woman who saw in this evidence of his manliness a source of protection for herself and her children, and just as the mediæval beauty gave her hand to the knight who bore her colors through the fiercest tourneys, so, from sheer force of age-old ancestral habit, the twentieth century girl turns eagerly to the man in khaki, enchanted at the prospect of once more having a soldier-husband. Thus, in reply to the accusation, "You married that loafer!' Minna replies, "But he may be a hero, now ; he is a soldier," as though the mere donning of the uniform were the long sought formula of the alchemists, which would change its wearer's nature from dross to shining gold.

The increase of illegitimate births in war time is due in part to the operation of similar 
psychic motives. Allied to the hero worship, to the love of manly power, which attracts woman to the fighting male, however, is a vast emotional tension which tends to break through conventionalities and outer restraints. The girl knows her lover will soon be facing danger and death, and all else pales into insignificance beside this agonizing realization. Moreover, the war mood, which Dr. Partridge describes, with its summation of the emotional life, is reflected in the civil population, and particularly in those who have intimate connections with the warring units.

On the one hand, this makes for the morale of the people who remain at home, so that they stand solidly behind their army, and will make every sacrifice in their power to support the soldiers they have sent to the front. On the other hand, the nervous tension tends to break over into other chamels, as is evidenced by wild rumors set afloat in war time, and by various other abnormal occurrences. In the young girl, it is not strange that this summated emotion of the group tends to reinforce the love-life, so that she feels no other desire than the supreme 
one to express her whole affection now, before it becomes too late. Beside this grand emotion, all other motives pale into insignificance, and with a fine disregard of consequences, and no thought of the personal suffering which her rashness may entail, she casts aside all thought of self, and gives herself wholly to the man she worships in proportion as she fears his loss.

The American girl showed this preference for the soldier as clearly as her European sister. All her conventions were thrown aside, and the soldier was greeted everywhere as though his uniform were a guarantee of his social and moral standing. More than one wedding was hastened by the bridegroom's entrance into the service, and many an engagement and marriage was entered into after the briefest acquaintance. The tendency did not assume the proportions that it did overseas, for it lacked the stamp of government sanction and the incentive of public approval. But the American girl, as shown by data loaned me by Dr. Iva L. Peters, ${ }^{*}$ has long worshipped the * See preface. 
athlete, the man of mental alertness and physical vigor, and blinded by the romantic glamour that surrounded the soldier in the tension of the war atmosphere, she saw her ideal suddenly come to life in him. So she rushed into a hectic love affair, borne on by the excitement and enthusiasm which permeated the group mind.

What will be the ultimate result of these hasty unions? The young bride, scarce awakened to the full maturity of womanhood by her brief marital life, will find the problem of adjustment to a husband little known at first, and still more strange since the experiences of war have changed and matured him, no light task. Again, as Ellen Key $(9 ; 10)$ and Artzibashef (1) have suggested, when war returns a wounded mate to the young wife, robbed of his physical vitality, what is to prevent her transference of her sexual emotions to some ablebodied man? Truly the outlook for happiness and for wifely constancy in these war marriages is a sad one!

The impulse to throw aside the restraints of conventional monogamy is everywhere encouraged and upheld by other conditions which have 
been brought about by the war. Appalled by the frightful loss of its young men, and fearful for the national future, the governments of the warring countries have determined to use every means in their power to counteract the falling birth rate which would be the natural result of this state of affairs. Schreiner (14) tells us that the stain of illegitimacy has been wiped out by the legal action of Germany, while from authentic sources comes the statement that imperial command made it a duty for the soldiers of that country to ensure the repopulation of specific districts allotted to their care.

Mrs. Deland (4) says : "If Germany officially approves the Torgas pamphlet on the plurality of wives-secondary marriages-France unofficially-but without public or legal disapproval -may read Mère Sans Épouse-a study of existing conditions written with dignity and solemnity."

The book to which Mrs. Deland refers advocates, as is indicated by the title, motherhood outside of marriage as a more noble and suitable solution of the problem France is facing than the institution of Polygamy. (15.) 
The same lowering of sexual restraints has, to be sure, followed every great war of history, but never before has it occurred on so large a scale, or been so publicly condoned and even encouraged. Everywhere, the doctrine is being spread broadcast that this war is to mark a radical change in the world's system of sexual morality. The Eugenists are raising their voices as never before, and are reiterating that it is the quality of the offspring, not the nature of its conception, that is the all-important thing: The logical outcome of this assumption is polygamy or unmarried motherhood, since the war has so drained the male stock of Europe that the maintenance of monogamy is incompatible with eugenic standards.

In America, where there is less necessity for the exploitation of such readjustments, since conditions have been less radically changed, these ideas are, nevertheless, having their undoubted influence on the public mind. For America is reading the books which have been written in defence of these measures for repopulation which rule out the higher conceptions of love between the sexes, and she knows 
that the nations with whom she has fought shoulder to shoulder, and for whom she has come to have the deepest regard, are adopting them, at least for the present. Moreover, the $3,000,000$ men whom she sent to France have come back with a viewpoint on these matters colored by the attitudes they have absorbed and the experiences they have undergone. And so, while she will not openly approve departures from the conventional moral code, America will, nevertheless, find an increasing number of her young people listening to these now doctrines of sexual liberty, and applying them to the problems of their own existence.

Unfortunately, it is doubtful if the adoption of these new standards would better the existent situation in any way. The mental anguish which any union other than a monogamous one must create in the woman's soul is infinite and inevitable; while the union which exists outside public sanction starts with a great handicap which must almost surely wreck its felicity. For upon the girl, in both instances, even under the broadening standards of the present day, falls the greater share of social disapproval, 
and the gregarious instinct is too deeply implanted within the human organism to endure suppression without evil effects. If a secret love avoids this social condemnation it has little more chance of survival, for the constant element of fear, and the impossibility of the natural fruit of marriage in children, will combine to make such a love die of its own stagnant and uncreative nature. Only in rare instances, such as occur once in a single age, can an unsanctioned and childless love become so productive in the artistic or intellectual realm that it more than compensates the possessors for all the sacrifices and anguish which it involves.

Even were these temporary unions uncriticized by the general public, it is doubtful whether the children resulting from them would reach the final goal of perfection optimistically expected by the enthusiasts who claim that these are the superior offspring, the eugenic stock. For this thought makes the old Platonic mistake of underestimating the value of the family situation in the life of the child, and forgets how necessary for the production of a normal personality is the background of a happy 
home and the possession of two parents by whom to shape the social reactions.

We are forced to the conclusion, therefore, that in so far as the war has affected the sexual relationships of the adolescent girl, it has worked incalculable injury in that it has deflected her attention from the new and high ideal of love which she had been slowly and painfully evolving, and set up false prophets for her guidance. But in a different sense, it has opened the way for a realization of her ultimate destinies in a way that centuries of peace could not have done. And the manner in which it has done this has been two-fold: first, it has led her out into the field of political affairs, and second, it has made man realize that perhaps, after all, his guidance of world affairs might not be made less steady by the touch of a woman's hand upon the rudder.

It is a happy coincidence that just when the fortunes of war have brought woman into the political life of the world, there should at the same time be formulated an expression of the crying need for her presence in the ordering of world affairs. Now, in 1919, the women of 
Russia and Germany have full rights of citizenship with the men, while in England they are given the franchise after they have attained the age of thirty years. In our own country, the states are ratifying the constitutional amendment for equal suffrage. In France, to be sure, the war has not brought franchise privileges to the toiling and enduring women who have held the internal life of the nation intact while the husbands, sons and brothers kept the enemy from overrumning the land, but even there it has awakened the feminine soul to the fact that she must have a direct voice in the national life.

As early as 1915, Schoonmaker had dimly sensed the need of woman's presence in the councils of those who possessed an active voice in the destinies of society. (13.)

The argument that the participation of woman in the affairs of society would work injury has received its death blow. What was it in woman that we feared -the softening of society? On this score the war has indeed reassured us. Indeed, woman may well inquire why she should leave her home and come into a world that has no appreciation of her purity and virgin emotion. Will it ever be possible for woman 
again to bring forth a child and question not if her pains were worth while? Never since the beginning of time has life's appalling contradiction so torn the heart of woman as to-day. Never again can woman remain ealmly at home, in the thought that the world's affairs are outside her sphere. For to-day the affairs of the world are wrecking the homes of the earth, and woman realizes that if she would keep her home inviolate, she must bear her share of the affairs of the body politic.

The sudden murder-lust which has sprung up in the soul of man is but a continuation of the fierce economic competition, with capital mercilessly crushing labor to the earth. In both cases, the fundamental trouble with society is the separation of power and love in the body politic, which is due to giving over social control to power-desiring man, and denying expression to the love-nature of woman in the affairs of the world. Humanity is crying up to the skies for love, while the heart of woman is yearning to the world.

In the final analysis, this war is a demonstration by nature of the utter futility of the separation of love and power in the building of the world. The problem is, what will be the lot of the future? Woman is being forced into public industries and affairs by the events of the war as never before. Will she remain there, or will she willingly surrender her enlarged field of activity to her partner on his return from the field of battle? Perhaps we can find some prophecy in history which will throw light on this subject. After 
the crusades, man did not settle back into his old narrow life circumscribed by the cirele drawn by churchly dogma; on the contrary, his spirit, thrilled by his adventure, blossomed out in the Renaissance.

Even had not the spirit of woman been thus kindled, the tremendous slaughter of men in Europe will necessitate her remaining in industry to a very great extent. What will she do with this new opportunity? Will she be content with her new freedom, and settle down to simple mastery of her new tools? Or will she realize that the end is not yet? Will she attain the higher vision, and see that her real service lies not so much in labor as in those higher spheres of control? Will she understand that to give peace and justice to the stricken world, love must sit beside power willing and able to intervene whenever necessary? Or in her inevitable struggle to reach this high place, will she forget her great cosmic mission, and hardened by the conflict become a second male, simply another unit of power? Will the homemaker of the centuries lose her vision, and forget that the divine purpose of her coming is to make of the world a home?

In a still broader way, Benjamin Kidd, in his book entitled Science and Power, outlines the social need for woman. (11.)

Man is a fighting pagan, a destructive force in the world. Woman, on the other hand, through centuries of subordination of self and present interests to those of the race and of the future, is the ultimate guide 
to whom we must turn in our efforts at social reconstruction. Her psychic power has remained unutilized in the field of civic and public life, but hers is the needed trait,-altruism and sacrifice of self for the group welfare. Where the fighting male has set up ruthless efficiency, whether in economic competition or in war, she will look to the good of the race, and hold up forbearance and the ideal of the general welfare and happiness.

"The driving principle in woman's nature at all its highest levels has been by pure physiological necessity the subjugation of the present, with all its imperious demands to a meaning beyond herself and beyond all intercsts visible in the present. By the necessities of evolution ... woman has ever been the creature of the long-range emotions through which the instant needs of the present are subordinated to the meaning implicit in the long series of cause and effect through which maximum power expresses itself in the social integration." (P. 201.)

The mind of man has ereated for the world an ideal social self as his model based on the principle of force and selfishness. Man always strives to attain this ideal as it is set up for him in literature, and in various other expressions, and thus it becomes necessary for woman to create the social ideal of the future, to endow it with her characteristics of self-sacrifice and service in following the emotion of the ideal, that man's forcefulness may also be turned to this channel, and have at last a worthy goal. The peoples who seek their guiding principles in this psychic trait of 
the mind of woman will be the winning people of the world of the future.

Madeline Doty (6) has given us a concrete report of how woman has risen to the ideal which these two men have set up for her in the short time thus far elapsed.

The horrors of the Bolsheviki would be tenfold except for the women of Russia, who have fought, and worked, and gone into exile in the long struggle to bring about the revolution, and are now exerting all their powers to restrain the brute force of the men, and to inculcate the quality of mercy into their dealings. In Sweden and Germany the Feminist movement has centered around the child, and the protection of motherhood. The French women have been the bulwark behind the war; it has been their spirit, their loyalty, which has enabled the men to go to the front secure in the knowledge that the essential industries would be carried on in their absence. In England, it is the eugenic needs which are woman's first concern, and the problems of industry that affect the welfare of the workers and of the next generation.

The woman of the present generation has accomplished much. She has made man realize that he has need of her in his great business of managing the world, and she has not failed to attack the political problems which lie within 
her sphere. But the woman of to-morrow is called to yet higher tasks, for to her is given the mission. of shaping the social ideals and aspirations into the service of love, as well as of power. "The hope of the future lies in the release of the woman spirit, so that henceforth masculinism and feminism can combine to make one great spirit of humanism.',

Whether woman can accomplish this mighty miracle depends in large measure upon the manner in which she emerges from the adolescent crisis, for if she is to be successful in making the love ideal an integral part of the world mind, she must first be certain of its supremaey in her own nature. So, not only for the sake of her own personal happiness, but for the welfare of all humanity, the girl of today must achieve the subordination of the egoistie sentiments to the racial and altruistic emotions which are the truly feminine psychic traits. And she must also achieve the ability to sublimate these energies and project them into the life of humanity, whether she accomplish this purpose by means of intellectual and social work alone, or through bringing man to 
understand and accept the new ideal of love, with its all-embracing character, which is the next step in the psychic evolution of mankind.

The franchise is, however, only one small means to this great end. Not only must woman use her new political power to set up the love ideal in the hearts of mankind, she must also give to her social philosophy an expression in literature and art. The women of Sweden have already taken the first steps in this direction; it remains for the talented women of other nations to break away from slavish imitation of masculine forms of expression, and to become truly creative as th y release their own personalities and embody their own aspirations. The social philosophy of Ellen Key, which is the projection of the mother spirit into the life of the whole race, and the literary genius of Selma Lagerlöf, which weaves the same motif into a more imaginative form, are the beginnings of the attempt to make articulate the very life and soul of womanhood. It is because these women have created their work from within their own inner life, and have not wrought dully after man-made patterns, that 
they are recognized among the great ones of the age. Here, too, it is in the giving of herself over to the organic impulses of the race, and in finding a sublimated expression of them, that woman reaches the highest realization of her own individuality.

But the final expression of the woman spirit will be the new religious conception which it is fitting that she should give to the world. For to woman is entrusted the first religious instruction of the child, so that it is essential that she should conceive and pass on to the childhood of the race a new interpretation of Christianity, which shall inderd be a religion of brotherly love. Because she has ever been less bound by creed and dogma than man; because it has been the spirit and not the letter that has appealed to her in all her worship; because with her religion has always been a thing of the emotions, it should be easy for her to understand the new conception of Christianity which would sweep away all differences of sects, and unite mankind in one great universal idealism.

The adolescent girl, with her innate need of religious emotion as a sublimation of her erotic 
life, with her native tendency to conversion and consecration to some high and mystical ideal, is the one to whom, in all its inspiring scope and breadth of vision, this new religion should be given, first of all. Every sign points to her acceptation of this fuller and richer version of Christianity, for she is newly thrilled with the love of her fellow-beings, and keenly responsive to the beauties of the earth and to the forces of nature. Hence the great cosmic interpretation, which sees the universe as one organic whole, and man as an integral part of all existence, satisfies her emotional cravings at the same time that it answers the intellectual doubts of churchly dogma which have begun to trouble her mind.

In this far-reaching vision, the evolutionary doctrine, which seemed to narrow minds incompatible with the worship of Jesus, in reality makes him and his teachings vital as it shows the rationality of the doctrine of brotherhood which he set forth.

" 'Our Father' is merely an expression of my filial relation to the great one and all from which my own being was derived through the 


\section{THE ADOLESCENT GIRL}

long processes of evolution. I am a son of the sky and the nebulx; thence I came and into them I shall be resolved. . . . This conception makes us realize that we are relatives not only of plant and animal life, but of rocks, soil, sea, air; brothers of every element; that all are our kin, for we have the same parent,-the primordial force out of which the world arose." ( $E d$. Prob. p. 139-140.)

So says G. Stanley Hall, and in the light of this statement it becomes apparent that Jesus was not simply stating an abstract ethical principle, but was expressing an inherent emotional attitude to mankind founded in this organic continuity of the universe and of human life, which makes men our brothers in a deeper sense than any system of moral injunctions imposed from without. And as we trace the evolution of life upon the earth from the first lowly protoplasmic unit to the complex and highly organized human species, we cannot but feel that this slowly evolved being is more worthy of our love than any creature molded from dull clay, and infused with the breath of life in a single 
instant, as a literal interpretation of the biblical story of creation implies.

In this evolutionary doctrine, which shows man as the final product of æons of infinitely slow development, there is implicit a great and glorious hope for the future which far outshines any anticipation of individual immortality. It is an expectation based on certainties, rather than on vague wishes and the blind faith that they will come true; because we know that the great energy of life,-the Bergsonian élan vital, -will push the race onward, slowly and irresistibly, long after our little day, even as it did in all the ages that were a preparation for our coming. Thus, in so far as we can consciously make our life count ever so little in the realization of this change, whether by the production of better offspring, or by intellectual or social work which shall make the way swifter for those who are to come, we feel ourselves one with this great cosmic purpose, and are experiencing as soul-satisfying an emotion as did th mediæval mystic in his ascetic contemplation and union with God.

It becomes evident, that the sonship of Jesus 
was not a sonship to the Deity of the Old Testament, but to the whole life of the stirp that had gone before, and in so far as he felt himself a link in the illimitable series of the future, and thus a part of the great cosmic forces, he was inspired with a sense of his own divinity. It was not necessary that he should know the doctrine of evolution, for his conviction was a more primeval one, instinctive and emotional, but as unerringly true as the rationalized belief of the modern scientist. And so, if we would truly follow the spirit of his teachings, we must set up for ourselves a new God,-the God Humanity, conceived as an organic whole, from the earliest beginnings of life through the present, and into the vast stretches of the future.

"If it were desired to found a religion which is, so to speak, unchangeable in its eternal youth and yet capable of modification so as to meet the needs of mankind, then it must be based on something unchangeable and yet capable of thange. . . ." Thus Nicolai, as he charges that all religions have failed, else man would not still be killing man. "Humanity," he continues, "is sufficiently absolute and mutable for 
our purposes. Moreover, it also rises above man and is yet human. Humanity has evolved and is evolving still further, in a course and direction which may be changing, but has been fixed once for all. We were animals, and we became human beings, and the human being of to-morrow is something different from the human being of to-day. . . The natural result of this ever-changing human reality, which in course of time becomes ever more and more perfect, is that the future will seem to us an ever higher reality, in which we can believe, on which we can legitimately set our affections, and to which we must pin our hopes.

"The three cardinal virtues of Christianity are in truth the main supports of religion; but we must not believe in anything unreal, nor set our affections on anything past, or our hopes on any mere visions. . . . To be humane simply means that we have comprehended the history of the evolution of mankind; that we know whence we come; that we have an inkling of whither we are going; and that we accordingly try to conform to the general scheme of nature, which for us means the new progress of human 
evolution. We believe in this progress of evolution; we love mankind, and we hope for further progress." (1:: pp. 549-552.)

It was this religion of humanity which Christ felt, and it is for us to realize that it is the only true interpretation of his spirit. And it is this religious conception alone which can satisfy the needs of the adolescent girl, for it permits her to worship the Christ-hero, at the same time that it fulfills her intellectual and emotional demands. And as she becomes mother and teacher, it is this view which she must pass on to the generations to come, so that man may transmute his fighting impulses into war with the forces of nature, in order to bring them still further under his control for the benefit of the race, and so that woman, herself, may find in this all-embracing love the supreme expression of her deepest nature.

\section{BIBLIOGRAPHY FOR CHAPTER VII}

1. Artzibashef, Michael. War. 122 pp. Richards. London, 1918.

2. Beatty, Bessie. The Red Heart of Russia. 480 pp. Century Co. N. Y., 1918. 
3. Chartres, Annie Vivanti. The Outrage. 261 pp. Knopf. N. Y., 1918.

4. Deland, Margaret. Beads: War-time Reflections in Paris. Pp. 169-177. Harper's. July, 1918.

5. Dorr, Rheta Childe. Inside the Russian Revolution. 243 pp. Macmillan. N. Y., 1917.

6. Doty, Madeline Z. Behind the Battle Line. $200 \mathrm{pp}$. Macmillan. N. Y., 1918.

7. Ellis, Havelock. Essays in Wartime. 247 pp. Constable. London, 1916.

8. Jordan, David Starr. War and the Breed. $265 \mathrm{pp}$. Beacon Press. Boston, 1915.

9. Key, Ellen. War and the Sexes. 837-844 pp. Atlantic Mo. V. 117.

10. War, Peace and the Future. $271 \mathrm{pp}$. Putnam. N. Y., 1916.

11. Kidd, Benjamin. The Science of Power. $306 \mathrm{pp}$. Methuen. London, 1918.

12. Nicolai, G. F. The Biology of War. 553 pp. Century. N. Y., 1918.

13. Schoonmaker, Edward D. The World Storm and Beyond. $249 \mathrm{pp}$. Century Co. N. Y., 1915.

14. Schreiner, Geo. A. The Iron Ration. 386 pp. Harper's. N. Y., 1918.

15. Torina, Martinde. Mère Sans Etre Epousé. 145 pp. Chez L'Auteur. Paris, 1917.

16. Wentworth, Marion Craig. War Brides. P. $527 \& \mathrm{ff}$. Century. V. 67, 1914-15. 

University of California SOUTHERN REGIONAL LIBRARY FACILITY 305 De Nave Drive - Parking Lot 17 - Box 951388 LOS ANGELES, CALIFORNIA 90095-1388 Return this material to the library from which it was borrowed. 
UC SUUIHERN REGIONAL LIBRARY FACILITY

AA 0010476364 
